\title{
FISIOLOGIA PÓS-COLHEITA DE GOIABAS 'PEDRO SATO': ESTÁdIOS DE MATURAÇÃO E PADRÃO RESPIRATÓRIO
}

\author{
MARISA AZZOLINI
}

\author{
Dissertação apresentada à Escola Superior de \\ Agricultura "Luiz de Queiroz", Universidade de São \\ Paulo, para obtenção do título de Mestre em \\ Ciências, Área de Concentração: Fisiologia e \\ Bioquímica de Plantas.
}

PIRACICABA

Estado de São Paulo - Brasil

Novembro - 2002 


\section{FISIOLOGIA PÓS-COLHEITA DE GOIABAS 'PEDRO SATO': ESTÁDIOS DE MATURAÇÃO E PADRÃO RESPIRATÓRIO}

\section{MARISA AZZOLINI}

Engenheiro Agrônomo

Orientador: Prof. Dr. ANGELO PEDRO JACOMINO

Dissertação apresentada à Escola Superior de

Agricultura “Luiz de Queiroz”, Universidade de São

Paulo, para obtenção do título de Mestre em

Ciências, Área de Concentração: Fisiologia e

Bioquímica de Plantas.

PIRACICABA

Estado de São Paulo - Brasil

NOVEMBRO - 2002 
Dados Internacionais de Catalogação na Publicação (CIP) DIVISÃO DE BIBLIOTECA E DOCUMENTAÇÃO - ESALQ/USP

\author{
Azzolini, Marisa \\ Fisiologia pós-colheita de goiabas ‘Pedro Sa to' : estádios de \\ maturação e padrão respiratório / Marisa Azzolini. - - Piracicaba, 2002. \\ 100 p. : il. \\ Dissertação (mestrado) - - Escola Superior de Agricultura Luiz de \\ Queiroz, 2002. \\ Bibliografia. \\ 1. Etileno 2. Fisiologia vegetal 3. Goiaba 4. Maturação vegetal 5. \\ Pós-colheita 6. Respiração vegetall. Título \\ CDD 634.421
}

"Permitida a cópia total ou parcial deste documento, desde que citada a fonte - $\mathrm{O}$ autor" 
Aos meus pais,

\section{Erminia Frozza Azzolini e Danillo Azzolini}

Que em meio a tantas dificuldades

tiveram amor, coragem,

persistência e sabedoria

permitindo, sempre, que eu seguisse em frente

DEDICO. 


\section{AGRADECIMENTOS}

A Deus, por estar sempre ao meu lado guiando e protegendo cada dia de minha vida.

À Escola Superior de Agricultura "Luiz de Queiroz", Universidade de São Paulo, pela possibilidade de realização deste curso.

A Val Frutas, em particular ao Eng $^{\circ} \cdot$ Agr $^{\circ}$. Ricardo Vendramini Rossi pela atenção e fornecimento dos frutos.

Ao CNPq, pela concessão da bolsa de estudo.

Ao Prof. Dr. Angelo Pedro Jacomino, pela excelente orientação, amizade, companheirismo e confiança em mim depositada durante a realização deste trabalho.

À Prof ${ }^{\mathrm{a}}$. Dr ${ }^{\mathrm{a}}$. Marlene A. Schiavinato, pela utilização do cromatógrafo e pela ajuda incansável durante a realização das análises de etileno.

Ao Prof. Dr. Ricardo Alfredo Kluge, pela amizade, discussões e sugestões feitas na realização do trabalho.

Ao professores Dr. Murilo de Melo e Dr. Luiz Antonio Gallo, pela utilização dos laboratórios.

À Prof ${ }^{\mathrm{a}}$. Dr ${ }^{\mathrm{a}}$. Beatriz Apezzato-da-Glória apoio prestado neste período.

À Prof ${ }^{a}$. Dr ${ }^{a}$. Marta H. F. Spoto pelo auxílio na realização da análise sensorial.

Ao Prof. Dr. Lázaro Eustaquio Pereira Perez, pela amizade e sugestões durante a realização deste trabalho.

Ao Prof. Agenor Maccari Junior por incentivar-me a pesquisa durante a graduação.

Aos funcionários do Departamento de Produção Vegetal, que das mais diversas maneiras colaboraram para realização desta dissertação. 
Aos funcionários do Departamento de Ciências Biológicas especialmente a Maria Solizete Graziol Silva.

Aos colegas e amigos Joane, Liliane, Carol, Amanda, Amaral, Silvana, Sílvio, Rogério, Daniela, Rafael, pelo convívio e apoio neste período. Em especial a Maria Cecília, Eliane e Flávia pela intensa ajuda em noites e domingos de laboratório!

Aos integrantes do grupo pós-colheita, em especial a Renata e Ana Luiza pelo auxílio na realização das análises.

A Geni e Karina pelo excelente convívio que vai deixar saudades, Fasti!

A Ilana por estar sempre disposta a ajudar, discutir, sugerir, ouvir e rir, mesmo após horas de intenso trabalho. Valeu, 'amiga-lhes'!

Aos meus nove irmãos e seis cunhados pelo suporte financeiro e apoio emocional durante esta caminhada, e aos 12 sobrinhos que sempre me deram alegria e o título de tia! Valeu grande família!

E por fim, agradeço com imenso carinho àquele que mesmo distante nunca esteve ausente, mesmo tão longe nunca deixou de ajudar e compreender estando sempre na mesma órbita. A você, Jean Paolo Gomes Minella, toda minha alegria! 


\section{SUMÁRIO}

Página

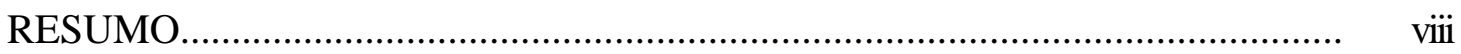

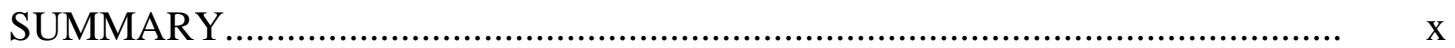

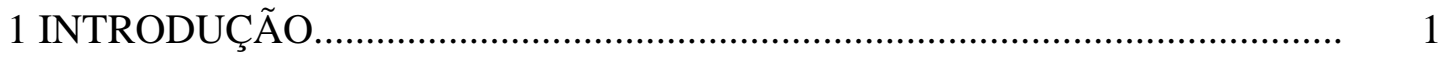

2 REVISÃO DE LITERATURA................................................................. 3

2.1 Perdas pós-colheita.................................................................................... 3

2.2 Desenvolvimento de frutos...................................................................

2.3 Fisiologia do amadurecimento e pós-colheita de frutos.................................. 5

2.3.1 Controle do amadurecimento.................................................................... 5

2.3.2 Respiração...................................................................................... 6

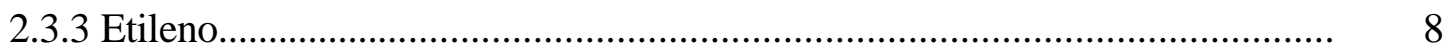

2.3.4 Relação entre a respiração climatérica e o etileno......................................... 12

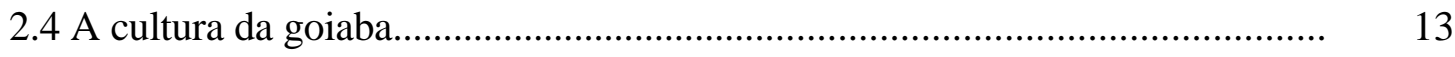

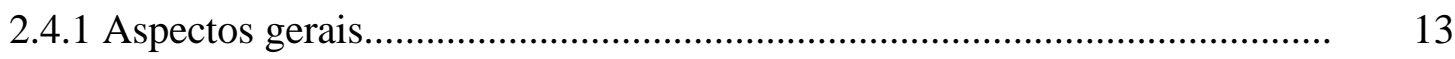

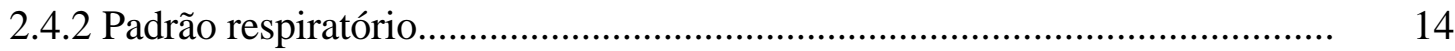

2.4.3 Estádios de maturação, ponto de colheita e qualidade do fruto...................... 15

2.4.3.1 Índices de maturação.............................................................................. 16

3 ÍNDICES DE MATURAÇÃO E INFLUÊNCIA DO ESTÁDIO DE

MATURAÇÃO NA QUALIDADE PÓS-COLHEITA DE GOIABAS

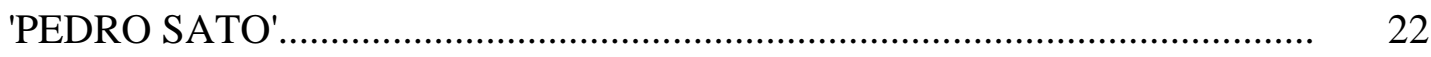

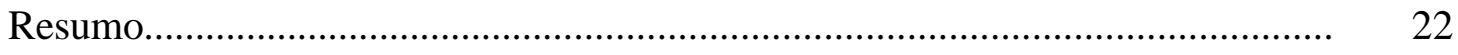

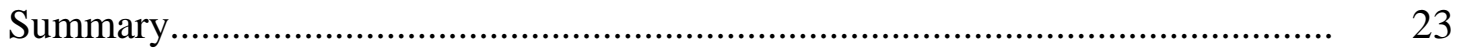




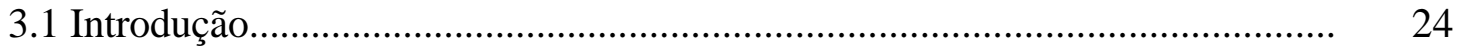

3.2 Material e Métodos.................................................................................... 25

3.3 Resultados e discussão................................................................................ 31

3.3.1 Caracterização dos estádios de maturação...................................................... 31

3.3.2 Mudanças físico-químicas em goiabas 'Pedro Sato' colhidas em três estádios de maturação.................................................................................. 34

3.3.3 Influência do estádio de maturação na qualidade pós-colheita de goiabas 'Pedro Sato'................................................................................ 38

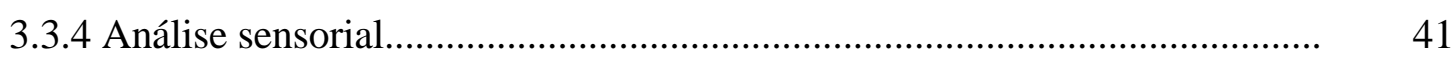

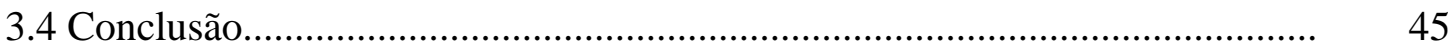

4 PADRÀO RESPIRATÓRIO DE GOIABAS 'PEDRO SATO'............................. 46

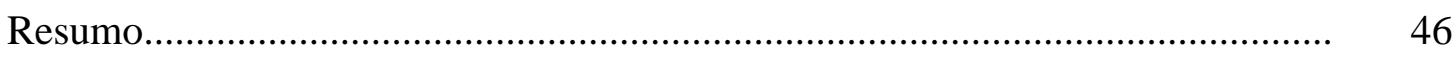

Summary

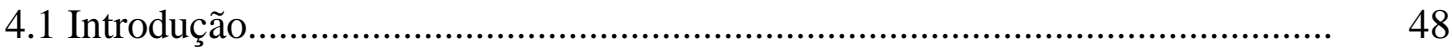

4.2 Material e Métodos................................................................................... 50

4.2.1 Experimento I...................................................................................

4.2.2 Experimento II.................................................................................

4.3 Resultados e discussão..............................................................................

4.3.1 Experimento I......................................................................................

4.3.1.1 Atividade respiratória e produção de etileno................................................. 55

4.3.1.2 Transformações físico-químicas e a relação com a produção de

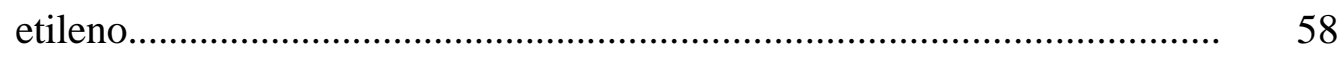

4.3.2 Experimento II...................................................................................

4.3.2.1 Resposta à aplicação de etileno exógeno e ao 1-MCP (1-metilciclopropreno).............................................................................. 72

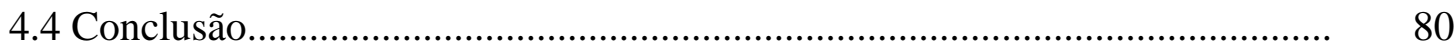

5 Consideração Final.....................................................................................

REFERÊNCIAS BIBLIOGRÁFICAS............................................................ 82

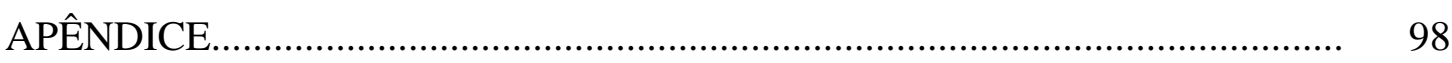




\section{FISIOLOGIA PÓS-COLHEITA DE GOIABAS 'PEDRO SATO’: ESTÁdIOS DE MATURAÇÃO E PADRÃO RESPIRATÓRIO}

Autora: MARISA AZZOLINI

Orientador: Prof. Dr. ANGELO PEDRO JACOMINO

\section{RESUMO}

A goiaba apresenta elevado grau de perecibilidade necessitando de um manejo póscolheita eficiente capaz de reduzir os processos de senescência. Para tanto, o conhecimento do padrão respiratório e dos processos envolvidos no amadurecimento é fundamental. O presente trabalho foi realizado com os objetivos de determinar os índices de maturação, a influência dos estádios de maturação na qualidade pós-colheita e o padrão respiratório de goiabas 'Pedro Sato' e avaliar as respostas dos frutos à aplicação do etileno exógeno e ao bloqueador da ação de etileno 1-MCP (1-metilciclopropeno). Na primeira fase determinaram-se os índices de maturação e a influência de três estádios de maturação na qualidade pós-colheita dos frutos. Os frutos foram selecionados em três estádios de maturação segundo a cor da casca: Estádio 1: cor da casca verde-escura; Estádio 2: cor da casca verde-clara; Estádio 3: cor da casca verde-amarela. Os frutos foram armazenados em câmara com temperatura controlada de $23 \pm 1^{\circ} \mathrm{C}$ e $85 \pm 5 \%$ UR e analisados quanto às mudanças físico-químicas e qualidade sensorial. Na segunda fase do trabalho foi determinado o padrão respiratório dos frutos analisando-se a atividade respiratória, a produção de etileno e as mudanças físico-químicas após a colheita. Analisou-se também a resposta dos frutos à aplicação de etileno $\left(1000 \mu 1.1^{-1}\right)$ e de 1 - 
metilciclopropeno (300nl. $\mathrm{I}^{-1}$ ) também foi avaliada. A cor da casca e a firmeza da polpa foram considerados os melhores índices de maturação. As variáveis físico-químicas apresentaram pouca variação entre os estádios de maturação durante o amadurecimento Porém, foram observadas diferenças significativas em relação à análise sensorial, sendo as melhores notas atribuídas ao estádio 3. Na segunda fase observou-se aumento da atividade respiratória e da produção de etileno independente do estádio de maturação, determinando o padrão climatérico de amadurecimento. Verificou-se que a máxima atividade respiratória e a produção de etileno ocorrem após o completo amadurecimento. Os frutos não responderam a aplicação de etileno exógeno, não apresentando diferenças no amadurecimento em relação aos frutos do tratamento controle. Entretanto, o 1-MCP retardou sensivelmente o processo de amadurecimento dos frutos. 


\section{POSTHARVEST PHYSIOLOGY OF GUAVA 'PEDRO SATO’: STAGES OF MATURATION AND RESPIRATORY PATTERN}

Author: MARISA AZZOLINI

Adviser: Prof.Dr. ANGELO PEDRO JACOMINO

\section{SUMMARY}

The guava presents high perecibilidade degree needing a handling efficient postharvest capable to reduce the senescence processes. Therefore, it is essential to the knowledge of the respiratory pattern and of the processes involved in the ripening. The present work was accomplished with the objectives of determining the maturation indexes, the influence of the maturation stage in the quality postharvest and the respiratoy pattern of guavas 'Pedro Sato' as well as evaluating the fruit response to the application of the exogenous ethylene and to blocking the action of ethylene 1-MCP (1metylcyclopropene). In the first phase it was determined the maturation indexes and the influence of three maturation stage in the quality postharvet of fruit. The guavas were selected in three maturation stages according to the color of the peel: Stage 1: dark green peel; Stage 2: light green peel; Stage 3: yellowish green peel. The fruit was stored in a chamber with controlled temperature of $23 \pm 1{ }^{\circ} \mathrm{C}$ and $85 \pm 5 \% \mathrm{RH}$ and analyzed for physicochemical changes and sensorial quality. In the second phase of the work the respiratory pattern of the fruit through the respiratory activity, the ethylene production, and the changes physicochemichal after harvesting. The fruit response to the aplication 


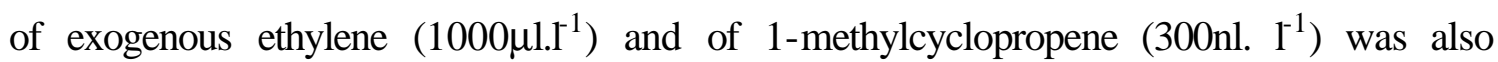
evaluated. The color of the peel and the firmness of the pulp were considered the best maturation indexes. The physicochemical variables presented little variation among the maturation stages during the ripening. However, significantive differences were observed concerning the sensorial analysis, being the best grades granted to stage 3 fruit. In the second phase the fruit presented increse in respiratory activity in production of ethylene independent at the maturation stage, determining the climacteric standard. The maximum respiratory activity and the ethylene production were verified after complete ripening. The guavas did not to responses the application of exogenous ethylene, showing no ripening difference respond in the ripening in relation to the guavas in the control treatment. However, the 1-MCP has sensibly retarded the ripening process in guavas. 


\section{INTRODUÇÃO}

Atualmente, há uma maior consciência das populações sobre a importância do consumo de alimentos saudáveis na prevenção de doenças e na melhoria da qualidade de vida. Isto tem resultado em um aumento mundial no consumo de frutas, que constituemse em um alimento de ótima qualidade. Este aumento é verificado pela crescente comercialização de frutas, principalmente tropicais, como manga, goiaba e mamão. A FAO (2001) estima que o consumo mundial de frutas tropicais aumente em $40 \%$ até 2005.

Entre as frutas tropicais, a goiaba (Psidium guajava L.) destaca-se por apresentar excelente qualidade nutricional, o que tem contribuído para o notável aumento do consumo in natura. O Brasil é um dos principais produtores desta fruta ao lado do Paquistão, México, Egito, Venezuela, Quênia, Porto Rico, Austrália e África do Sul. Entretanto, a participação do Brasil no mercado internacional é pequena. Em 2000 foram produzidas cerca 300 mil toneladas e somente $0,06 \%$ desta produção foi exportada (Choudbry et al., 2002).

As principais regiões produtoras do Brasil estão localizadas no estado de São Paulo e Pernambuco. No estado de São Paulo, as principais variedades produzidas para obtenção de frutas de mesa são: Kumagai, Pedro Sato e Sassaoka (Gutierrez et al., 2002).

A alta perecibilidade da goiaba é o principal problema enfrentado pelos produtores na comercialização da fruta in natura, tanto no mercado nacional, como internacional. A falta do emprego de tecnologias de conservação limita o período de comercialização e diminui a qualidade dos frutos, tendo por consequiência a redução do número de mercados consumidores. $\mathrm{O}$ incremento no consumo da goiaba como fruta 
fresca está condicionado a melhoria na qualidade dos futos. Desta forma, a aplicação de tecnologias de conservação pós-colheita são prioridades para a cultura.

O emprego de tecnologias eficientes de conservação é dependente do entendimento da fisiologia do fruto. Os conhecimentos a respeito da fisiologia póscolheita de goiaba, principalmente em relação às variedades nacionais, ainda são limitados. Questões fundamentais, como o comportamento respiratório dos frutos e a influência dos estádios de maturação na qualidade pós-colheita são pouco exploradas. Isto dificulta o estabelecimento de manejo adequado na pós-colheita. Desta forma, os objetivos deste trabalho foram:

- Determinar índices de maturação adequados para goiabas 'Pedro Sato';

- Verificar a influência dos estádios de maturação na qualidade pós-colheita de goiabas 'Pedro Sato', e

- Determinar o padrão respiratório desta variedade; 


\section{REVISÃO DE LITERATURA}

\subsection{Perdas pós-colheita}

A grande perda de frutas e hortaliças após a colheita é uma realidade, principalmente nos países em desenvolvimento, como o Brasil. O nível das perdas poderia ser reduzido se práticas corretas de cultivo, de colheita e principalmente póscolheita fossem adotadas. A falta de conhecimento dos processos fisiológicos dos frutos, a falta de infra-estrutura adequada e de uma logística de distribuição são os principais fatores responsáveis pelo elevado nível de perdas pós-colheita observados no Brasil.

O potencial de conservação de um fruto está diretamente relacionado, não só com o manejo adequado após a colheita, mas também, com as condições climáticas durante a produção e com as práticas culturais adotadas (Chitarra \& Chitarra, 1990).

Desta forma, a qualidade de um fruto é dependente da adoção de um conjunto de medidas que iniciam-se na formação do pomar e terminam com a distribuição do fruto no mercado consumidor.

\subsection{Desenvolvimento de frutos}

O desenvolvimento de um fruto pode ser dividido nas fases de crescimento, maturação, maturidade fisiológica, amadurecimento e senescência em função dos processos fisiológicos. Estas fases descrevem os diferentes processos desde a formação até a morte do órgão. Entretanto, muitos processos são comuns entre as fases, dificultando a clara distinção entre as mesmas (Watada et al., 1984), Figura 1. 


\section{Desenvolvimento}

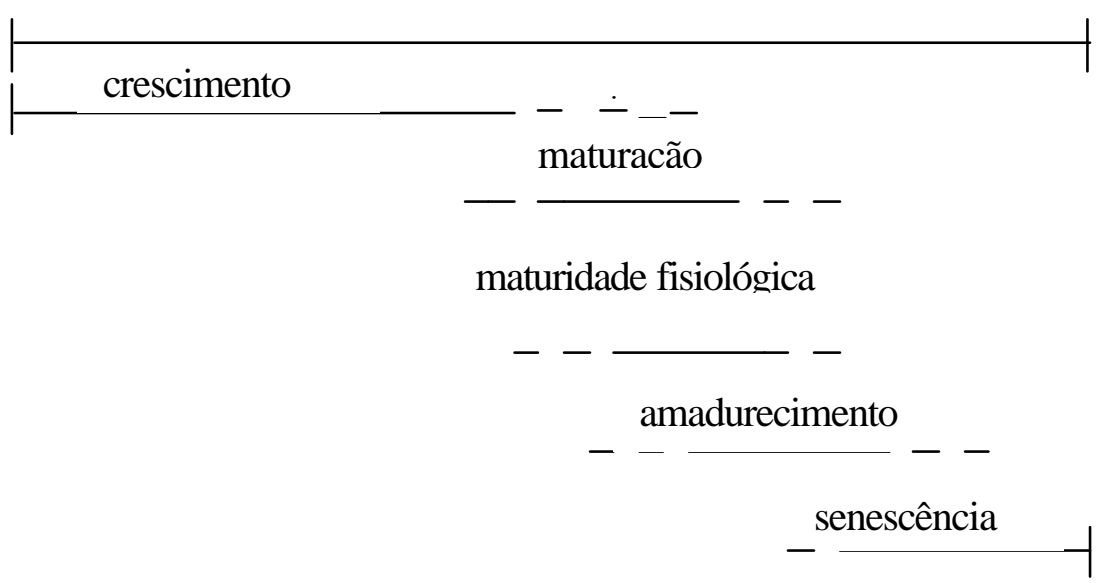

Figura 1- Fases do desenvolvimento baseado nos processos fisiológicos. (Modificado de Watada et al.,1984).

O crescimento é definido como a fase de desenvolvimento na qual ocorre o incremento irreversível nos atributos físicos; a maturação é o estádio do desenvolvimento que leva à maturação fisiológica e, a maturação fisiológica é definida como o estádio do desenvolvimento em que a fruta continuará sua ontogenia, mesmo que destacada da planta (Wills et al., 1998).

Em relação à fisiologia pós-colheita, o amadurecimento é uma fase importante do desenvolvimento dos frutos, pois torna-os palatáveis e comercialmente atrativos em função das mudanças na coloração, na textura, na concentração de açúcares e compostos aromáticos, bem como, na acidez e compostos fenólicos. Estas mudanças envolvem complexas transformações no metabolismo dos frutos, as quais são decorrentes do aumento da atividade enzimática, e no caso de frutos do tipo climatérico estão associadas à mudanças da atividade respiratória e biossíntese de etileno. $\mathrm{O}$ amadurecimento leva o fruto à senescência, fase final do processo de desenvolvimento (Rhodes, 1980; Vendrell \& Palomer ,1997). 
O estádio de maturação em que os frutos são colhidos é um fator determinante na qualidade pós-colheita. Segundo Castro \& Sigrist (1988), as condições do fruto na época da colheita determinam seu comportamento e, conseqüentemente, sua qualidade final. Frutos colhidos precocemente apresentam maior predisposição à desidratação e a distúrbios fisiológicos, podendo não amadurecer. Da mesma forma, frutos colhidos tardiamente apresentam um encurtamento do período de armazenamento, devido à aproximação da fase de senescência. Os frutos colhidos muito maduros apresentam rápida diminuição do sabor e aparecimento de podridão, que são sintomas típicos de frutos sobremaduros. Portanto, o estágio de desenvolvimento em que o fruto é colhido é o ponto inicial, dentro da cadeia de pós-colheita, para a manutenção da qualidade.

\subsection{Fisiologia do amadurecimento e pós-colheita de frutos}

\subsubsection{Controle do amadurecimento}

O amadurecimento de frutos foi inicialmente entendido como um processo exclusivamente catalítico, com perda do controle e da organização celular (Blackman \& Parija, 1928 ${ }^{1}$ ). Algumas décadas depois, estudos demonstraram que o amadurecimento e os processos de senescência estão sob estreito controle genético (Grierson, 1987; Giovannoni, 2001).

O amadurecimento, como todo o desenvolvimento vegetal, é regulado pelos fitohormônios. Os níveis e a sensibilidade de um tecido ou célula para um ou mais fitohormônios é função do estágio de desenvolvimento e de inúmeros fatores ambientais (Fluhr \& Mattoo, 1996).

O etileno, apesar de não ser o único fitohormônio a atuar no processo de amadurecimento, é considerado o principal fitohormônio desta fase (Abeles et al., 1994). A interação entre os fitohormônios promotores e inibidores é o fator controlador do amadurecimento. Segundo Vendrell \& Palomer (1997), o etileno e o ácido abscíssico,

\footnotetext{
${ }^{1}$ Citado por Seymour. Biochemestry of fruit ripening.(1993)
} 
podem ser considerados promotores, enquanto giberelinas e citocininas são possíveis inibidores do amadurecimento.

Após a colheita, a continuidade dos processos metabólicos é dependente das reservas acumuladas pelo fruto durante o desenvolvimento. $\mathrm{O}$ amadurecimento de frutos é geralmente acompanhado pela mobilização dos carboidratos e proteínas, sendo que a intensidade destes processos pode ser regulada pelas condições ambientais que o fruto é exposto, tais como temperatura e composição gasosa da atmosfera (Purvis, 1997).

\subsubsection{Respiração}

A respiração é o principal processo fisiológico que continua ocorrendo após a colheita. A respiração nos frutos segue as rotas metabólicas comuns em qualquer ecido vegetal: glicólise, ciclo dos ácidos tricarboxílicos e cadeia transportadora de elétrons. Estando associada também a via das pentoses fosfato. Os substratos da respiração em frutos são principalmente os açúcares, ácidos orgânicos e lipídios acumulados durante o desenvolvimento (Tucker, 1993). Durante a respiração estas substâncias são oxidadas em moléculas mais simples $\left(\mathrm{CO}_{2}\right.$ e $\left.\mathrm{O}_{2}\right)$, com produção de energia e esqueleto carbônico que podem ser utilizados em reações de síntese. A energia liberada está sob duas formas: calor e ATP (Wills et al.,1998).

$\mathrm{O}$ processo de respiração é fundamental no amadurecimento dos frutos, pois várias reações acopladas à respiração são responsáveis pela síntese de inúmeros compostos tais como: pigmentos, compostos fenólicos e fitohormônios (Purvis, 1997). Entretanto, a intensidade da respiração é um dos fatores determinantes na longevidade das frutas, em pós-colheita. A atividade respiratória provoca modificações profundas nos

constituintes químicos, principalmente em condições não controladas, levando à perda de umidade e à rápida senescência do fruto, interferindo assim, na qualidade do mesmo (Wills et al., 1981). 


\section{- Padrões de atividade respiratória}

A atividade respiratória é naturalmente variável entre as diferentes espécies e estágios de desenvolvimento dos frutos. Quanto ao padrão de atividade respiratória durante o amadurecimento, os fisiologistas têm dividido os frutos em 2 duas classes: climatéricos e não-climatéricos. São considerados frutos climatéricos aqueles que apresentam um aumento da atividade respiratória durante o amadurecimento, enquanto que frutos não-climatéricos são aqueles que o aumento da atividade respiratória durante o amadurecimento é ausente (Rhodes, 1980). Em geral, o amadurecimento climatérico é associado também ao aumento da produção de etileno. Para Lelièvre et al. (1997), frutos climatéricos, como tomate, banana, maçã e pêssego são distinguidos de frutos nãoclimatéricos como uva, morango, citros, pelo incremento na respiração e na produção de etileno durante o amadurecimento. Segundo Giovannoni (2001), em frutos climatéricos o etileno é necessário para coordenar e completar o amadurecimento.

Nos frutos não-climatéricos a respiração diminui durante o amadurecimento e as transformações bioquímicas que tornam o fruto maduro ocorrem de forma mais lenta. $\mathrm{O}$ amadurecimento só ocorre se o fruto estiver aderido a planta, diferentemente do frutos climatéricos que possuem a capacidade de amadurecer mesmo após a colheita (Wills, 1998).

O amadurecimento de frutos climatéricos apresenta duas fases distintas denominadas de fase pré-climatérica e fase climatérica. A taxa respiratória e as mudanças bioquímicas, bem como a biossíntese e a resposta do etileno diferem em cada fase (Oetiker, 1995). Na fase pré-climatérica níveis basais de respiração e de biossíntese de etileno são observados, os quais aumentam bruscamente durante o climatério e, posteriormente, na fase chamada pós-climatérica diminuem.

O padrão respiratório é um aspecto importante na definição do ponto de colheita. Os frutos climatéricos podem ser colhidos na maturidade fisiológica, já que estes continuam o amadurecimento após a colheita. Entretanto, os frutos não-climatéricos, devem ser colhidos quando atingem a completa qualidade comestível, uma vez que não completam o amadurecimento quando destacados da planta (Rhodes, 1980). 


\subsubsection{Etileno}

Os processos que envolvem a biossíntese e ação de etileno são complexos, e são dependentes de várias condições endógenas e exógenas do vegetal. O etileno pode promover diferentes respostas em função do estágio de desenvolvimento, das condições ambientais e da espécie ou mesmo da variedade (Lelivrieve, 1997).

As primeiras observações da capacidade do etileno em alterar o desenvolvimento dos vegetais foram feitas no século IXX. Os estudos tiveram grandes avanços em 1979 quando Adams e Yang descobriram o ACC (ácido 1-aminoacilciclopropano 1carboxílico) como sendo o precursor imediato do etileno, possibilitando a descrição da via biossintética (Taiz \& Zeiger, 1998).

O etileno é formado a partir do aminoácido metionina via SAM (S-adenosil Lmetionina). O SAM é convertido à ACC (ácido 1-aminoacilciclopropano 1-carboxílico) e este é subsequentemente oxidado a etileno. A conversão do SAM para ACC é catalizada pela enzima ACC sintase e a oxidação do ACC para etileno é dependente da ação da enzima ACC oxidase (Figura 2), (Taiz \& Zeiger, 1998).

O etileno é biologicamente ativo em quantidades traço e seus efeitos são comercialmente importantes na agricultura (Abeles, et al., 1992). As taxas de produção de etileno pelos tecidos são, geralmente, baixas. A concentração necessária para induzir o amadurecimento na fase pré-climatéria é dependente da espécie e estádio de maturação dos frutos. A banana, por exemplo, necessita apenas $0.1 \mu 1.1^{-1}$, enquanto para o melão a dose de etileno necessária para induzir o amadurecimento é de $3 \mu 1.1^{-1}$ (Yang, 1985).

É bem relatado que o etileno intervém, ao nível molecular, na indução da expressão de numerosos genes, incluindo os genes que codificam as enzimas celulase, $\beta$ 1,3 glucanase, peroxidase e proteínas ligadas a defesa contra patógenos. A expressão dos genes, durante o amadurecimento, parece ser regulada por 2 caminhos: um etilenodependente e outro etileno-independente. Genes envolvidos com a biossíntese de licopeno, aroma e metabolismo respiratório são considerados dependentes da biossíntese de etileno. Entretanto, em algumas espécies, genes que codificam a enzima clorofilase e ACC oxidase parecem ser independentes de etileno (Taiz \& Zeiger, 1998). Em frutos 
climatéricos o etileno promove aumento da biossíntese das enzimas da sua própria rota metabólica, caracterizando a produção autocatalítica.

Ação do etileno é dependente da sua ligação a um receptor. Recentes estudos em Arabidopsis têm demonstrado que este receptor possivelmente seja um complexo enzimático designado ETR1 (Fluhr \& Mattoo, 1996). É aceitável, afirmar que o etileno liga-se a este receptor, localizado na membrana celular, formando um complexo ativado que desencadeia um processo de reação em cascata. Estas reações levam à modificação da expressão gênica, com conseqüentes repostas fisiológicas e bioquímicas (Leliévre, 1997).

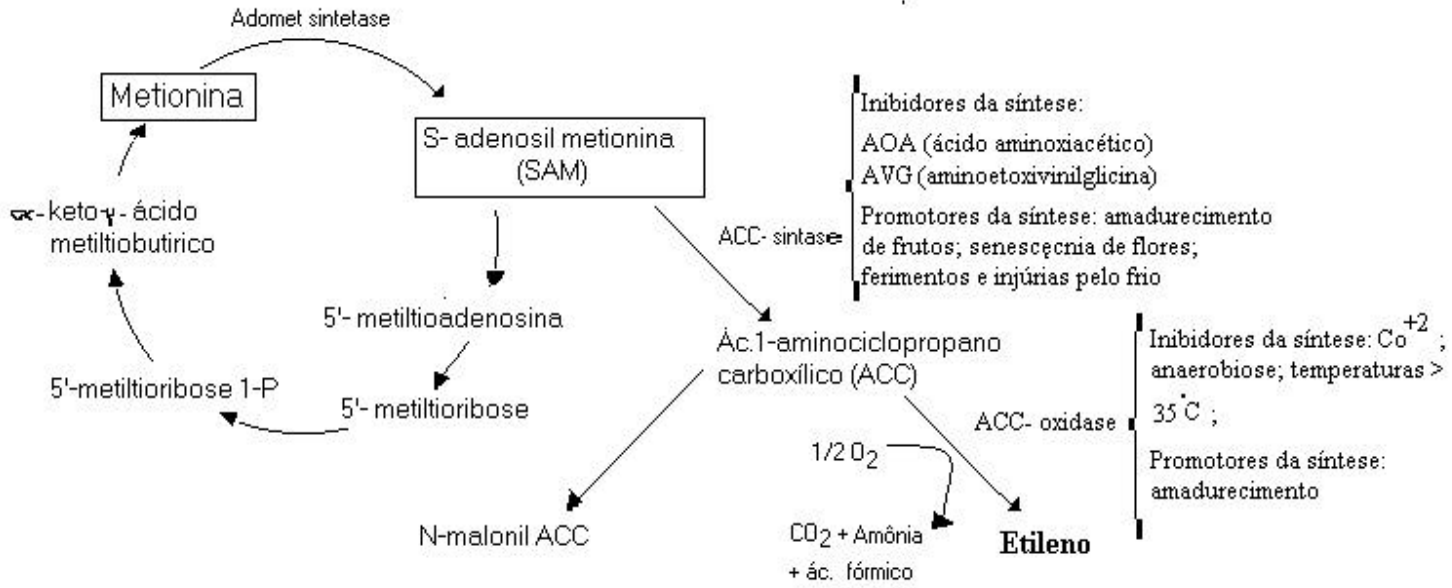

Figura 2- Esquema da via biossintética do etileno. (Modificado de Taiz \& Zeiger, 1998).

O controle da ação e da biossíntese de etileno é feito de várias formas, sendo uma prática comum na pós-colheita, que tem como objetivo o prolongamento da vida do vegetal. Atmosferas modificadas com baixos teores de $\mathrm{O}_{2}$ e altos teores de $\mathrm{CO}_{2}$, baixas temperaturas são técnicas usadas em pós-colheita para diminuir a biossíntese de etileno. A biossíntese de etileno pode também ser inibida pela aplicação de compostos como AVG (aminoetoxivinilglicia) e o AOA (ácido aminoxiacético), ambos inibem a ação da enzima ACC sintase, responsável pela conversão do SAM para ACC (Yang, 1985; Kanellis et al. 1991; John, 1997). 
A ação do etileno pode ser bloqueada pela utilização de compostos que atuam nos sítios receptores de etileno presentes nas membranas celulares. Os dois compostos mais conhecidos são o tiosulfato de prata e 1-MCP (1-metilciclopropreno), ambos possuem a capacidade de ligar-se aos sítios receptores impedindo a ligação do etileno e consequentemente sua ação. O 1-MCP foi recentemente descoberto e vem sendo amplamente testado para utilização em pós-colheita. Este composto liga-se de modo irreversível aos receptores de etileno impedindo sua ação e consequentemente bloqueando as reações do amadurecimento dependentes de etileno (Serek et al., 1994).

\section{- Etileno e os padrões de amadurecimento}

O aumento da biossíntese de etileno durante o climatério é considerado o fator responsável pelo início do amadurecimento em frutos climatéricos (Biale, 1964; McGlasson, 1985; Grierson, 1987; Abeles et al., 1994; Oetiker,1995).

McMurchie et al. (1972), distinguiram dois sistemas de produção de etileno (sistema I e sistema II), os quais estão associados com a fase pré-climatérica e climatérica. O sistema I é responsável pelos baixos níveis de produção de etileno presente no pré-climatérico e na produção de etileno dos tecidos vegetativos e frutos não-climatéricos (Knee, 1985; Oetiker \& Yang, 1995; Abeles et al. 1994).

A fase pré-climatérica pode ser reduzida com a aplicação de etileno exógeno acelerando assim o amadurecimento dos frutos, como também, pode ser prolongada pela aplicação de inibidores da biossíntese de etileno como aminoetoxivinilglicina (AVG) (Yang, 1985). Estudos relacionados com as enzimas, envolvidas na biossíntese de etileno, na fase pré-climatérica, revelaram que a ACC sintase não é induzida por curtos tratamentos com etileno, ao contrário da ACC oxidase, que é fortemente induzida (Yang et al., 1986; Oiteker \& Yang, 1995).

A fase climatérica é decorrente do sistema II da biossíntese de etileno, no qual ocorre a produção autocatalítica. $\mathrm{O}$ aumento da produção autocatalítica de etileno se deve ao aumento da atividade da ACC sintase (Vendrell \& Palomer, 1997). Esta enzima 
apresenta um tempo de vida muito curto, sendo um importante fator no controle da biossíntese de etileno ao nível de transcrição (Kim \& Yang, 1992).

Os fatores que controlam a transição entre os sistemas I e II não estão totalmente entendidos e parecem estar sob controle de aspectos relacionados ao desenvolvimento do vegetal (Lelièvre et al., 1997).

Segundo Yang (1985), o que leva ao amadurecimento é a diminuição da resistência à ação do etileno, portanto, o aumento da produção de etileno pelo sistema I não seria pré-requisito para iniciar o amadurecimento. Desta forma, o autor classifica os frutos climatéricos em: frutos do tipo I e frutos do tipo II. Nos frutos do tipo I como banana e tomate, a produção de etileno aumenta antes do começo do amadurecimento. No caso dos frutos do tipo II, o começo do amadurecimento não é precedido pelo aumento da produção de etileno, como em maçã, abacate e cherimoia.

O amadurecimento de frutos não-climátericos sempre foi entendido como um processo independente da ação do etileno, já que estes frutos apresentam baixos níveis de produção durante o amadurecimento. Entretanto, vários autores (Goldschmidt et al., 1993; Ferrarese et al., 1995; Harpster et al., 1997) têm demonstrado que o etileno regula alguns aspectos do amadurecimento em frutos não-climatéricos.

A aplicação de etileno exógeno em frutos não-climatéricos promove aumento da respiração, mas, ao contrário dos frutos climatéricos, o aumento da respiração cessa após a remoção do etileno (Biale, 1964). Porém, as diferentes respostas obtidas pela aplicação de etileno exógeno em frutos não-climatéricos levaram Goldschmidt (1997) a classificar os frutos não-climatéricos em: frutos que respondem a aplicação de etileno e frutos que não respondem. Em pimenta, o etileno também estimula a biossíntese de carotenóides (Ferrarese et al., 1995). Em citros, a perda da coloração é reduzida quando o etileno é bloqueado (Goldschmidt et al., 1993). Entretanto a aplicação de etileno em morango não promove qualquer resposta (Manning, 1993).

Para Abdi et al (1998), a classificação dos frutos em climatéricos e nãoclimatéricos é uma grande simplificação do processo de amadurecimento. Alguns cultivares de pêssego e pêras apresentam um pico reduzido de respiração diferentemente de frutos típicos climatéricos (Abdi et al., 1997; Downs et al., 1991). 


\subsubsection{Relação entre a respiração climatérica e o etileno}

O climatérico por definição é um período na ontegenia de determinadas frutas, durante o qual uma série de mudanças bioquímicas irreversíveis são geralmente iniciadas devido à produção autocatalítica de etileno, definindo a transição entre o crescimento e a senescência e resultando em um aumento na respiração (Rhodes, 1980).

A respiração climatérica dos frutos durante o amadurecimento foi entendida, inicialmente, como necessária na produção de energia para a síntese de novos compostos. Porém, Solomos $(1977)^{2}$, estimou que a energia gerada pela respiração basal é suficiente para os diversos eventos relacionados ao amadurecimento.

Cada célula do fruto é um sistema em equilíbrio dinâmico, onde a imposição de qualquer tipo de estresse ou estímulo gera como resposta compensatória um ajuste, seja ele estrutural ou metabólico. Assim, a respiração climatérica é um processo homeostático da célula devido aos efeitos degradativos da senescência. Dentro deste conceito, a biossíntese de etileno, operando em retroalimentação positiva, intensifica estes efeitos. A fase pós-climatérica representa a perda da capacidade homeostática da célula resultando na predominância dos processos senescentes (Romani, 1984).

A teoria que a respiração climatérica é uma resposta aos efeitos da ação etileno torna-se clara nos frutos não-climatéricos. Nestes frutos, que de modo geral apresentam baixa produção de etileno e diminuição nas taxas respiratórias durante o amadurecimento, a taxa respiratória aumenta quando se aplica etileno exógeno. A magnitude deste aumento é diretamente proporcional à concentração de etileno aplicado (Mattoo \& Sutle, 1991).

Dada a importância do climatério no amadurecimento dos frutos é importante que os eventos associados a esta fase sejam entendidos e caracterizados nas diferentes espécies e variedades de frutos.

\footnotetext{
2 (Citado por Romani, R.J. Canadian journal of Botany. v.62, n.12,2950-2955, 1984).
} 


\subsection{A cultura da goiaba}

\subsubsection{Aspectos gerais}

A goiabeira (Psidium guajava L), pertence à família Myrtacea, tendo como centro de origem as regiões tropicais da América (Pereira, 1995). No Brasil, a produção de goiabas é de aproximadamente 240 mil toneladas (FNP, 2002), sendo que $60 \%$ desta produção concentra-se no estado de São Paulo. Segundo Kavati (1997), a cultivar mais difundida, atualmente, para a produção de fruta fresca no estado de São Paulo é a 'Pedro Sato'. Selecionada por agricultores do Estado do Rio de Janeiro (Pereira, 1995) esta variedade se destaca por possuir frutos grandes e película rugosa. O formato é oblongo, a polpa é rosada, espessa e firme, possuindo cavidade cheia e com poucas sementes.

A goiaba é uma baga globosa, apresentando mesocarpo de textura firme e quatro a cinco lóculos preenchidos por uma massa de consistência pastosa com numerosas sementes (Pereira, 1995).

Segundo Mercado-Silva et al. (1998) e Akamine \& Goo (1979), o fruto apresenta crescimento semelhante a distribuição da curva do tipo sigmoidal dupla, com três fases distintas. Na primeira fase ocorre o rápido incremento do peso com o desenvolvimento do diâmetro. A segunda é caracterizada por pequenas mudanças no diâmetro e na terceira fase $\mathrm{o}$ fruto atinge $\mathrm{o}$ tamanho final.

A goiaba se destaca, dentre os frutos tropicais, devido às suas boas características organolépticas (sabor e aroma) e nutricionais, sendo fonte de vitamina C, açúcares, fibras e minerais (El Bulk, 1997). Em função das descobertas recentes da ação do licopeno no controle de células cancerígenas, a goiaba tem despertado interesse, pois apresenta teores considerados elevados, entre 4 a $7 \mathrm{mg} \cdot 100 \mathrm{~g}^{-1}$ de polpa (Adulse \& Kadam,1995).

O conteúdo de vitamina $\mathrm{C}$ na maioria das variedades brasileiras encontra-se em

torno de 100mg.100g ${ }^{-1}$ de polpa (Manica et al, 2000). Entretanto, o conteúdo de vitamina $\mathrm{C}$, bem como os demais componentes físicos e químicos dos frutos são influenciados pelas condições edafoclimáticas, tratos culturais, aspectos nutricionais, cultivares e estádio de maturação (Gerhardt et al., 1997). 
A goiaba, em função de sua elevada taxa metabólica apresenta uma "vida de prateleira" restrita a um máximo de 8 dias (Mowlah \& Itoo, 1983). Este fator, somado a manejos inadequados na pós-colheita resulta em perda da qualidade e dificuldades na comercialização em mercados distantes dos locais de produção.

\subsubsection{Padrão respiratório}

Os dados em relação ao comportamento respiratório de goiabas são contraditórios. Para Botelho (1996), esta seria uma característica varietal, podendo ocorrer cultivares climatéricas e não-climatéricas. De acordo com Biale e Barcus (1970), a goiaba é um fruto não-climatérico.Esses autores estudaram variedades da região 35 a $46 \mathrm{ml} . \mathrm{kg}^{-1} \mathrm{~h}^{-1}$. Medina (1978) e Chitarra \& Chitarra (1990) também consideraram a goiaba como um fruto não-climatérico.

Entretanto, Akamine \& Goo (1979) analisaram a respiração de duas cultivares de Psidium guajava e duas de Psidium cattleianum, no estádio de plena maturação e verificaram que todas apresentaram respiração climatérica e pico de produção de etileno bem definidos.

O comportamento de 6 cultivares de Psidium guajava colhidas em quatro diferentes estádios de maturação, desde frutos imaturos a totalmente desenvolvidos, foi estudado por Brown \& Wills (1983). Todas as cultivares examinadas mostraram atividade respiratória e produção de etileno do tipo climatérica. Os frutos mais maduros alcançaram o pico climatérico 4 a 6 dias após a colheita, enquanto os frutos imaturos apresentaram menor produção de etileno e de $\mathrm{CO}_{2}$ e não completaram seu desenvolvimento.

Oliveira (1996), também observou comportamento do tipo climatérico para goiaba branca 'Kumagai', a qual apresentou pico de respiração de 51,38 ml CO $\mathrm{kg}^{-1} \cdot \mathrm{h}^{-1}$ nove dias após a colheita para frutos armazenados a $21-29^{\circ} \mathrm{C}$ e $65-83 \% \mathrm{UR}$.

Mercado-Silva et al. (1998), trabalhando com goiabas Mexicanas, colhidas em três estádios de maturação e em duas épocas do ano, verificaram aumentos acentuados da atividade respiratória durante a pós-colheita. Os frutos colhidos na primavera-verão e 
em estádio maduro (ângulo de cor ${ }^{\circ} \mathrm{h}=95,2$ ) apresentaram pico de respiração quatro dias após a colheita, enquanto que os frutos colhidos nos estádio verde $\left({ }^{\circ} \mathrm{h}=116,3\right)$ e meiomaduro $\left({ }^{\circ} \mathrm{h}=107,4\right)$ o pico ocorreu cinco dia após a colheita. Em relação à produção de etileno estes autores doservaram um pico de produção que antecedeu em um dia o pico da respiração.

Para a cultivar Pedro Sato, Mattiuz (2002), estudando a influência de injúrias mecânicas no processo respiratório e nos parâmetros de goiabas, não verificou pico respiratório até o sétimo dia de armazenamento, quando os frutos já se encontravam em fase adiantada de senescência.

\subsubsection{Estádios de maturação, ponto de colheita e qualidade do fruto.}

O estádio de maturação, no qual os frutos são colhidos, determina a qualidade do fruto a ser oferecido ao consumidor. Os frutos colhidos imaturos, além da qualidade pobre, têm alto índice de perda de água e são muito suscetíveis às desordens fisiológicas. Por outro lado, quando colhidos muito maduros, entram rapidamente em senescência (Bleinroth, 1996). Para goiaba, não existe uma padronização e um consenso do estádio de maturação ideal para a colheita. As goiabas normalmente são colhidas quando a polpa ainda está firme e a coloração da casca começa mudar de verde-escuro para verde-claro ou começando amarelecer (Manica et al., 2000).

A correta determinação do estádio de maturação em que um fruto se encontra é essencial para que a colheita seja efetuada no momento certo. Para isso, são utilizados os chamados índices de maturação. Esses índices compreendem medidas físicas ou químicas que sofrem mudanças perceptíveis ao longo da maturação da fruta. $\mathrm{O}$ s índices de maturação devem assegurar a obtenção de frutas de boa qualidade, no que se refere às características sensoriais, além de um comportamento adequado, durante o armazenamento (Kluge et al., 2002).

Segundo Pantástico (1975), a determinação da maturidade pode ser feita por vários métodos: observações visuais (cor da casca, tamanho e formato do fruto), análises químicas (porcentagem de acidez e de sólidos solúveis totais, teor de amido), 
fenológicos (dias após a antese), fisiológicos (respiração e síntese de etileno) e físicos (abscisão, densidade e firmeza).

A determinação do estádio de maturação com base em apenas um dos métodos descritos anteriormente é normalmente falha. É necessário que o maior número de métodos possíveis sejam utilizados de modo integrado, visto que, o processo de maturação envolve inúmeras mudanças e estas estão sujeitas tanto a variações ambientas quanto varietais. Além disso, os índices utilizados para a determinação do estádio de maturação devem ser práticos, para que os produtores possam utilizá-los de maneira eficiente.

\subsubsection{1 Índices de maturação}

\section{- Cor}

Durante o amadurecimento, a maioria dos frutos apresenta modificações de cor. Desta forma a cor torna-se um atributo importante na determinação do estádio de maturação e qualidade comestível do fruto. As mudanças de coloração são resultantes não só da degradação da clorofila, como também, da síntese de pigmentos, principalmente carotenóides e antocianainas (Tucker, 1993).

A degradação da clorofila é o processo predominante na mudança de cor dos frutos. A degradação da clorofila ocorre em função das mudanças de $\mathrm{pH}$, de ácidos, do aumento dos processos oxidativos e da ação das clorofilases (Wills et al., 1998).

Em goiabas brancas 'Kumagai', sob diferentes doses de irradiação, Frateschi (1999), verificou diminuição da quantidade de clorofila em todos os tratamentos.

A determinação da coloração dos frutos pode ser feita por métodos subjetivos, os quais baseiam-se na intensidade e nas variações da cor perceptíveis ao olho humano. A determinação também pode ser feita por equipamentos capazes de medir a quantidade e qualidade da luz refletida do produto, sendo estes, método objetivos que garantem maior confiabilidade na utilização deste parâmetro (Chitarra \& Chitarra 1990). 
A goiaba sofre modificações de coloração, durante o amadurecimento, principalmente na cor da casca. Nas goiabas de polpa vermelha a cor da casca muda de verde escura para amarela durante o amadurecimento, enquanto que a cor da polpa muda de rosa para vermelho (Pereira \& Martinez Jr., 1986).

Segundo Mercado-Silva et al. (1998), a cor da casca é o melhor índice para indicar o estádio de maturação para goiaba. Trabalhando com a variedade 'Media China' em diferentes épocas de desenvolvimento, os autores verificaram uma diminuição constante no ângulo de cor $(\mathrm{h})$ durante o amadurecimento. Os mesmos, concluíram que a colheita deve ser realizada quando os frutos apresentarem ${ }^{\circ} \mathrm{h}$ de $110 \pm 2$.

Para Bleinroth et al. (1992), deve-se ter cuidado em utilizar a cor como índice de maturação. Isto porque, frutos localizados em certas posições na copa, que recebem raios solares durante boa parte do dia e adquirem coloração muito intensa resultando em falsa indicação do estádio de maturação.

\section{- Firmeza}

Após a mudança da cor, o amolecimento do fruto é a transformação mais evidente que ocorre durante a maturação e amadurecimento. Além da importância do ponto de vista econômico, já que afeta a qualidade do fruto, a firmeza tem efeito na resistência ao transporte, na conservação e no ataque a microrganismos (Awad, 1993).

A diminuição da firmeza da polpa durante o amadurecimento é função, principalmente, da perda da integridade da parede celular. A degradação das moléculas polímeras constituintes da parede celular, como celulose, hemicelulose e pectina, gera alterações na parede celular levando ao amolecimento da polpa. Outros processos também podem levar ao amolecimento dos frutos, como a degradação do amido e a perda de turgor (Tucker, 1993).

A perda de turgor é um processo físico, decorrente da perda excessiva de água dos tecidos. Este é um processo importante após a colheita, em função da diferença da pressão de vapor existente entre os tecidos do fruto e a atmosfera do local de 
armazenamento. A perda de água, em torno de 5 a $10 \%$ da massa fresca, pode tornar o fruto impróprio para a comercialização (Kader, 1986).

A firmeza dos frutos é influenciada pelo estádio de maturação, condições climáticas durante o período de colheita e variabilidade genética (Paiva et al., 1995). A firmeza nos estádios iniciais de desenvolvimento da goiaba é devido à presença de substâncias pécticas as quais vão sendo degradas por ação enzimática proporcionando o amolecimento dos frutos (Huber, 1983).

A determinação da firmeza é uma forma prática de avaliar o estádio de maturação do fruto. Dhingra et al. (1983), consideraram verdes as goiabas com firmeza de 85 Newton $(\mathrm{N})$ e verde-amarelas aquelas com firmeza em torno de 51 a $66 \mathrm{~N}$.

\section{- Teor de sólidos solúveis totais (SST)}

Os sólidos solúveis totais representam os compostos solúveis em água presentes no fruto como açúcares, vitaminas, ácidos, aminoácidos e algumas pectinas. O teor de SST é dependente do estádio de maturação no qual o fruto é colhido e geralmente aumenta durante a maturação pela biossíntese ou degradação de polissacarídeos (Chitarra \& Chitarra, 1990).

Em goiaba, os açúcares totais representam de 50 a $90 \%$ do teor de sólidos solúveis (Rathore, 1976; Chitarra et al., 1981). Desta forma, o teor de SST pode ser utilizado como indicativo da quantidade de açúcares presentes no fruto.

Os principais açúcares presentes em goiaba, segundo Mowlah \& Itoo (1982), ElBulk et al. (1997), são frutose, glicose e sacarose, sendo a frutose a forma predominante. Estes autores verificaram que a frutose representa 55 a $59 \%$ dos açúcares redutores, e juntamente com a glicose somam 74 a $98 \%$ dos açúcares totais.

Em frutos maduros os teores de açúcares totais variam entre 4 e $9 \%$ (Pereira \&

Martinez Jr, 1986). Chitarra et al. (1981), trabalhando com as variedades IAC-4 e Guanabara, encontraram teores de açúcares variando entre: 2,5 a $5 \%$ (redutores); 0,2 1,3\% (não-redutores) e 3- $6 \%$ (açúcares totais). 
A glicose e a frutose são originadas da degradação da sacarose e dos polissacarídeos de reserva como o amido. A degradação das hexoses fosfatadas ocorre na respiração via glicólise ou no ciclo das pentoses fosfato (Nultsch, 2000).

Segundo Esteves \& Carvalho (1982), o aumento do grau de doçura durante a maturação está relacionado com a formação e o acréscimo contínuo de frutose.

Em relação aos teores de sólidos solúveis totais para goiaba foram encontrados na literatura valores entre 4,80 a 15,9\%, dependendo da variedade, estádio de maturação e condições climáticas (Gerhardt et al., 1997; Paiva, 1994; Chitarra, 1996).

Após a colheita o teor de sólidos solúveis totais em goiabas parece não sofrer alterações significativas (Jacomino, 1999; Xisto, 2002).

\section{- Acidez}

A acidez de um fruto é dada pela presença dos ácidos orgânicos. Os ácidos orgânicos servem de substrato para a respiração, sendo fundamentais na síntese de compostos Enólicos, lípidos e aromas voláteis. Os ácidos são encontrados nos vacúolos das células na forma livre e/ou combinados com sais, esteres e glicosídeos (Chitarra \& Chitarra, 1990).

O teor de ácidos orgânicos tende a diminuir durante o processo de maturação devido a oxidação dos ácidos no ciclo dos ácidos tricarboxílicos em decorrência da respiração (Brody, 1996). Assim, a variação da acidez pode ser um indicativo do estádio de maturação do fruto, já que a acidez decresce em função do avanço da maturação.

Em goiaba a acidez é devida, principalmente, à presença de ácidos cítrico e málico, sendo encontrados em menores quantidades, os ácidos galacturônico e fumárico (Chan, \& Kwok,1976).

A acidez é um dos critérios utilizados para a classificação da fruta pelo sabor. De acordo com Gehardt et al. (1997), a acidez total titulável da goiaba pode variar de 0,24 a 1,79mg de ácido cítrico100g polpa ${ }^{-1}$, o que permite classificá-la como sendo de sabor moderado e bem aceito pelo consumo de mesa. 
Mercado-Silva et al (1998), não verificaram diferenças significativas para acidez entre os estádios de maturação (verde, verde-amarelo e amarelo). Para a variedade estudada 'Media China' a acidez diminuiu após 7 dias de armazenamento, e o teor de acidez foi mais elevado nos frutos desenvolvidos durante o outono-inverno.

\section{- Relação sólidos solúveis totais e acidez total titulável (SST/ATT)}

A relação entre SST e ATT fornece um indicativo do sabor do fruto, pois relaciona a quantidade de açúcares e ácidos presentes. A relação SST/ATT tende a aumentar durante a maturação, devido ao aumento nos eores de açúcares e à diminuição dos ácidos. Desta forma, todos os fatores sejam eles ambientais ou fisiológicos, que interferem no metabolismo dos açúcares e ácidos, estarão interferindo na relação SST/ATT e consequentemente no sabor do fruto.

Segundo Chitarra \& Chitarra, 1990 deve-se ter cuidado em estabelecer esta relação, pois frutas insípidas, contendo baixos teores de ácidos e SST, apresentam relação elevada, o que pode conduzir a interpretações errôneas quanto à qualidade desta fruta.

A relação SST/ATT pode ser considerada um índice de maturação para goiabas, em que valores acima de 25 são indesejáveis pois as frutas apresentam sabor estranho (Chitarra et al., 1981). Segundo Reyes et al., (1976) a relação SST/ATT para goiabas verdes é de 7,3, enquanto que as verde-maduras e as maduras apresentam relações em torno de 7,8 e 16,5 , respectivamente.

Assim, como observado para o teor de sólidos solúveis totais, os valores encontrados na literatura para a relação SST/ATT são variáveis, ficando entre 3,85 e 36,24 (Gerhardt et al., 1997; Paiva, 1994). 


\section{- Ácido ascórbico (vitamina C)}

A biossíntese do ácido ascórbico nos vegetais é um processo não completamente entendido. Segundo Smirnoff et al. (2001), a biossíntese do ácido ascórbico em plantas tem como precursor a D-manose e L-galactose.

A principal forma ativa da vitamina $\mathrm{C}$ é o ácido ascórbico, mas o produto da sua oxidação, o ácido deidroascórbico, também é ativo (Pelletier \& Brassard, 1977). Segundo Mokady et al. (1984), as formas oxidadas e reduzidas da vitamina C possuem valores biológicos semelhantes, sendo necessária à determinação de ambos os ácidos para a correta determinação do conteúdo de vitamina $\mathrm{C}$.

No fruto inteiro de goiaba, toda a vitamina $\mathrm{C}$ está na forma de ácido ascórbico. Após a maceração ocorre rápida oxidação do ácido ascórbico e, aproximadamente após 3 horas, $60 \%$ do ácido ascórbico é convertido para ácido deidroascórbico sem perda no conteúdo de vitamina C (Mokady et al., 1984).

A goiaba apresenta teores elevados de ácido ascórbico, pode apresentar até 400 mg.100g polpa ${ }^{-1}$, com teores mais elevados na casca e na parte mais externa da polpa (Chitarra, 1996).

Danos mecânicos, apodrecimento e senescência promovem a desorganização da parede celular promovendo a oxidação do ácido áscórbico, provavelmente devido a presença das enzimas polifenol oxidase e ácido ascórbico oxidase (Mokady et al., 1984). Em goiabas 'Pedro Sato', Mattiuz (2002), observou redução no teor de ácido ascórbico em goiabas que sofreram injúrias mecânicas.

Lima \& Durigan (2000), avaliando a conservação de goiabas 'Pedro Sato' verificaram que a refrigeração proporcionou a manutenção de $87,0 \%$ do conteúdo inicial de ácido ascórbico que era de $123,0 \mathrm{mg}$ de ácido ascórbico100g de polpa ${ }^{-1}$. Em condições ambientes verificaram um decréscimo de até $64 \%$ do teor inicial.

De acordo com Dhillion et al. (1987) e Vazquez-Ochoa \& Colinas-Leon (1990), o conteúdo de ácido ascórbico aumenta no fruto durante os estádios iniciais de desenvolvimento até a maturação total e, quando excessivamente maduro, o conteúdo diminui significativamente. 


\section{ÍNDICES DE MATURAÇÃO E INFLUENCIA DO ESTÁDIO DE MATURAÇÃO NA QUALIDADE PÓS-COLHEITA DE GOIABAS 'PEDRO SATO'}

\section{RESUMO:}

O estádio de maturação, no qual os frutos são colhidos, determina a qualidade do fruto a ser oferecido ao consumidor. O presente trabalho teve como objetivos determinar os índices de maturação e avaliar a influência de três estádios de maturação nas transformações físico-químicas e na qualidade sensorial após a colheita de goiabas 'Pedro Sato'. Os frutos foram colhidos em três estádios de maturação segundo a cor da casca: Estádio 1 (cor da casca verde-escura; Estádio 2 (cor da casca verde-clara); Estádio 3 (cor da casca verde-amarela). Os frutos foram armazenados em câmara com temperatura controlada de $25 \pm 1{ }^{\circ} \mathrm{C}$ e $80 \pm 5 \%$ UR e avaliados quanto as transformações físico-químicas (perda de matéria fresca, cor da casca e da polpa, sólidos solúveis totais, acidez total titulável, firmeza da polpa e teor de ácido ascórbico) e porcentagem de podridão. A análise sensorial foi realizada no final do período de comercialização de cada estádio. No momento da colheita a cor da casca, a firmeza da polpa e a relação: sólidos solúveis totais (SST)/ acidez total titulável (ATT) apresentaram diferenças significativas entre os três estádios de maturação. Durante o amadurecimento, as transformações físico-químicas foram semelhantes entre os estádios de maturação. Sensorialmente os frutos colhidos no estádio 3 apresentaram as melhores notas para todos os atributos avaliados, seguido dos frutos colhidos nos estádio 2 e 1 . A cor da casca, a firmeza da polpa e a relação: SST/ATT podem ser considerados bons índices de maturação para goiaba 'Pedro Sato'.

Palavras chaves: Psidium guajava, pós-colheita, amadurecimento, qualidade sensorial. 


\section{MATURATION INDEXES AND THE INFLUENCE OF MATURATION STAGE IN THE POSTHARVEST QUALITY OF GUAVAS 'PEDRO SATO'}

\section{SUMMARY:}

The maturation stage, in which the fruit is picked, determines the quality of the fruit to be offered to the consumer. The present work had as objectives to determine the maturation indexes as well as evaluate the influence of three maturation stage in the physicochemical transformations and in the sensorial quality after the harvesting guavas 'Pedro Sato'. The guavas were picked in three maturation stage according to the color of the peel: Stage 1 (dark green peel); Stage 2 (light green peel); Stage 3 (yellowish green). The fruit lot was in a chamber with controlled temperature of $25 \pm 1{ }^{\circ} \mathrm{C}$ and $80 \pm 5 \% \mathrm{RH}$ and assessed for physicochemical transformations (loss of fresh matter, color of peel and pulp, total soluble solids, tirable acidity, firmness of the pulp, and grade of ascorbic acid) and rottenness percentage. The sensorial analysis was accomplished in the end of the commercialization period of each stage. In the moment of the crop the color of the peel, the firmness of the pulp and the ratio of total soluble solids (TSS) / titrable acidity (AT) showed significant differences among the three maturation stages. During the ripening, the physicochemical transformations were similar among the maturation stages. Sensorialy the guavas picked in the stage 3 presented the best grades for all assessed attributes, followed by the guavas picked in the stage 2 and 1 . The color of the peel, the firmness of the pulp and the TSS/AT ratio can be considered good maturation indexes for guava 'Pedro Sato'.

Key words: Psidium guajava, postharvest, ripening, sensorial quality. 


\subsection{INTRODUÇÃO}

O Brasil está entre os três maiores produtores mundiais de goiaba (Psidium guajava). A maior parte da produção é absorvida pela indústria, porém, no estado de São Paulo, principal produtor nacional, houve um incremento de $17 \%$ na produção de goiabas para mesa no período de 2000-2001 (www.iea, 2002).

A expansão do mercado consumidor de goiaba in natura está condicionada a qualidade dos frutos e ao aumento da vida útil pós-colheita. A goiaba é um fruto altamente perecível devido a seu intenso metabolismo durante o amadurecimento. Os atributos de qualidade são influenciados pelos cultivares, condições edafoclimáticas e práticas culturais. Manejos inadequados na colheita e na pós-colheita aceleraram os processos de senescência afetando sensivelmente a qualidade e limitando ainda mais o período de comercialização.

O estádio de maturação, no qual os frutos são colhidos, determina a qualidade do fruto a ser oferecido ao consumidor. Os frutos colhidos imaturos, além da qualidade pobre, têm alto índice de perda de água e são muito suscetíveis as desordens fisiológicas. Por outro lado, quando colhidos muito maduros entram rapidamente em senescência. Para goiaba, não existe uma padronização e um consenso do estádio de maturação ideal para a colheita e quais são os índices de maturação adequados.

As goiabas normalmente são colhidas quando a polpa ainda está firme e a coloração da casca começa mudar de verde-escuro para verde-claro ou começando amarelecer (Manica et al., 2000). De maneira geral quando as goiabas são destinadas a mercados distantes das áreas de produção, os frutos são colhidos em estádios inicias de maturação (cor da casca verde-escura), porém não existem estudos avaliando a qualidade destes frutos no momento do consumo.

Desta forma, o objetivo deste trabalho foi determinar as variáveis físico-químicas que podem ser usadas como indicadoras do estádio de maturação e determinar a influência de três estádios de maturação na qualidade pós-colheita de goiabas 'Pedro Sato'. 


\subsection{MATERIAL E MÉTODOS}

\section{- Local do Experimento e Colheita dos frutos}

O experimento foi conduzido no laboratório de Pós-colheita do Departamento de Produção Vegetal da Escola Superior de Agricultura "Luiz de Queiroz", ESALQ-USP no município de Piracicaba, SP.

Foram utilizadas goiabas da variedade Pedro Sato, provenientes de pomar comercial localizado no município de Vista Alegre, SP (48 $21^{\prime} 1 \mathrm{~W}$, e $\left.21^{\circ} 10^{\prime} \mathrm{S}\right)$. Os frutos foram colhidos em plantas conduzidas em sistema de poda contínua, sob irrigação, no mês de fevereiro de 2002.

Os frutos foram colhidos no início da manhã e transportados para a casa de embalagem da fazenda, onde foram selecionados frutos visualmente isentos de doenças e/ou danos mecânicos, em três diferentes estádios de maturação, segundo a cor da casca. Os mesmos foram envoltos individualmente em redes de polietileno para maior proteção, acondicionados em caixas de papelão e transportados para Piracicaba-SP.

\section{- Seleção e armazenamento}

No laboratório, os frutos foram novamente selecionados de forma a obter-se lotes uniformes. A cor da casca foi medida com colorimetro Minolta e os frutos foram separados nos estádios de maturação segundo o seguinte critério: Estádio 1: cor da casca verde-escura, ângulo de cor $\left({ }^{\circ} \mathrm{h}\right)$ entre 120 e 117; Estádio 2: cor da casca verde-clara, ângulo de cor $\left({ }^{\circ}\right.$ h) entre 116 e 113; Estádio 3: cor da casca verde-amarela, ângulo de cor $\left({ }^{\circ} \mathrm{h}\right)$ entre 112 e 108 (Figura 1)

Os frutos foram armazenados em câmara com controle de temperatura e umidade a de $25 \pm 1{ }^{\circ} \mathrm{C}$ e $85 \pm 5 \%$ UR 

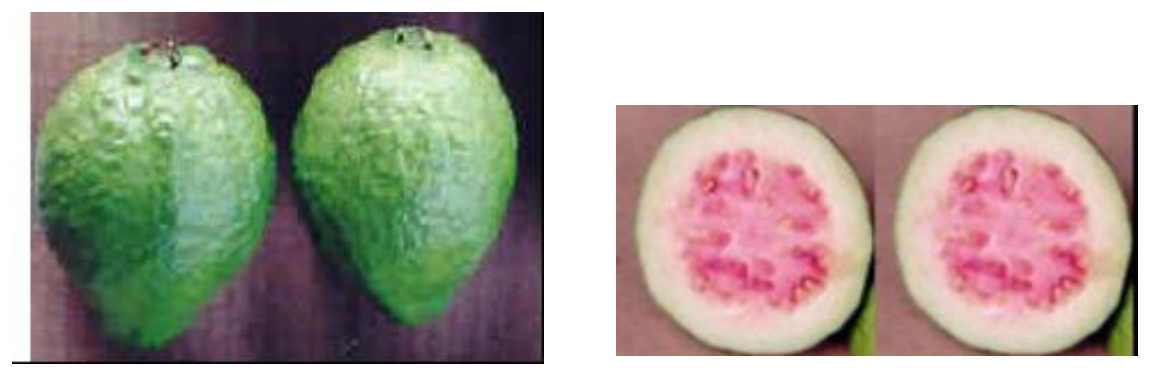

Estádio 1
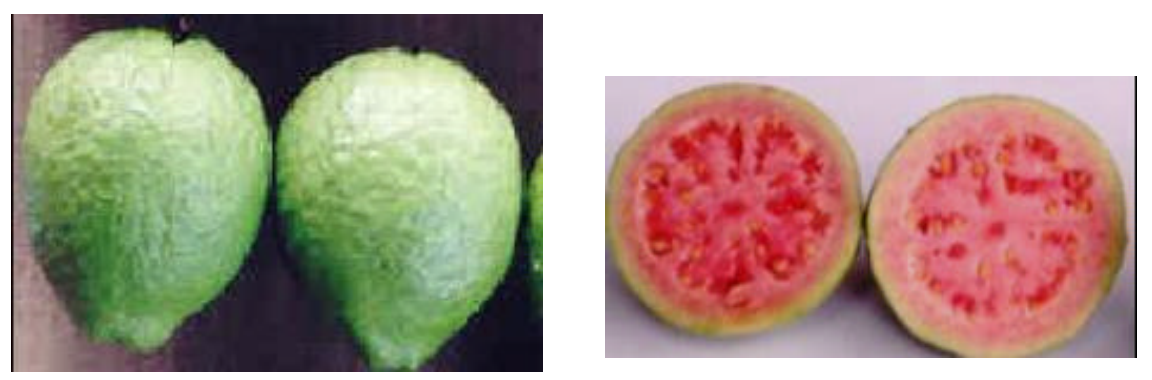

Estádio 2
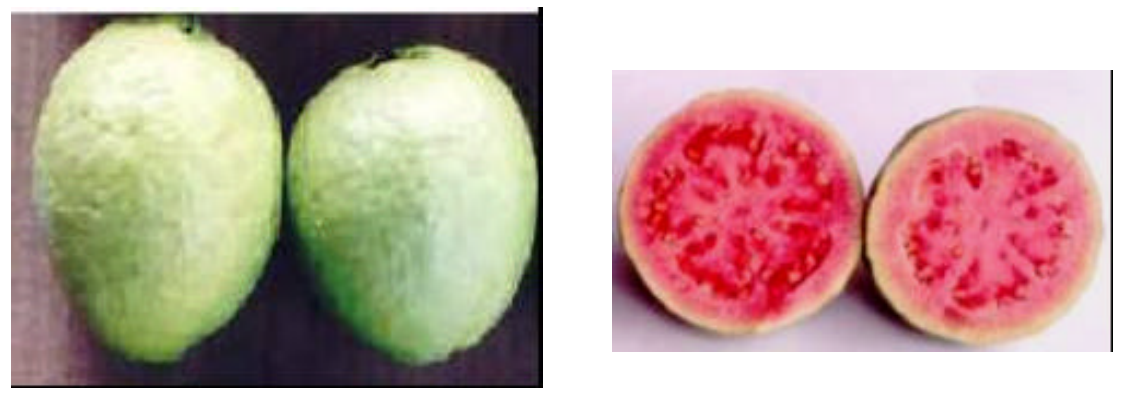

\section{Estádio 3}

Figura 1 - Três estádios de maturação de goiabas 'Pedro Sato', classificados segundo a cor da casca. Estádio 1: cor da casca verde-escura, ângulo de cor ( $\left.{ }^{\mathrm{h}} \mathrm{h}\right)$ entre 120 e 117; Estádio 2: cor da casca verde-clara, ângulo de cor $\left({ }^{\circ} \mathrm{h}\right)$ entre $116 \mathrm{e}$ 113; Estádio 3: cor da casca verde- amarela ângulo de cor $(\mathrm{h})$ entre $112 \mathrm{e}$ 108.

\section{- Análises físico-químicas}

As análises físico-químicas foram realizadas no momento da colheita e a cada dois dias até oito, seis e quatro dias após a colheita para os estádios 1, 2 e 3, respectivamente. Entretanto, com base na aparência, foi determinado o período comercializável, o qual foi utilizado para interpretação das análises, uma vez que a aparência é a principal causa de rejeição para goiaba (Yamashita \& Benassi, 
1998). Foram considerados inviáveis à comercialização lotes com mais de $30 \%$ de frutos com podridão, aspecto de murchamento e sobremaduros.

As análises físico-químicas efetuadas foram:

a) Cor da casca: determinada com o colorímetro Minolta, modelo CR-300, efetuandose 2 leituras por fruto, em lados opostos da sua região equatorial. Os resultados foram expressos em ângulo de cor $\left({ }^{\circ} h\right)$.

b) Cor da polpa: determinada com o colorímetro Minolta, efetuando-se 1 leitura no centro da polpa de cada fruto, os quais foram primeiramente cortados transversalmente. Os resultados foram expressos em cromaticidade (C).

c) Firmeza da polpa: determinada com penetrômetro digital, ponteira plana com $8 \mathrm{~mm}$ de diâmetro, tomando-se duas leituras por fruto em lados opostos de sua região equatorial. Antes de se efetuar a medida, retirou-se a casca no local da leitura, com auxílio de uma lâmina metálica. Os resultados foram expressos em Newton (N).

d) Sólidos solúveis totais (SST): os frutos foram triturados e separados das sementes obtendo-se uma polpa homogênea. Uma porção desta foi utilizada para a leitura direta em refratômetro digital. Os resultados foram expressos em ${ }^{\circ}$ Brix..

e) Acidez total titulável (ATT): determinada de acordo com metodologia descrita por Carvalho et al. (1990), onde $10 \mathrm{~g}$ de polpa foram homogeneizadas em $90 \mathrm{ml}$ de água destilada. A solução foi titulada com $\mathrm{NaOH} 0,1 \mathrm{~N}$ até pH 8,10. Os resultados foram expressos em \% de ácido cítrico.

f) Relação SST/ATT: Relação obtida, por meio da razão entre os valores de sólidos solúveis totais e acidez total titulável. 
g) Teor de Vitamina C: determinado de acordo com metodologia descrita por Carvalho et al. (1990), onde $10 \mathrm{~g}$ de polpa foram homogeneizada em $50 \mathrm{ml}$ de ácido oxálico (1 $\%$ ), em seguida a solução foi filtrada em papel de filtro. Após a filtragem as amostras foram tituladas com DCFI (2.6 diclorofenol indofenol de sódio). Os resultados expressos em mg ácido ascórbico $100 \mathrm{~g} \mathrm{polpa}^{-1}$.

h) Porcentagem de podridão: determinado pela contagem de goiabas com presença de podridão. Foi considerado podre, o fruto com lesões $\geq 0,3 \mathrm{~cm}$. Os resultados foram expressos em porcentagem de goiabas com podridão.

i) Perda de massa fresca: determinada pela diferença entre a massa do fruto no momento da colheita e a massa deste após o período de armazenamento. Os resultados foram expressos em porcentagem de perda de massa fresca.

\section{- Análise sensorial}

Os frutos foram analisados sensorialmente ao final do período comercializável. Este período foi determinado pelas análises físico-químicas. Desta forma, após dois dias da colheita foram analisados os frutos colhidos no estádio 3 de maturação. Os frutos colhidos no estádio 2 de maturação foram analisados quatro dias após a colheita e os frutos colhidos no estádio 1 foram analisados seis dias após a colheita.

Os frutos foram lavados em água corrente, cortados em oito fatias longitudinais e colocados em pequenas bandejas de polietileno teneftalato, as quais foram fechadas com tampa própria (Figura 2). Logo após o preparo, foram colocadas duas fatias em cada bandeja e oferecidas aos provadores que avaliaram a amostra quanto ao odor, sabor, textura, aparência externa e qualidade global, segundo a seguinte escala de notas desenvolvida por Peryam et al. (1952): 1 = Péssimo; 2 = Muito Ruim; 3 = Ruim; 4 =

Regular; 5 = Bom; 6 = Muito Bom e 7 = Ótimo. $O$ modelo da ficha utilizada para avaliação das amostras em anexo (Apêndice 1). 
Para a avaliação da aparência externa, os provadores receberam uma amostra contendo 3 frutos inteiros acondicionados em uma bandeja de poliestireno expandido (Figura 3). A ficha de avaliação contou também com espaço para comentários sobre as o às características do fruto mais apreciadas e menos apreciadas pelo provador (ApêndiceFigura 1). A análise foi realizada com 40 provadores não treinados, os quais foram mantidos nas 3 avaliações.

\section{- Delineamento estatístico}

O delineamento estatístico empregado na análise físico-química foi inteiramente casualizado. Utilizaram-se 5 repetições de 3 frutos para cada tratamento e período de análise. Para análise sensorial o delineamento foi blocos ao acaso, sendo cada provador considerado um bloco.

Os dados foram submetidos à análise de variação pelo teste $\mathrm{F}$, utilizando-se $\mathrm{o}$ Sistema de Análise Estatística (SANEST). As médias foram comparadas pelo Teste de Tukey a $5 \%$ de probabilidade. Os resultados das análises também foram submetidos à análise do desvio padrão. As diferenças entre dois tratamentos maior que a soma de dois desvios padrões foram consideradas significativas.

Com o objetivo de estabelecer as correlações existentes entre as variáveis físicoquímicas nos diferentes estádios de maturação foram calculados os coeficientes de correlação entre as variáveis estudadas. Os coeficientes foram obtidos a partir da seguinte fórmula:

$$
R=\frac{\sum\left(x_{i}-\bar{x}\right)\left(y_{i}-\bar{y}\right)}{\left[\sum\left(x_{i}-\bar{x}\right)^{2} \sum\left(y_{i}-\bar{y}\right)^{2}\right]^{1 / 2}}=\frac{\left(\sum x_{i} y_{i}\right)-\left(\sum x_{i}\right)\left(\sum y_{i}\right) / n}{\left\{\cdot\left[\left(\sum x_{i}{ }^{2}\right)-\left(\sum x_{i}\right)^{2} / n\right] \cdot\left[\left(\sum y_{i}{ }^{2}\right)-\left(\sum y_{i}\right)^{2} / n\right] .\right\}^{1 / 2}}=\hat{a} \frac{S_{x}}{S_{y}}
$$

$\mathrm{X}, \mathrm{Y} \rightarrow$ variáveis aleatórias

$S_{x}, S_{y} \rightarrow$ desvios padrão estimados (em relação às médias) 


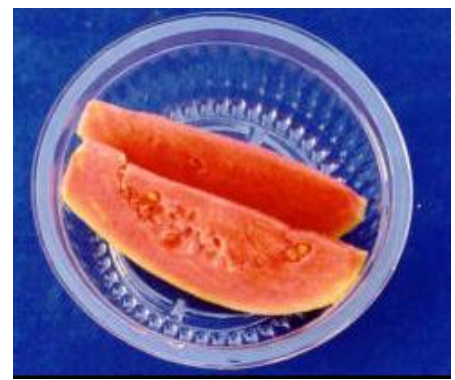

Figura 2 - Porção de goiaba acondicionada em embalagen para análise sensorial.

Estádio 1

(6 dias após a colheita)

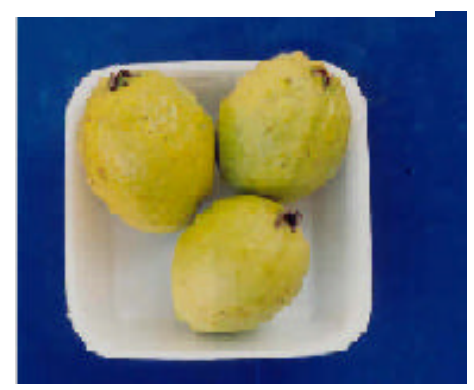

Estádio 2

(4 dias após a colheita)

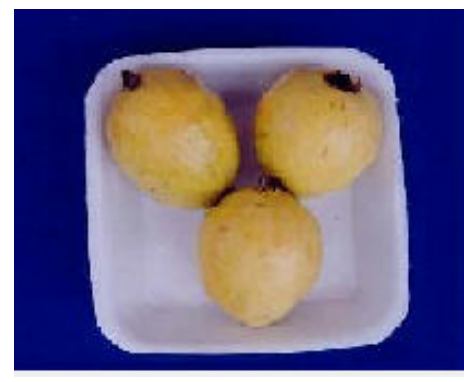

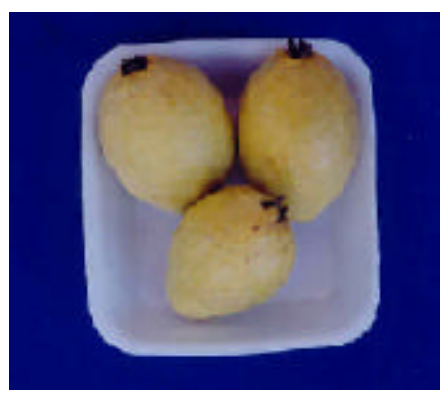

Estádio 3

(2 dias após a colheita)

Figura 3- Frutos para avaliação da aparência externa na análise sensorial. Cor da casca no momento da colheita: Estádio 1- cor da casca verde-escura, ângulo de cor $\left({ }^{\circ} \mathrm{h}\right)$ entre 120 e 117; Estádio 2 cor da casca verde-clara, ângulo de cor $\left({ }^{\circ} \mathrm{h}\right)$ entre 116 e 113; Estádio 3- cor da casca verde-amarela, ângulo de cor ( $\left.{ }^{\mathrm{h}} \mathrm{h}\right)$ entre 112 e 108 . 


\subsection{RESULTADOS E DISCUSSÃO}

\subsubsection{Caracterização dos estádios de maturação}

Os estádios de maturação devem ser caracterizados por um conjunto de variáveis capazes de expressar a fase de desenvolvimento do fruto e conseqüentemente sua qualidade sensorial. A Tabela 1 apresenta as características físico-químicas de goiabas 'Pedro Sato', colhidas em três estádios de maturação.

A utilização da cor da casca para a distinção dos estádios de maturação mostrou ser viável, considerando as outras diferenças significativas apresentadas entre as demais variáveis analisadas. Esta variável apresenta baixo coeficiente de variação oferecendo maior confiabilidade da medida. O ângulo de cor $(\mathrm{h})$ expressa de modo significativo as diferenças na coloração da casca, permitindo uma visualização precisa da mudança de cor (Tabela 1). Estes resultados estão de acordo com Mercado-Silva et al. (1998), que elegeram a cor como o melhor índice para a determinação do ponto de maturação para goiaba 'Media China'.

A firmeza da polpa separou de modo significativo os três estádios de maturação. A firmeza do estádio 2 foi 23, $1 \%$ menor que a do estádio 1 . Para os frutos colhidos no estádio 3 a firmeza foi 40,3 \% menor que a firmeza dos frutos colhidos no estádio 2 e cerca da metade da firmeza dos frutos colhidos no estádio 1 (Tabela 1). Estes resultados estão próximos dos obtidos por Dingra et al. (1983), os quais consideraram verdes as goiabas com firmeza acima de $85 \mathrm{~N}$ e verde-amarelas goiabas com firmeza em torno de $55,11 \mathrm{~N}$ e $66,3 \mathrm{~N}$.

Em relação à cor da polpa, verificou-se pouca diferença entre o 3 estádios. Foi possível distinguir apenas o estádio 1 , dos demais estádios. 
Tabela 1. Características físico-químicas de goiabas 'Pedro Sato’ em três estádios de maturação, no momento da colheita.

\begin{tabular}{|c|c|c|c|c|}
\hline \multirow[b]{2}{*}{ Índices de maturação } & \multicolumn{4}{|c|}{ Estádios de maturação $^{1}$} \\
\hline & Estádio 1 & Estádio 2 & Estádio 3 & $\begin{array}{l}\text { C.V } \\
(\%)\end{array}$ \\
\hline Cor da casca $\left({ }^{\circ} \mathrm{h}\right)$ & 119,17 a & $115,03 \mathrm{~b}$ & $110,89 \mathrm{c}$ & 1,3 \\
\hline Firmeza $(\mathrm{N})$ & $100,80 \mathrm{a}$ & $77,60 \mathrm{~b}$ & $46,30 \mathrm{c}$ & 13,1 \\
\hline Cor da polpa (Croma) & $30,36 \mathrm{a}$ & $33,38 \mathrm{~b}$ & $34,57 \mathrm{~b}$ & 7,8 \\
\hline Sólidos solúveis totais $\left({ }^{0}\right.$ Brix $)$ & $6,9 \mathrm{a}$ & $7,3 \mathrm{ab}$ & $7,6 \mathrm{~b}$ & 9,3 \\
\hline Acidez Total Titulável (\% ácido cítrico) & $0,60 \mathrm{a}$ & $0,54 \mathrm{~b}$ & $0,51 \mathrm{~b}$ & 8,7 \\
\hline Relação SST/ATT & $11,6 \mathrm{a}$ & $13,6 \mathrm{~b}$ & $15,1 \mathrm{c}$ & 10,7 \\
\hline Vitamina C (mg ác. ascórbico. $100 \mathrm{~g}^{-1}$ polpa) & $30,35 \mathrm{a}$ & $44,47 \mathrm{ab}$ & $48,77 \mathrm{~b}$ & 21,7 \\
\hline
\end{tabular}

Médias seguidas pela mesma letra na linha não diferem entre si pelo teste de Tukey a 5\% de probabilidade.

${ }^{1}$ Estádios de maturação no momento da colheita em função da cor da casca: Estádio 1: cor da casca verde-escura; Estádio 2: frutos com cor da casca verde-clara; Estádio 3: frutos com cor da casca verde-amarela.

O teor de sólidos solúveis totais (SST) diferenciou apenas o estádio 3 do estádio 1, o qual apresentou $0,7{ }^{\circ}$ Brix a mais que o primeiro. $\mathrm{O}$ estádio 2 apresentou valores intermediários.

Em goiaba, os açúcares totais representam cerca de 51 a $91 \%$ do teor de sólidos solúveis (Rathore, 1976; Chitarra et al., 1981), sendo que o principal açúcar é a frutose. Assim, entende-se que o teor de SST está sob influência de fatores que afetam a síntese de frutose. A goiaba, diferentemente de outros frutos como, maçã e banana, possui baixo teor de amido. Este componente, quando em alta concentração no fruto, contribui de forma significativa para o aumento do teor de SST durante o amadurecimento. Em goiabas o amido representa 1 a $3 \%$ do total dos carboidratos não estruturais (Lazan \& Ali, 1998), não contribuindo de forma significativa para o aumento do teor de açúcares solúveis, durante o amadurecimento. 
O teor de SST está sujeito a inúmeras variações, assim o estabelecimento de um intervalo do teor de SST que represente um estádio de maturação torna-se difícil. Desta forma, semelhante a Mercado-Silva et al. (1998), verificou-se que para a goiaba, o teor de sólidos solúveis totais não representa um bom índice para caracterização dos estádios de maturação.

A acidez total titulável (ATT) apresentou diferenças significativas entre os estádios 1 e 2 e entre os estádios 1 e 3, porém, não separou estatisticamente os estádios 2 e 3 (Tabela1). Conforme esperado, o teor de ATT, foi maior no estádio $1(0,6 \%)$ e menor no estádio $3(0,51 \%)$. Estes resultados estão de acordo com os de Pivetta et al. (1992), que observaram, para a cultivar Paluma, valores maiores de acidez para os frutos colhidos nos estádio verde que os frutos colhidos no estádio de 'de vez' e maduros.

Diferentemente dos teores de SST e ATT, a relação entre estas variáveis (SST/ATT), foi um índice que diferenciou os três estádios de maturação (Tabela 1). Estes resultados estão de acordo com os obtidos por Tripathi \& Gangwar (1971) e Chitarra et al. (1981), os quais sugerem a utilização da relação SST/ ATT como índice de maturação para goiabas.

O teor de ácido ascórbico apresentou diferenças significativas somente entre os estádios 1 e 3. Observou-se teores maiores de ácido ascórbico nos frutos em estádios mais avançados de maturação. Estes resultados estão de acordo com os encontrados por El-Bulk et al. (1997), os quais observaram teores crescentes de ácido ascórbico durante a maturação para todas as cultivares estudadas (Shambati, Pakistani, Shendi e Ganib).

A utilização de mais de uma variável para a determinação do estádio de maturação possibilita caracterizar de forma mais precisa o estádio de desenvolvimento do fruto. Entretanto, conhecendo-se o grau de relação entre as variáveis é possível avaliar um variável em função da outra. Verificou-se que para a goiaba 'Pedro Sato', as melhores relações são entre a cor da casca, cor da polpa e firmeza da polpa. Isto pode ser verificado pelo alto coeficiente de correlação obtido entre estas variáveis (Tabela 2).

Os teores de SST, ATT e vitamina C apresentaram baixo coeficiente de correlação com todas as variáveis estudadas. Isto, foi devido as discretas mudanças que 
estas variáveis sofreram, durante o amadurecimento, ao contrário das intensas mudanças da cor casca e cor da polpa e firmeza da polpa.

Tabela 2. Coeficientes de correlação entre as variáveis físico-químicas de goiabas 'Pedro Sato' colhidas em três estádios de maturação ${ }^{1}$.

\begin{tabular}{lccccc}
\hline \multirow{2}{*}{ Variáveis } & $\begin{array}{c}\text { Cor polpa } \\
\left({ }^{0} \mathrm{~h}\right)\end{array}$ & $\begin{array}{c}\text { Firmeza } \\
(\mathrm{N})\end{array}$ & $\begin{array}{c}\text { SST } \\
\left({ }^{0} \text { Brix }\right)\end{array}$ & $\begin{array}{c}\text { ATT } \\
(\%)\end{array}$ & $\begin{array}{c}\text { Vitamina C } \\
(\mathrm{mg} \text { àc.ascórbico100g }\end{array}$ \\
\cline { 2 - 6 } Cor casca & $-0,75$ & 0,80 & 0,24 & 0,54 & -0.25 \\
Cor polpa & & -0.77 & 0,04 & $-0,31$ & 0,05 \\
Firmeza & & & 0,08 & 0,55 & $-0,08$ \\
SST & & & & $-0,05$ & 0,04 \\
ATT & & & & & 0,03 \\
\hline
\end{tabular}

${ }^{T}$ Estádio de maturação 1, 2 e 3 frutos colhidos com cor da casca verde-escura, verde clara e verde-amarela, respectivamente).

\subsubsection{Mudanças físico-químicas em goiabas 'Pedro-Sato' colhidas em três estádios de maturação.}

O estádio de maturação dos frutos indica diferentes etapas do desenvolvimento. Conseqüentemente, isto pode resultar em distinções nos processos metabólicos após a colheita, interferindo na qualidade do fruto.

Os frutos apresentaram períodos de conservação diferentes em função do estádio de maturação no momento. Na Figura 4, observa-se a porcentagem de frutos com podridão, sendo esta a principal causa da redução do período comercializável para todos os estádios de maturação. Os frutos colhidos no estádio 1, apresentaram período de comercialização de 6 dias, enquanto este período foi de 4 e 2 dias para os estádios 2 e 3 , respectivamente. As lesões foram provocadas devido à ação do fungo identificado como Colletotrichum gloeosporioides, que, segundo Bleinroth (1996), é o principal patógeno em pós-colheita de goiaba. 
A perda de massa fresca foi crescente durante o amadurecimento, chegando a valores máximos de 3,5\% em relação à massa inicial (Figura 4). Os estádios apresentam pouca influência sob esta variável.

A perda de massa fresca dos frutos é uma variável importante que está diretamente relacionada com a qualidade do fruto. Segundo Bem-Yehoshua (1985), um dos principais problemas durante o armazenamento de frutas e hortaliças é a perda de massa do fruto devido ao processo de transpiração. A perda de água leva ao amolecimento dos tecidos, tornando os frutos mais susceptíveis às deteriorações, bem como, a alterações na cor e sabor.
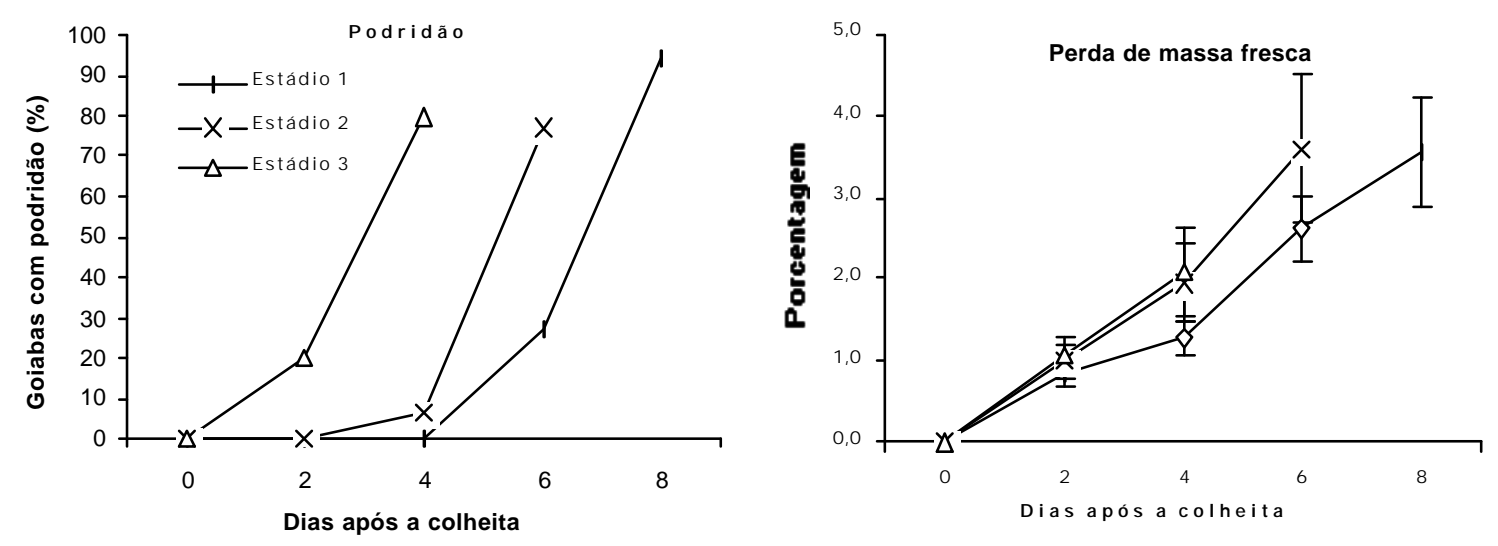

Figura 4- Influência dos estádios de maturação na porcentagem de podridão e na perda de massa fresca de goiabas 'Pedro Sato'.(Estádio de maturação 1, 2 e 3 frutos colhidos com cor da casca verde-escura, verde-clara e verde-amarela, respectivamente).

$\mathrm{Na}$ cor da casca verificou-se diminuição dos valores de ângulo ( $\mathrm{h}$ ) independente do estádio de maturação no momento da colheita, indicando a perda da coloração verde e o aparecimento da coloração amarela. A coloração totalmente amarela foi verificada quando os frutos atingiram ângulo de cor $<100$ (Figura 5). 
Para cor da polpa observou-se constante aumento da cromaticidade para todos os estádios, indicando a mudança de cor rosa para vermelho intenso. $\mathrm{O}$ aumento da intensidade de coloração é provavelmente devido a biossíntese de licopeno. A cor da polpa foi semelhante entre os estádios 2 e 3 e levemente mais intensa do que a do estádio 1 durante todo o período de armazenamento (Figura 5). Os três estádios apresentaram comportamento semelhante em relação à perda de firmeza (Figura 5). Os frutos sofreram rápida perda de firmeza independente do estádio de maturação confirmando os dados obtidos por Piveta et al. (1992). As maiores perdas da firmeza foram verificadas entre zero e dois dias para o estádio 3, quando a firmeza passou de 48,3 $\mathrm{N}$ para 24,9 $\mathrm{N}$, entre dois e quatro dias para o estádio 2, quando a firmeza passou de $58,21 \mathrm{~N}$ e $21,14 \mathrm{~N}$ e entre quatro e seis dias para o estádio 1, quando a firmeza passou de 77,92 $\mathrm{N}$ para 26,15 N.

De modo geral, o estádio 3 apresentou maior teor de sólidos solúveis (SST), seguido dos estádios 2 e 1 . O teor de SST apresentou poucas mudanças no decorrer do amadurecimento para todos os estádios de maturação. Estes resultados estão de acordo com os obtidos por Jacomino (1999), para goiabas 'Kumagai'. Em relação à acidez total titulável verificou-se de modo geral uma tendência crescente nos teores, com posterior decréscimo. A porcentagem de acidez foi crescente até quatro e dois dias após a colheita para os frutos colhidos nos estádios 1 e 2, respectivamente. Enquanto que para o estádio 3 a acidez foi decrescente a partir da colheita. Jacomino et al. (2001), também observaram um leve aumento no teor de ATT, durante o armazenamento de goiabas 'Kumagai' em diferentes embalagens e sob refrigeração. O mesmo comportamento foi verificado por Lima \& Durigan (2000), em goiabas 'Pedro Sato' armazenadas a $10^{\circ} \mathrm{C}$, em diferentes embalagens. Mattiuz (2002), avaliando o efeito de injurias mecânicas em goiabas 'Pedro Sato' e 'Paluma', colhidas em estádio “de vez”, também observou aumento dos teores de acidez até o quarto dia após a colheita. 

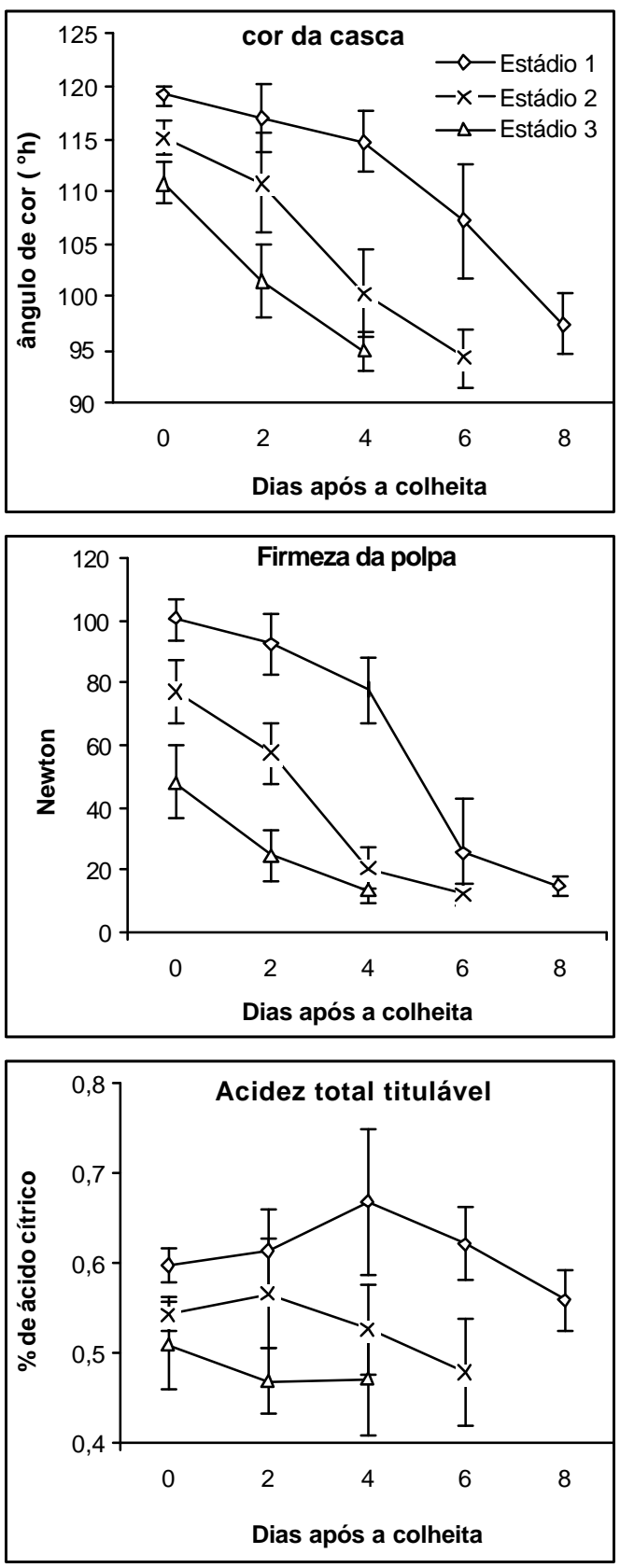
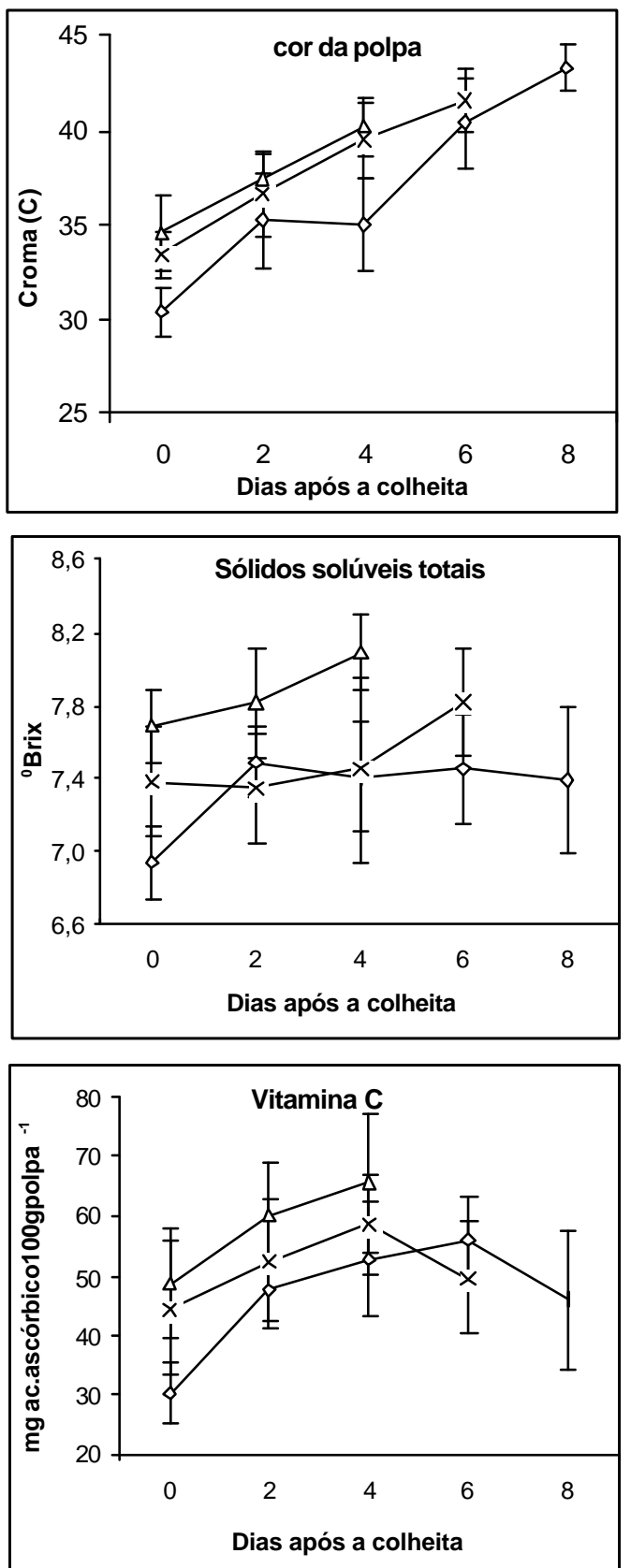

Figura 5- Influência dos estádios de maturação nas transformações físico-químicas durante o amadurecimento em goiabas 'Pedro Sato' colhidas em três estádios de maturação. (Estádio de maturação 1, 2 e 3, frutos colhidos com cor da casca verde-escura, verde-clara e verde-amarela, respectivamente). Barras verticais representam o desvio padrão, $\mathrm{n}=15$. 
O teor de ácido ascórbico apresentou comportamento semelhante ao da acidez total titulável. Verificou-se inicialmente um aumento no teor de ácido ascórbico para todos os estádios de maturação, com posterior diminuição. Jacomino (1999), trabalhando com goiabas brancas 'Kumagai' armazenadas a $10{ }^{\circ} \mathrm{C}$ em diferentes embalagens também observou aumento no teor de ácido ascórbico durante o amadurecimento dos frutos. Segundo Mercado-Silva et al. (1998), o aumento no teor de ácido ascórbico em goiabas durante o início do amadurecimento está associado ao aumento da síntese de intermediários metabólicos através da via pentoses fosfato, os quais são precursores doácido ascórbico. Com o decorrer do amadurecimento ocorreu a oxidação dos ácidos, levando a diminuição no teor de ácido ascórbico.

\subsubsection{Influência do estádio de maturação na qualidade pós-colheita de goiabas 'Pedro Sato'.}

O estádio de maturação no qual o fruto é colhido é um fator importante na determinação do período de comercialização (Chitarra \& Chitarra, 1990). Desta forma, a colheita dos frutos no início da maturação pode promover um aumento na vida de prateleira em relação aos frutos colhidos completamente maduros. Entretanto, a qualidade do fruto pode diminuir em função de distúrbios no processo de amadurecimento.

Com o avanço do processo de amadurecimento o fruto torna-se mais susceptível ao ataque de patógenos devido à diminuição da resistência da casca e da polpa, decorrente do amolecimento (Castro \& Sigrist, 1988). No final do período comercializável, o estádio 2 apresentou somente $6,7 \%$ de frutos com podridão. Entretanto, no sexto dia de análise a porcentagem de frutos com podridão foi de $77 \%$, o que inviabilizou o maior período de comercialização (Tabela 3).

A coloração dos frutos é um importante atributo de qualidade não só por contribuir para uma boa aparência, mas também, por influenciar a preferência do consumidor (Clydesdal, 1993). A variação do ângulo de cor entre o momento da colheita 
e o final do período comercializável foi de 11,97, 13,48 e 10,50 graus, para os estádios 1,2 e 3 respectivamente.

Os frutos colhidos no estádio 1 apresentaram, após seis dias, coloração da casca mais verde $\left({ }^{\circ} \mathrm{h} 107,20\right)$ do que os demais estádios, os quais apresentaram coloração amarela. Esta diferença, é devido muito provavelmente ao maior conteúdo de clorofila presente inicialmente nos frutos colhidos no estádio 1 (Tabela 3). Em goiabas indianas cv. Lucknow-49, Jain et al. (2001) observaram que o conteúdo de clorofila diminuiu de $1,45 \mathrm{mg} / 100 \mathrm{~cm}^{2}$ de fruto em goiaba verde-escura para $0,33 \mathrm{mg} / 100 \mathrm{~cm}^{2}$ em goiabas totalmente maduras.

A goiaba desenvolveu a coloração interna, apresentando no final do período comercializável, valores de croma superiores aos iniciais para todos aos estádios de maturação. O desenvolvimento da cor vermelha em goiaba é devido à biossíntese de licopeno, a qual aumenta no decorrer da maturação (Adulse \& Kadam, 1995). Ao final do período comercializável, o valor de croma foi menor nos frutos colhidos no estádio 3 do que os demais estádios (Tabela 3). Porém, observando a Figura 5, verifica-se que a tendência da curva relacionada a cor da polpa, para o estádio 3, é crescente. Desta forma, o menor valor verificado neste período não pode ser atribuído como característica de senescência, mas sim, ao menor tempo de armazenamento, o qual impossibilitou a visualização da intensidade máxima do croma.

A firmeza da polpa, não apresentou diferenças ao final do período comercializável (Tabela 3). Todos os estádios apresentaram intensa perda de firmeza no decorrer do armazenamento, estabilizando-se em valores entre 21,4 e 26,1 N. Durante o amadurecimento de goiabas, ocorre aumento da atividade de enzimas hidrolíticas como a poligalacturonase e pectinametilesterase (Mowlah \& Itto 1983; Jain et al., 2001). Este aumento promove intensa solubilização das pectinas constituintes da parede celular, resultando em rápida perda de firmeza.

Os teores de sólidos solúveis, acidez e ácido ascórbico são características que influenciam a qualidade organoléptica e nutricional da goiaba. No momento da colheita as goiabas do estádio 1 apresentaram menores teores de sólidos solúveis e ácido ascórbico do que o estádio 3 (Tabela 1). Porém, após o amadurecimento esta diferença 
desapareceu, devido a elevação nos teores destes nutrientes, principalmente no estádio 1 (Tabela 3). O pequeno aumento do teor de SST, ocorrido durante a armazenagem pode ser devido a conversão de amido em açúcares solúveis, conforme (Jain et al., 2001).

Em relação à acidez total titulável, a diferença observada nos frutos recém colhidos, manteve-se após o amadurecimento. Deste modo, as goiabas colhidas no estádio 1 apresentaram-se mais ácidas que as demais ao final do período de comercialização.

Tabela 3. Características físico-químicas de goiabas 'Pedro Sato' colhidas em três estádios de maturação e armazenadas a $25 \pm 1{ }^{\circ} \mathrm{C}$ e $85 \pm 5 \%$ UR.

\begin{tabular}{lcccc}
\hline & \multicolumn{3}{c}{ Estádios de maturação $^{-1}$} \\
\cline { 2 - 4 } Índices de maturação & Estádio 1 & Estádio 2 & Estádio 3 & C.V \\
& & & & $(\%)$ \\
\hline Número de dias após a colheita & 6 & 4 & 2 & \\
Cor da casca $\left({ }^{\circ}\right.$ h) & $107,20 \mathrm{a}$ & $101,55 \mathrm{~b}$ & $100,39 \mathrm{~b}$ & 4,3 \\
Firmeza $(\mathrm{N})$ & $26,1 \mathrm{a}$ & $21,4 \mathrm{a}$ & $24,9 \mathrm{a}$ & 30,1 \\
Cor da polpa (Croma) & $40,38 \mathrm{a}$ & $39,45 \mathrm{a}$ & $37,38 \mathrm{~b}$ & 4,9 \\
Sólidos solúveis totais $\left({ }^{\circ}\right.$ Brix) & $7,45 \mathrm{a}$ & $7,81 \mathrm{a}$ & $7,81 \mathrm{a}$ & 9,0 \\
Acidez Total Titulável $(\%$ ácido cítrico) & $0,62 \mathrm{a}$ & $0,53 \mathrm{~b}$ & $0,47 \mathrm{~b}$ & 13,3 \\
Vitamina C (mg ác. ascórbico/100g $\left.{ }^{-1}\right)$ & $56,02 \mathrm{a}$ & $58,52 \mathrm{a}$ & $60,02 \mathrm{a}$ & 14,1 \\
Relação SST/ATT & $12,28 \mathrm{a}$ & $15,04 \mathrm{~b}$ & $16,12 \mathrm{~b}$ & 14,4 \\
Frutos com podridão $(\%)$ & 27 & 6,7 & 20 & -
\end{tabular}

Médias seguidas pela mesma letra na linha não diferem entre si pelo teste de Tukey a 5\% de probabilidade.

${ }^{1}$ Estádio de maturação em função da cor da casca no momento da colheita: 1 = casca verde-escura; 2 =casca verde-clara; 3 = casca verde-amarela.

Em função do incremento nos teores de sólidos solúveis totais e na redução dos teores de acidez, observou-se aumento na relação: SST/ATT no decorrer do 
armazenamento. A relação: SST/ATT foi significativamente menor no estádio 1, indicando que os frutos colhidos neste estádio, mesmo após 6 dias de armazenamento, apresentam sabor mais ácido. Entre os estádios 2 e 3 não foram observadas diferenças significativas, indicando que os frutos nestes estádios encontram-se totalmente maduros ao final do período comercializável. Pois, segundo Reyes et al. (1976), a relação SST/ATT para frutos maduros é de 16,5.

\subsubsection{Análise Sensorial}

Para todos os atributos de qualidade analisados, observou-se a mesma escala de preferência, com notas decrescentes do estádio 3 para o estádio 1 (Figura 6).

O odor do fruto é um dos atributos utilizados pelo consumidor para aceitar ou rejeitar um produto. $\mathrm{O}$ odor de um fruto é devido, principalmente, a presença de compostos aromáticos específicos para cada produto. Sendo que a presença de odores estranhos indica desordens do metabolismo (Chitarra \& Chitarra, 1990).

Durante a maturação dos frutos, a produção de compostos voláteis sofre modificações, promovendo, diferenças no aroma. Goiabas imaturas contém níveis mais elevados de isobutanol, butanol e sesquiterpenes, os quais decrescem durante a maturação (Askar et al., 1986).

O fato de não ter havido diferenças significativas para o odor, indica que no momento da análise os frutos, provavelmente, apresentavam um nível de compostos aromáticos semelhantes, não sendo perceptível a distinção. Não foi identificada, pelos provadores, a presença de odores estranhos (fermentado, podre, etc...). As notas atribuídas para o odor, no estádio 3 foram levemente superiores às demais. Para os frutos deste estádio o odor foi classificado como muito bom (nota 6) por $45 \%$ dos provadores. Para os frutos colhidos no estádio 2, $40 \%$ dos provadores classificaram o odor como muito bom, enquanto que para o estádio 1, apenas $25 \%$ dos provadores atribuíram esta nota. Nos comentários efetuados pelos provadores, cerca de $40 \%$ referiram-se à presença de odor característico, porém pouco intenso, o que explica as notas não terem sido maiores para este estádio. 
Em relação ao sabor, não foram verificadas diferenças significativas entre o os frutos colhidos nos estádios 1 e 2 . Somente o estádio 3 mostrou-se significativamente diferente dos demais estádios (Apêndice- Tabela 1).

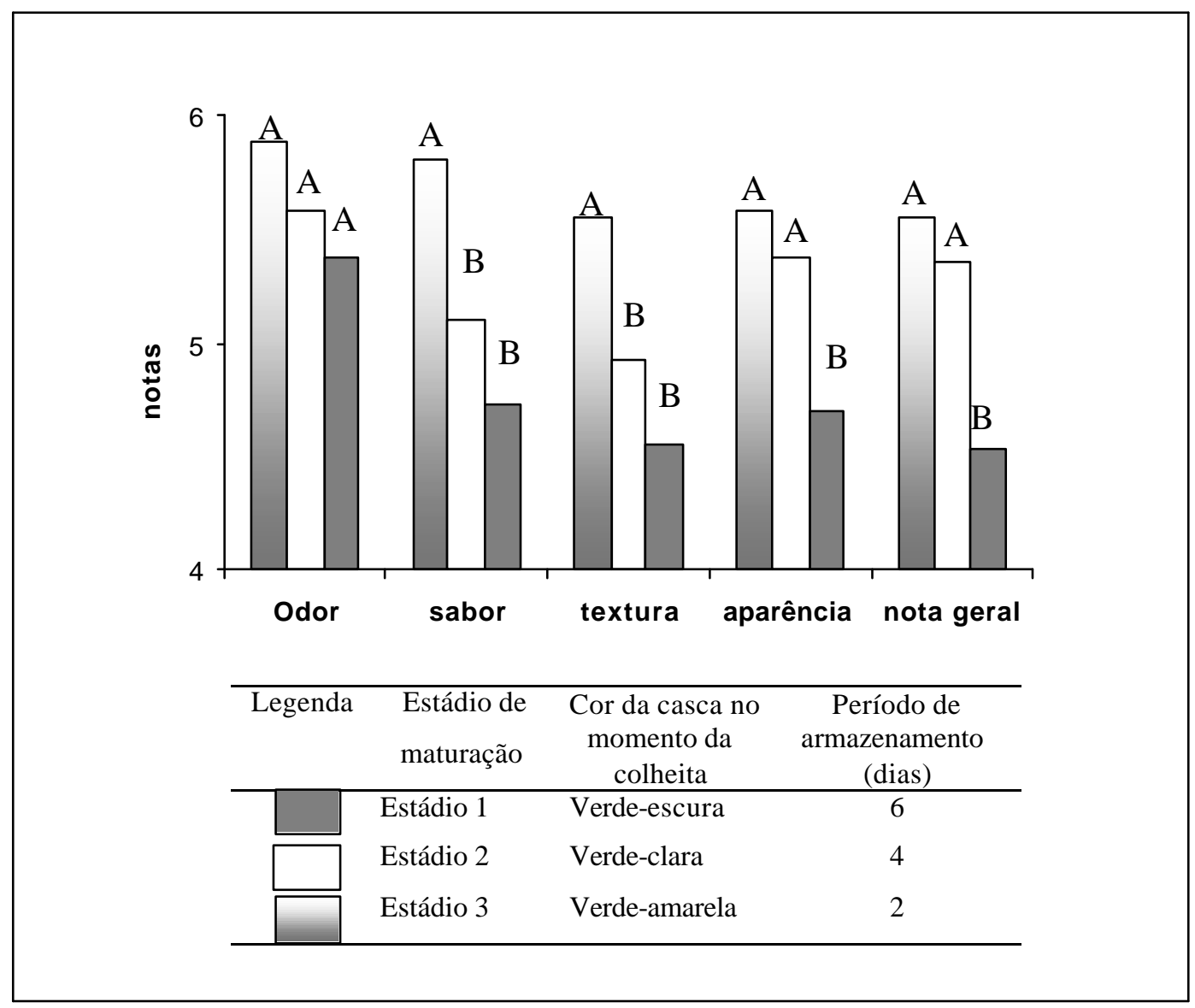

Figura 6- Análise sensorial de goiabas 'Pedro Sato' colhidas em três estádios de maturação e armazenadas a $25 \pm 1^{\circ} \mathrm{C}$ até completo amadurecimento. (Notas: $1=$ péssimo; 2 = muito ruim; 3 = ruim; 4 = regular; $5=$ bom; $6=$ muito boa; 7 = ótima). Médias seguidas de mesma letra não diferem entre si pelo teste de Tukey a 5\% de probabilidade.

O sabor de um fruto é dado, principalmente, pelo conteúdo de açúcares e ácidos orgânicos, sendo que o sabor adstringente de alguns frutos é atribuído a presença de compostos fenólicos (Tuker, 1993). Comparando-se os resultados obtidos na análise 
sensorial, com os dados obtidos nas análises físico-químicas (tabela 3), verifica-se que as pequenas variações nos teores sólidos solúveis totais e acidez total titulável foram perceptíveis, promovendo a distinção do sabor entre os estádios.

A relação entre SST/ATT confirma, de modo mais significativo, os resultados obtidos na análise sensorial. A relação de 16,12 observada no estádio 3 , foi a que conferiu melhor sabor aos frutos, segundo a análise sensorial. Estes resultados indicam que os frutos colhidos nos estádios 1 e 2, apresentam sabor inferior ao dos frutos colhidos no estádio mais maduro (estádio 3), mesmo ao final do período comercializável, no qual as diferenças físico-químicas entre os estádios foram reduzidas pelo amadurecimento.

Apesar da firmeza da polpa não ter apresentado diferenças significativas entre os estádios, ao final do período comercializável (tabela 3), foram verificadas diferenças em relação a textura na análise sensorial. Os frutos nos estádios 1 e 2 obtiveram notas médias para a textura, de 4,55 e 4,85, respectivamente, sendo consideradas regulares, enquanto que a textura dos frutos do estádio 3 foi considerada boa (valor médio 5,55).

Em relação à aparência foram avaliados aspectos relacionados à coloração da casca, presença de lesões por danos mecânicos e/ou podridões, brilho e aspecto de frescor. Para o estádio 1, a aparência foi regular, sendo significativamente diferente da aparência dos estádios 2 e 3, classificados em média como bons. Os menores valores obtidos para o estádio 1 foram função da menor homogeneidade da coloração e do menor aspecto de frescor dos frutos.

$\mathrm{Na}$ aparência global avaliaram-se aspectos relacionados a aparência externa juntamente com os demais atributos representando uma nota da qualidade total do fruto. Foi verificada diferença somente entre o estádio 1 e os demais.

A análise sensorial demonstrou que os frutos colhidos no estádio 3 e armazenados durante dois dias apresentam qualidade sensorial superior aos frutos colhidos nos estádio 1 e 2 e armazenados durante seis e quatro dias, respectivamente. Isto demonstra que o processo de amadurecimento dos frutos colhidos nestes estádios não permitiu que estes atingissem a mesma qualidade daqueles colhidos em estádio mais avançado de maturação. 
Desta forma, a colheita em estádio verde-escuro só é justificável quando a conservação em condição ambiente para longo período for inevitável. A implementação de técnicas de conservação na cadeia produtiva desta fruta que permita ampliar o tempo de conservação de goiabas colhidas em estádio de maturação mais avançado é indispensável, visando melhorar a qualidade da fruta ao consumidor. 


\subsection{CONCLUSÃO}

- A cor da casca, a firmeza da polpa e a relação: sólidos solúveis totais/acidez total titulável são bons indicadores do estádio de maturação em goiabas 'Pedro Sato'.

- Os teores de sólidos solúveis totais, de acidez total titulável e de ácido ascórbico não são bons indicadores do estádio de maturação em goiabas.

- Goiabas 'Pedro Sato', colhidas em diferentes estádios de maturação, apresentam comportamento semelhante quanto às transformações físico-químicas, porém não atingem a mesma qualidade sensorial ao final do amadurecimento.

- Goiabas 'Pedro Sato', colhidas no estádio de maturação 3 (cor da casca verdeamarela), apresentam qualidade sensorial superior àquelas colhidas no estádio 2 (cor da casca verde-clara) ou estádio 1 (cor da casca verde-escura). 


\section{RESUMO:}

O conhecimento do padrão respiratório dos frutos é fundamental para o controle do amadurecimento. Com o objetivo de determinar o padrão respiratório de goiabas 'Pedro Sato', foram realizados dois experimentos. No primeiro experimento, foram utilizados frutos em três estádios de maturação: Estádio 1- cor da casca verde-escura; Estádio 2 cor da casca verde-clara; Estádio 3- cor da casca verde-amarela. Os frutos foram tratados com fungicida prochloraz (0,250mg. $\left.{ }^{-1}\right)$ armazenados em câmaras com a $23 \pm 1^{\circ} \mathrm{C}$ e $85 \pm$ $5 \%$ UR, e analisados durante 12 dias. No segundo experimento, foram utilizados frutos no estádio de maturação 2 (cor da casca verde-clara). Após tratamento com fungicida prochloraz $\left(0,250 \mathrm{mg} .1^{-1}\right)$, os frutos foram separados em três lotes para aplicação dos tratamentos: controle; 1-MCP (300nl I $1^{1}, 12$ horas de aplicação) e etileno (1000 $\mu 1.1^{-1}, 24$ horas de aplicação).. No primeiro experimento verificou-se aumento da atividade respiratória e da produção de etileno caracterizando o padrão climatérico de amadurecimento, independente do estádio de maturação. A máxima atividade respiratória e de produção de etileno ocorreram após o completo amadurecimento. No segundo experimento, a aplicação de 1-MCP promoveu a redução da atividade respiratória e da produção de etileno, retardando o amadurecimento dos frutos. As transformações da cor da casca, da polpa e da firmeza da polpa também foram afetadas. Os frutos não responderam à aplicação de etileno.

Palavras-chaves: Psidium guajava, climatério, amadurecimento, etileno. 


\section{RESPIRATORY PATTERN OF GUAVAS 'PEDRO SATO',}

\section{SUMMARY}

The knowledge of the respiratory pattern of the fruits is fundamental for ripening control. Two experiments were accomplished with the objective of determining the respiratory pattern of guavas ' Pedro Sato '. In the first experiment, guavas were used in three maturation stages: Stage 1- dark green peel; Stage 2- light green peel; Stage 3yellowish green peel. The guavas were treated with fungicidal prochloraz $(0,250 \mathrm{mg}$. 11) stored in chamber $23 \pm 1^{\circ} \mathrm{C}$ and $85 \pm 5 \% \mathrm{RH}$, and analyzed for 12 days. In the second experiment, guavas were used in the stage of maturation 2 (light green peel). After treatment with fungicidal prochloraz $\left(0,250 \mathrm{mg}\right.$. $\left.\mathrm{I}^{-1}\right)$, the guavas were separated in three lots for application of the treatments: control; 1-MCP $\left(300 \mu \mathrm{g} . \mathrm{I}^{-1}, 12\right.$ hours of application), and ethylene (1000 $\mu \mathrm{g} . \mathrm{I}^{-1}, 24$ hours of application). In the first experiment there was an increase in respiratory activity and in the ethylene production characterizing the standard ripening climacteric, regardless of the maturation stage. The maximum respiratory activity and of ethylene production occurred after the complete ripening. In the second experiment, the application of 1-MCP promoted the reduction the respiratory activity and in ethylene production, resultting ripening delay of the fruits. The transformations in peel and pulp color and pulp firmness were also affected. The fruit did not response to ethylene applications.

Palavras-chaves: Psidium guajava, pattern respiratory, ripening, etylene. 


\subsection{INTRODUÇÃO}

O amadurecimento dos frutos corresponde a uma série de mudanças fisiológicas, bioquímicas e estruturais que tornam $\mathrm{o}$ fruto atrativo para $\mathrm{o}$ consumo. $\mathrm{O}$ amadurecimento é frequientemente indicado pelas: mudanças na cor, na degradação parcial e solubilização da parede celular, produção de compostos voláteis, acúmulo de açúcares, degradação de ácidos orgânicos e diminuição de alcalóides (Rhodes, 1980).

Os frutos são geralmente divididos em dois grupos de acordo com seu padrão respiratório: climatéricos e não-climatéricos. Em frutos climatéricos como banana e tomate, o começo do amadurecimento está associado a um aumento da atividade respiratória e da biossíntese de etileno. Frutos como morango e citros não apresentam aumento da atividade respiratória e da produção de etileno durante o amadurecimento, sendo classificados como não-climatéricos.

As informações sobre o padrão respiratório de goiabas (Psidium guajava L.) são contraditórias. Botelho (1996) sugere que esta seria uma característica varietal. Alguns autores consideram a goiaba como um fruto não-climatérico (Biale \& Barcus, 1970; Medina, 1978; Chitarra \& Chitarra, 1990). Porém, para Akamine \& Goo (1979), Brown \& Wills (1983), Oliveira (1996), Mercado-Silva et al. (1998), a goiaba é um fruto climatérico. Em relação à variedade 'Pedro Sato' os trabalhos apresentam algumas divergências. Para Lima et al. (1998), a variedade é climatérica e, quando colhida no estádio 'de vez', apresenta pico respiratório três dias após a colheita. Entretanto, Mattiuz (2002), observou que goiabas 'Pedro Sato', colhidas em estádio 'de vez' e armazenadas a temperatura ambiente, tiveram aumento constante da atividade respiratória até sete dias após a colheita, período em que os frutos apresentaram elevado grau de senescência.

O comportamento respiratório e da intensidade de respiração podem ser usados como indicadores das condições de armazenamento necessárias para aumentar a vida útil do fruto após a colheita. A manipulação do amadurecimento é importante para garantir a extensão do período de comercialização dos produtos, sendo que para isto o conhecimento da fisiologia pós-colheita é indispensável (Awad, 1993). 
O objetivo deste trabalho foi determinar o padrão respiratório de goiabas 'Pedro Sato', afim de melhor entender o processo de amadurecimento, e desta forma contribuir para o desenvolvimento de tecnologias de conservação pós-colheita. 


\subsection{MATERIAL E MÉTODOS}

\subsubsection{Experimento I}

Foram utilizadas goiabas da variedade 'Pedro Sato' provenientes de pomar comercial localizado no município de Vista Alegre, SP. Os frutos foram classificados em três estádios de maturação em função da cor da casca:

Estádio 1- cor da casca verde-escura, ângulo de cor $\left({ }^{\circ} \mathrm{h}\right)$ entre 120 e 117;

Estádio 2- cor da casca verde-clara, ângulo de cor $\left({ }^{\circ} \mathrm{h}\right)$ entre 116 e 113;

Estádio 3- cor da casca verde-amarela ângulo de cor $\left({ }^{\circ} \mathrm{h}\right)$ entre 112 e 108.

Após a seleção na casa de embalagem, os frutos foram individualmente envoltos em papel manteiga, acondicionados em caixas de papelão e transportados para Laboratório de Pós-colheita do Departamento de Produção Vegetal ESALQ, PiracicabaSP. No laboratório, os frutos foram novamente selecionados de forma a obter lotes homogêneos quanto aos estádios de maturação e sem defeitos.

Os frutos foram tratados com fungicida prochloraz na concentração de 0,250mg. ${ }^{-1}$, por meio de imersão em solução durante 3 minutos. Segundo Ojeda (2001), o fungicida prochloraz não interfere no processo de amadurecimento de goiabas 'Pedro Sato' e tem bom controle do desenvolvimento de podridões na pós-colheita destes frutos. A utilização de fungicida foi necessária para evitar a interferência do desenvolvimento de podridões nas análises de respiração e síntese de etileno.

Os frutos foram armazenados em câmaras com temperatura de $23 \pm 1{ }^{\circ} \mathrm{C}$ e $85 \pm 5$ $\%$ UR. 


\section{- $\quad$ Análises físico-químicas}

As variáveis analisadas foram:

a) Cor da casca: determinada com o colorímetro Minolta, modelo CR-300, tomando-se 2 leituras por fruto, em lados opostos da sua região equatorial. Os resultados foram expressos em ângulo de cor $\left({ }^{\circ} \mathrm{h}\right)$;

b) Cor da polpa: determinada com o colorímetro Minolta, modelo CR-300, tomando-se 1 leitura no centro do fruto, os quais foram cortados transversalmente. Os resultados foram expressos em cromaticidade $(\mathrm{C})$;

c) Firmeza da polpa: determinada com penetrômetro digital, ponteira plana de $8 \mathrm{~mm}$ de diâmetro, tomando-se duas leituras por fruto em lados opostos de sua região equatorial. Os resultados foram expressos em Newtons $(\mathrm{N})$;

d) Teor de sólidos solúveis totais (SST): determinado por leitura direta em refratômetro digital marca Atago. Os resultados foram expressos em ${ }^{\circ}$ Brix;

e) Acidez total titulável (ATT): determinada de acordo com metodologia descrita por Carvalho et al. (1990). Os resultados foram expressos em \% de ácido cítrico na polpa;

f) Teor de vitamina $\mathrm{C}$ determinado de acordo com metodologia descrita por Carvalho et al. (1990), os resultados foram expressos em mg de ácido ascórbico100g polpa ${ }^{-1}$.

As análises foram realizadas a cada dois dias durante 12 dias. $\mathrm{O}$ delineamento experimental foi inteiramente casualizado, com 3 tratamentos (estádio de maturação 1, 2 e 3$)$ e 4 repetições compostas de 3 frutos para cada dia de análise $(0 ; 2 ; 4 ; 6 ; 8 ; 10 ; 12)$.

\section{- Atividade respiratória e produção de etileno}

A atividade respiratória e a produção de etileno foram determinadas a cada 12 horas utilizando-se 10 repetições compostas de 1 fruto para cada estádio de maturação.

A atividade respiratória foi determinada pela quantificação da produção de $\mathrm{CO}_{2}$, dos frutos. Os frutos foram colocados, individualmente, em frascos com capacidade de $590 \mathrm{ml}$, os quais foram hermeticamente fechados durante 1 hora. Após este período, 
foram retiradas as amostras de gases para a quantificação de $\mathrm{CO}_{2}$ e etileno através de um septo de silicone existente na tampa. O conteúdo de $\mathrm{CO}_{2}$ do interior do frasco foi determinado em analisador de gases PBI dansensor 9900. Os resultados foram expressos em $\mathrm{mlCO}_{2} \cdot \mathrm{kg}^{-1} \cdot \mathrm{h}^{-1}$. Os frascos foram abertos logo após a retirada das amostras.

Para a determinação de etileno, a amostra de gás foi retirada com auxílio de uma seringa e imediatamente transferida para frascos de $17 \mathrm{ml}$, os quais foram hermeticamente fechados. Esta etapa de transferência foi realizada imergindo-se a seringa e o frasco em água, de modo a evitar a contaminação por ar atmosférico, ou perda de gás da amostra. Os frascos, contendo as amostras, foram levados para o Departamento de Fisiologia Vegetal da UNICAMP (Campinas, SP) onde foram efetuadas as análises. $\mathrm{O}$ teor de etileno na amostra foi determinado injetando-se $0,5 \mathrm{ml}$ da mesma em aparelho de cromatografia gasosa (Shimadzu GC-14B) com detector de ionização de chama, utilizando-se uma coluna "HayeSepT". O gás de arraste utilizado foi $\mathrm{N}_{2}$, a um fluxo de $20 \mathrm{ml} /$ minuto. As temperaturas mantidas no aparelho foram $80^{\circ} \mathrm{C}$ para a coluna, $100^{\circ} \mathrm{C}$ no injetor e $150^{\circ} \mathrm{C}$ no detector. Como padrão foi utilizando etileno $\left(1 \mu \mathrm{l} \mathrm{C}_{2} \mathrm{H}_{4} \cdot \mathrm{Kg} \cdot \mathrm{h}^{-1}\right)$. Os resultados foram expressos em $\mu \mathrm{lC}_{2} \mathrm{H}_{4} \cdot \mathrm{kg}^{-1} \cdot \mathrm{h}^{-1}$.

\section{- Análise dos dados}

Com o objetivo de analisar a influência dos estádios de maturação nos processos bioquímicos e fisiológicos após a colheita foram avaliadas as taxas de variação (declividade da curva estimada) das variáveis físico-químicas analisadas.

$\mathrm{O}$ monitoramento das transformações das variáveis (y) no decorrer do tempo (t), possibilitou a estimativa, por regressão simples, de equações da forma $y=f(t)$. A velocidade de transformação destas variáveis no tempo pode ser avaliada, segundo a análise das taxas de variação (Tx), definida como a primeira derivada (dy/dt), no ponto desejado. A taxa de variação pode ser calculada algebricamente $(\operatorname{tg} \alpha)$, sendo $\alpha$, o ângulo formado pela reta tangente à curva estimada, ou pela derivada primeira neste ponto, dy/dt. 
A partir dos dados das variáveis físico-químicas determinou-se o modelo matemático mais adequado, p.ex. $y=a t^{b}$, e para os intervalos de interesse $\left(t_{1}, t_{2}, t_{3}\right)$, avaliou-se o valor de dy/dt. Por exemplo, se dy/dt $3>d y / d_{2}>d y / d t_{1}$, então $\mathrm{Tx}_{3}>\mathrm{Tx}_{2}>\mathrm{Tx}_{1}$.

Assim, o processo de transformação referente a variável será mais intenso, quanto maior for sua taxa naquele momento.

Desta maneira, foi necessário estimar as equações para as variáveis de interesse em cada estádio de maturação. Para isto, foi realizada uma análise de regressão simples a partir dos dados obtidos em laboratório. Os dados utilizados para análise de regressão foram resultado de 4 repetições, para os diferentes tempos de análise $(0,2,4,6,8,10,12$ dias após a colheita).

Os dados obtidos também foram submetidos à análise do desvio padrão. As diferenças entre dois tratamentos maior que a soma de dois desvios padrões foram consideradas significativas.

\subsubsection{Experimento II}

Foram utilizados somente frutos no estádio de maturação 2 (cor da casca verdeclara, ângulo de cor entre 116 e 113). Os frutos foram colhidos em pomar comercial na região de Monte Alto, SP. Após a colheita, os frutos foram imediatamente transportados para o laboratório de Pós-colheita do Departamento de Produção Vegetal da ESALQ em Piracicaba (SP).

Os frutos foram tratados com fungicida por meio de imersão em solução de Prochloraz na concentração de $0.250 \mathrm{mg} . \mathrm{I}^{-1}$, durante 3 minutos. Posteriormente, os frutos foram divididos em três lotes e colocados em caixas herméticas para a aplicação dos tratamentos: controle, 1-MCP (1-metilciclopropeno) e etileno (Tabela 1).

O etileno $\left(1000 \mu 1.1^{1}\right)$ foi aplicado injetando-se gás azetil (5\% de etileno) no interior da caixa hermética. Após 12 horas a caixa foi aberta afim de não comprometer o nível de $\mathrm{O}_{2}$. Aproximadamente após 3 minutos, a caixa foi novamente fechada e o etileno reaplicado. 
Para a aplicação de 1-MCP na concentração de 300nl. ${ }^{-1}$ foi utilizado $0,089 \mathrm{~g}$ do produto comercial SmartFresh, o qual foi dissolvido em $20 \mathrm{ml}$ de água a $50^{\circ} \mathrm{C}$ em frasco hermeticamente fechado. Após completa dissolução do produto, o frasco foi aberto no interior da caixa para o tratamento dos frutos.

Após os tratamentos, os frutos foram retirados das caixas e armazenados em câmaras à temperatura de $23 \pm 1^{\circ} \mathrm{C}$ e $85 \pm 5 \%$ UR. Foram efetuadas análises diárias da produção de etileno e da atividade respiratória, utilizando-se a mesma metodologia descrita no experimento I. A primeira análise foi efetuada 24 horas após a colheita, logo após a retirada dos tratamentos.

Tabela 1. Tratamentos aplicados em goiabas 'Pedro Sato' após a colheita em temperatura de $23 \pm 1{ }^{\circ} \mathrm{C}^{1}$.

\begin{tabular}{ccc}
\hline Tratamento & Concentração & Período de exposição \\
\hline $1-\mathrm{MCP}$ & $300 \mathrm{nl}^{-1} \mathrm{I}^{-1}$ & 12 horas \\
Etileno & $1000 \mu 1 . \mathrm{I}^{-1}$ & 24 horas \\
Controle & $---\cdot-----$ & 12 horas $^{2}$ \\
\hline
\end{tabular}

Durante a aplicação dos tratamentos a concentração de $\mathrm{CO}_{2}$ no interior das caixas não ultrapassou $2,5 \%$.

${ }^{2}$ Os frutos foram mantidos em caixa fechada durante 12 horas, com o objetivo de manter o mesmo ambiente dos demais tratamentos.

As análises físico-químicas da cor da casca, cor da polpa e firmeza da polpa foram realizadas a cada três dias, conforme a metodologia descrita para o experimento I. Entretanto, foram utilizadas 3 repetições de 3 frutos para cada tratamento (controle; 1MCP; etileno) e dia de análise $(0 ; 3 ; 6 ; 9 ; 12 ; 15$ dias após a colheita). 


\subsection{RESULTADOS E DISCUSSÃO}

\subsubsection{Experimento I}

\subsubsection{Atividade respiratória e produção de etileno}

Observou-se aumento gradual da atividade respiratória no decorrer do armazenamento para todos os estádios de maturação. A atividade máxima ocorreu aos 8,5; 10,5 e 11,5 dias após a colheita, para os frutos colhidos nos estádios 3, 2 e 1, respectivamente (Figura 1).

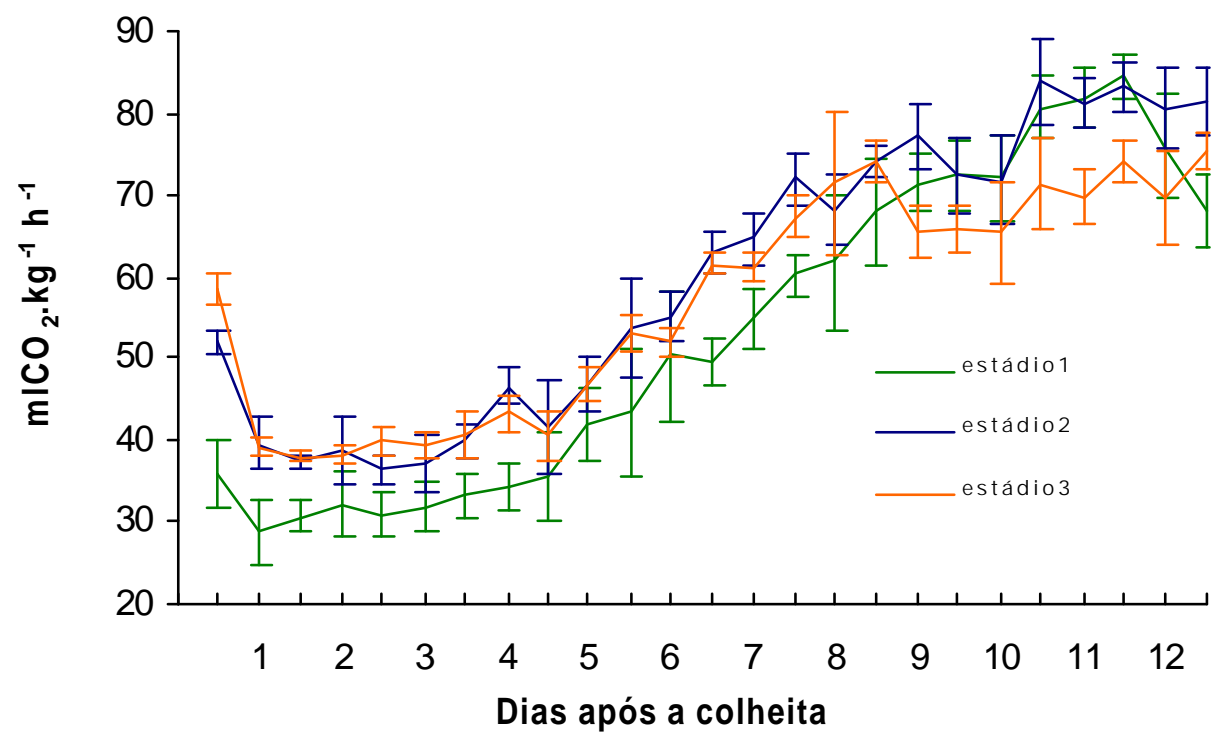

Figura 1- Atividade respiratória de goiabas 'Pedro Sato' colhidas em diferentes estádios de maturação e armazenadas a $23 \pm 1^{\circ} \mathrm{C}$ e 85-90 \% UR. (Estádio de maturação 1, 2 e 3, frutos colhidos com cor da casca verde-escura, verde-clara e verdeamarela, respectivamente). As barras verticais indicam o desvio padrão, $n=10$. 
A primeira análise foi realizada logo após o transporte dos frutos, o que possivelmente promoveu a maior atividade respiratória neste período. Os frutos colhidos nos estádios 1, 2 e 3 apresentaram atividade respiratória mínima de 29, 40 e 39 $\mathrm{mlCO}_{2} \cdot \mathrm{kg}^{-1} \cdot \mathrm{h}^{-1}$, respectivamente. A respiração foi praticamente estável até o quarto dia após a colheita, a partir do qual verificou-se aumento acentuado da atividade respiratória, com posterior diminuição, em todos os estádios de maturação. Os valores máximos obtidos foram de $85 \mathrm{mlCO}_{2} \mathrm{~kg}^{-1} \cdot \mathrm{h}^{-1}$ nos estádios $1 \mathrm{e} 2$, e de $74 \mathrm{mlCO}_{2} \mathrm{~kg}^{-1} \cdot \mathrm{h}^{-1}$ nos estádios 1, 2 e 3, respectivamente (Figura 1). Estes valores são superiores aos obtidos por Oliveira (1996), para goiabas 'Kumagai'. Segundo o autor, o pico respiratório foi de $51,38 \mathrm{mlCO} \cdot \mathrm{kg}^{-1} \cdot \mathrm{h}^{-1}$ ocorreu nove dias após a colheita. Botelho (1996), também em goiabas 'Kumagai', observou atividade máxima de aproximadamente $55 \mathrm{mg} \cdot \mathrm{CO}_{2} \cdot \mathrm{kg}^{-1} \cdot \mathrm{h}^{-1}$ sete dias após a colheita. Em goiabas 'Pedro Sato', Lima et al. (1998), observaram que frutos colhidos no estádio verde e "de vez" apresentaram máxima atividade respiratória de $17,46 \mathrm{mgCO}_{2} \cdot \mathrm{kg}^{-1} \cdot \mathrm{h}^{-1}$, quatro dias após a colheita e de $12,30 \mathrm{mgCO} 2 \cdot \mathrm{kg}^{-1} \mathrm{~h}^{-1}$, três dias após a colheita, respectivamente. MercadoSilva et al. (1998), verificaram aumento acentuado da atividade respiratória em goiabas 'Media China', com pico ocorrendo entre quatro e cinco dias após a colheita, em função do estádio de maturação e da época de colheita.

Em função do aumento da atividade respiratória apresentada pelos frutos após a colheita (Figura 1), a variedade 'Pedro Sato' pode ser classificada como climatérica, pois, por definição são considerados frutos climatéricos aqueles que apresentam aumento da atividade respiratória durante o amadurecimento (Rhodes, 1980; Yang, 1985; Leliévre et al., 1997).

O aumento da respiração, durante o amadurecimento de frutos climatéricos, é entendido como uma resposta homeostática da mitocôndria em uma tentativa de compensar os danos causados à célula em função do aumento do metabolismo decorrente da produção autocatalítica do etileno (Romani, 1984). A diminuição da respiração na fase considerada pós-climatérica representa a perda da capacidade homeostática da mitocôndria, tornando assim predominante os processos de senescência. 
A intensidade de respiração é um dos fatores determinantes na longevidade das frutas após a colheita, considerando que a respiração é um processo oxidativo das substâncias de reserva, levando o órgão a senescência (Wills et al., 1998).

A atividade respiratória foi elevada desde o início do armazenamento, o que pode explicar a rápida senescência da goiaba. O mamão, um fruto climatérico com elevado grau de perecilibilidade, apresenta atividade respiratória entre 20 a $45 \mathrm{mlCO}_{2} \cdot \mathrm{kg}^{-1} \cdot \mathrm{h}^{-1}$ à $25{ }^{\circ} \mathrm{C}$ (Biale, 1960). Porém, frutos climatéricos como ameixa e pêra, que apresentam menor atividade respiratória, têm menor grau perecibilidade.

A produção de etileno teve comportamento semelhante à atividade respiratória, com aumento gradual, para todos os estádios de maturação. A produção de etileno, 12 horas após a colheita, para os estádios 1,2 e 3 foi de 0,$42 ; 1,44$ e 1,51 $\mu \mathrm{lC}_{2} \mathrm{H}_{4} \mathrm{~kg}^{-1} \cdot \mathrm{h}^{-1}$ para os estádios 1, 2 e 3 respectivamente (Figura 2) .O pico de etileno ocorreu em torno de nove dias para os estádio de maturação 1 e 2 e aos oito dias após a colheita para o estádio 3. No estádio 1 o pico de produção foi $3,25 \mu \mathrm{lC}_{2} \mathrm{H}_{4} \mathrm{~kg}^{-1} \cdot \mathrm{h}^{-1}$ e para os estádios 2 e 3 a máxima produção foi de $3,70 \mu \mathrm{lC}_{2} \mathrm{H}_{4} \mathrm{~kg}^{-1} \cdot \mathrm{h}^{-1}$.

A produção de etileno apresentou valores semelhantes aos obtidos por Akamine \& Goo (1979) para as cultivares 'Beaumont', 'Yellow strawberry', 'White guava' e 'Strawberry guava'.

A menor produção de etileno no estádio 1, possivelmente, seja devido a menor sensibilidade dos frutos a este fitohormônio, em função do estádio de desenvolvimento do fruto (Yang, 1985). A menor sensibilidade está relacionada ao menor número de sítios receptores presentes no tecido. Segundo Yen et al. (1995), o número de receptores aumenta durante o amadurecimento, permitindo o aumento da ação do etileno e a contínua produção autocatalítica.

O aumento da produção de etileno durante o amadurecimento é devido à produção autocatalítica, sendo típica de frutos climatéricos (McMurchie et al., 1972). Em frutos climatéricos, o etileno promove a síntese das enzimas de sua própria via biossintética, levando assim ao aumento crescente de sua produção durante o amadurecimento (Yang, 1985; Atta-Aly et al., 2000). A produção autocatalítica de etileno está presente somente nos frutos climatéricos. Desta forma, em função dos dados 
obtidos de produção de etileno, bem como dos dados de atividade respiratória, verificase que a goiaba 'Pedro Sato' é uma variedade climatérica, corroborando com Lima et al. (1998), que também a classificam desta forma.

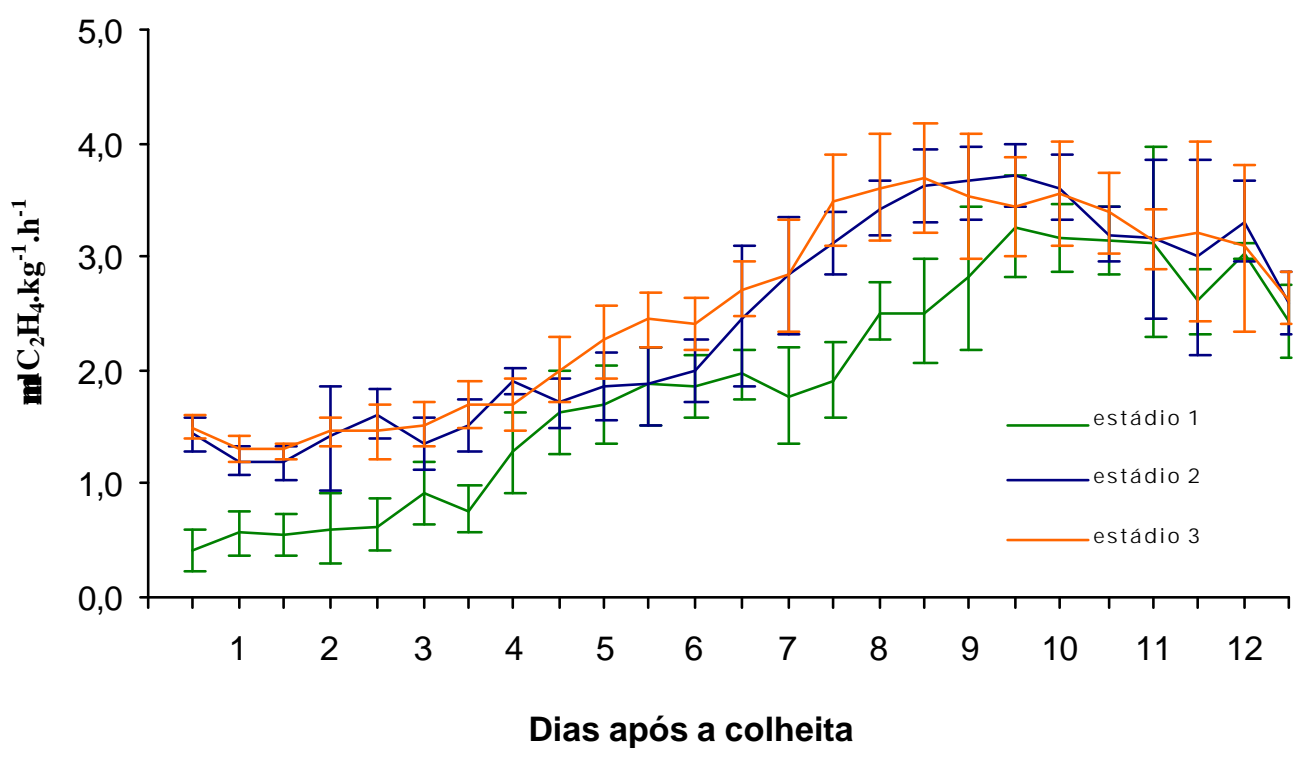

Figura 2- Produção de etileno em goiabas 'Pedro Sato' colhidas em três estádios de maturação e armazenadas a $23 \pm 1{ }^{\circ} \mathrm{C}$ e $85 \pm 5 \%$ UR. (Estádio de maturação 1, 2 e 3, frutos colhidos com cor da casca verde-escura, verde-clara e verdeamarela, respectivamente). As barras verticais indicam o desvio padrão, $n=10$. 


\subsubsection{Transformações físico-químicas e a relação com a produção de etileno.}

$\mathrm{Na}$ literatura, é amplamente descrito que o amadurecimento é uma fase do desenvolvimento dos frutos, na qual ocorre com uma sequiência integrada de transformações na textura, na coloração, no aroma, na acidez, entre outras mudanças fisiológicas e bioquímicas. Estas mudanças transformam um fruto fisiologicamente maturo, porém não comestível, em um fruto palatável e visualmente atrativo. A regulação do início destas mudanças, em frutos climatéricos, é atribuída ao aumento da biossíntese autocatalítica de etileno (Yang, 1985; Mattoo \& Suttle, 1991; Tucker, 1993; Giovanoni, 2001). O aumento da produção de etileno controla o amadurecimento de frutos climatéricos pela ativação de muitos genes responsáveis pelas mudanças fisicoquímicas, (Oiteker \& Yang, 1995). Em goiabas 'Pedro Sato' observou-se que, um pequeno aumento na produção de etileno foi responsável por intensas mudanças principalmente na cor da casca e firmeza, para os três estádios de maturação (Figura 3 e 4).

Cor da casca: a diminuição no ângulo de cor $\left({ }^{\circ} h\right)$ da cor da casca indica a mudança da cor verde para amarela. Os frutos colhidos no estádio 1 mantiveram, durante todo o período de avaliação, diferenças significativas em relação aos demais estádios de maturação. A maior amplitude de variação foi verificada logo após a colheita, para todos os estádios (Figura 3). Os frutos colhidos no estádio 1 apresentaram dois períodos de intensa mudança de coloração. Entre dois e quatro dias ocorreram $42 \%$ do total da mudança de cor e entre oito e dez dias ocorreu cerca de $45 \%$ do total da variação do ângulo de cor. Nos estádios 2 e 3 o período em que ocorreu maior mudança de coloração foi entre dois e quatro dias após a colheita. A mudança de coloração é mais rápida no início do armazenamento, para todos os estádios de maturação, diminuindo no decorrer do tempo. Este fato pode ser melhor visualizado observando-se os valores das taxas de variação referentes a cor da casca, as quais foram decrescentes ao longo do armazenamento em todos os estádios de maturação (Tabela 2). 
A intensa mudança de coloração da casca ocorreu antes do pico de etileno. O processo de transformação da coloração está intimamente ligado a biossíntese de etileno. O etileno promove o aumento da atividade das enzimas clorofilases responsáveis pela degradação da clorofila e, também induz a síntese de novas enzimas responsáveis pela biossíntese de carotenóides (Wills et al., 1998).

No estádio 1, a produção inicial de etileno menor que $0,5 \mu \mathrm{lC}_{2} \mathrm{H}_{4} \mathrm{~kg}^{-1} \mathrm{~h}$, nos primeiros dias após a colheita, possivelmente foi suficiente para desencadear o processo de mudança de coloração em goiabas, visto a mudança da cor verificada entre zero e dois dias após a colheita. O etileno é fisiologicamente ativo em concentrações muito baixas. Abeles et al. (1992) reporta que a concentração de $0,01 \mu 11^{-1}$ representa a concentração mínima de etileno capaz de promover uma resposta fisiológica. Isto pode explicar a mudança da coloração em goiaba mesmo o etileno estando em baixas concentrações. Contudo, a sensibilidade de um tecido ao etileno depende do estádio de desenvolvimento e do tipo de tecido. 

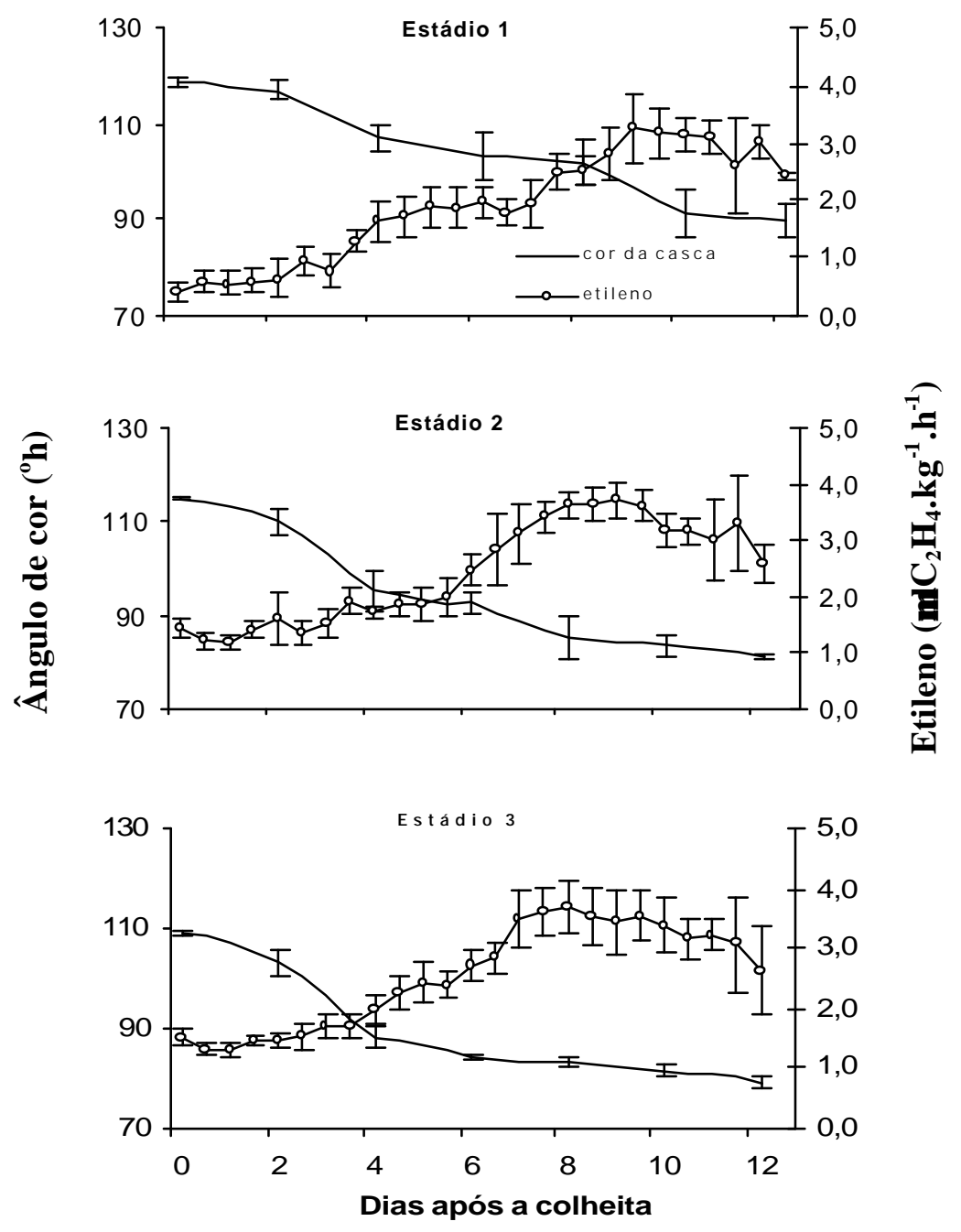

Figura 3- Produção de etileno e mudanças da cor da casca em goiabas 'Pedro Sato' colhidas em diferentes estádios de maturação e armazenadas a $23 \pm 1{ }^{\circ} \mathrm{C}$ e 85 $\pm 5 \%$ UR. (Estádio de maturação 1, 2 e 3, frutos colhidos com cor da casca verde-escura, verde-clara e verde-amarela, respectivamente). 
Firmeza da polpa: todos os estádios apresentaram intensa perda de firmeza acompanhada de um aumento gradual da produção de etileno. Porém, a máxima produção de etileno coincidiu com o período que a perda de firmeza tornou-se praticamente estável (Figura 4). A firmeza apresentou taxas elevadas nos primeiros dias após a colheita, demonstrando que esse processo ocorreu mais rapidamente nos primeiros quatro dias após a colheita para todos os estádios de maturação. No estádio 1, a mudança de firmeza ocorreu mais rapidamente que nos demais estádios. No início do armazenamento, a taxa de firmeza no estádio 1 foi 5 vezes maior que a do estádio 2 e 10 vezes maior que a do estádio 3 (Tabela 2).

A perda de firmeza é um processo decorrente principalmente da degradação da parede celular pelas enzimas pectinolíticas. Em goiabas 'Pedro Sato', Xisto (2002) observou que a atividade da enzima pectinametilesterase (PME) aumenta durante o armazenamento dos frutos, enquanto que a atividade da enzima poligalacturonase (PG) diminuiu. Carvalho (1994), também observou aumento da atividade da PME em goiabas 'Kumagai' armazenadas sob refrigeração discordando dos resultados obtidos por ElZoghbi (1994), que observou decréscimo da atividade da PME durante o amadurecimento em goiabas colhidas em diferentes estádios de maturação.

$\mathrm{O}$ amolecimento dos frutos é considerado o processo do amadurecimento mais sensível ao etileno. A síntese das enzimas que atuam na degradação da parede celular, principalmente PME e PG, parece, na maioria dos casos, ser dependente da ação do etileno (Lelièvre et al., 1997). Em pêras imaturas, Gerasopoulos \& Richardon (1996), verificaram que $0,1 \mu 1.1^{-1}$ de etileno foi capaz de induzir o amolecimento, porém não atuou em outros aspectos do amadurecimento. Esta elevada sensibilidade ao etileno que o processo de amolecimento apresenta, pode justificar a intensa perda de firmeza ocorrida nos primeiros dias após a colheita das goiabas 'Pedro Sato'. 

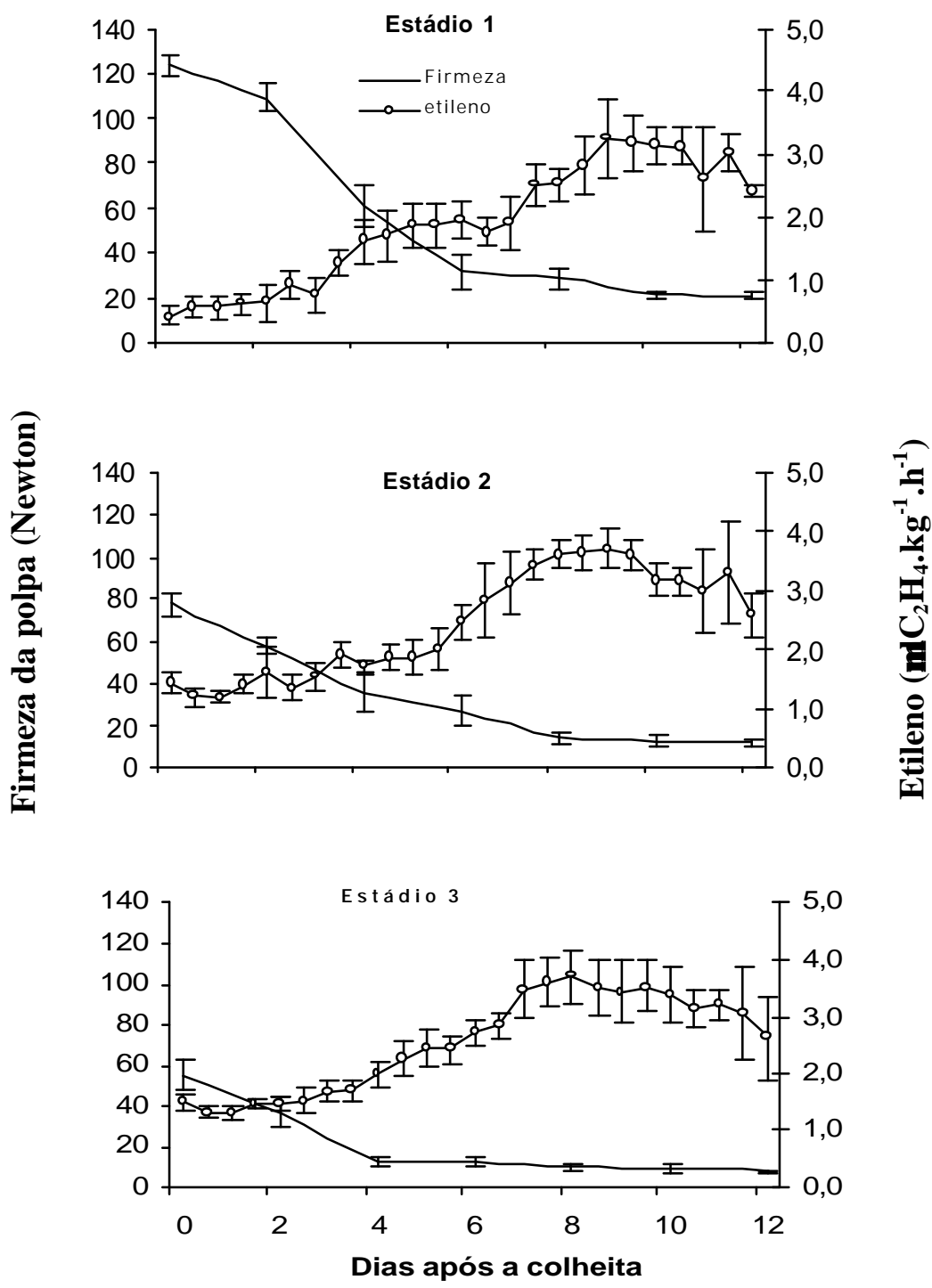

Figura 4- Produção de etileno e as transformações da firmeza em goiabas 'Pedro Sato' colhidas em diferentes estádios de maturação e armazenadas a $23 \pm 1{ }^{\circ} \mathrm{C}$ e 85 $\pm 5 \%$ UR. (Estádio de maturação 1, 2 e 3, frutos colhidos com cor da casca verde-escura, verde-clara e verde-amarela, respectivamente). 
Tabela 2. Influência dos estádios de maturação nas taxas de variação da cor da casca, cor da polpa e firmeza da polpa em função do tempo de armazenamento em goiabas 'Pedro Sato' armazenadas a $23{ }^{\circ} \mathrm{C}$ e $855 \%$ UR.

\begin{tabular}{|c|c|c|c|c|}
\hline \multirow[b]{2}{*}{ Variável } & \multirow[b]{2}{*}{ Dias após a colheita } & \multicolumn{3}{|c|}{ Estádios de maturação $^{1}$} \\
\hline & & Estádio 1 & Estádio 2 & Estádio 3 \\
\hline & & 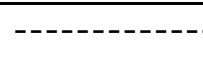 & ------ Tax: & -------------. \\
\hline \multirow[t]{8}{*}{ Cor da casca } & 1 & $-2,75$ & $-2,96$ & $-2,31$ \\
\hline & 2 & $-2,66$ & $-2,84$ & $-2,23$ \\
\hline & 4 & $-2,54$ & $-2,70$ & $-2,13$ \\
\hline & 6 & $-2,42$ & $-2,55$ & $-2,04$ \\
\hline & 8 & $-2,31$ & $-2,42$ & $-1,95$ \\
\hline & 10 & $-2,20$ & $-2,29$ & $-1,86$ \\
\hline & 12 & $-2,10$ & $-2,17$ & $-1,78$ \\
\hline & 14 & $-2,01$ & $-2,06$ & $-1,70$ \\
\hline \multirow[t]{8}{*}{ Cor da polpa } & 1 & 2,65 & 1,92 & 1,69 \\
\hline & 2 & 2,25 & 1,56 & 1,35 \\
\hline & 4 & 1,73 & 1,07 & 0,89 \\
\hline & 6 & 1,20 & 0,58 & 0,44 \\
\hline & 8 & 0,68 & 0,09 & $-0,02$ \\
\hline & 10 & 0,15 & $-0,40$ & $-0,48$ \\
\hline & 12 & $-0,37$ & $-0,89$ & $-0,94$ \\
\hline & 14 & $-0,90$ & $-1,38$ & $-1,39$ \\
\hline \multirow[t]{8}{*}{ Firmeza } & 1 & $-14,89$ & $-9,86$ & $-4,90$ \\
\hline & 2 & $-11,98$ & $-7,82$ & $-3,98$ \\
\hline & 4 & $-8,96$ & $-5,74$ & $-3,02$ \\
\hline & 6 & $-6,71$ & $-4,21$ & $-2,29$ \\
\hline & 8 & $-5,02$ & $-3,09$ & $-1,73$ \\
\hline & 10 & $-3,76$ & $-2,27$ & $-1,31$ \\
\hline & 12 & $-2,81$ & $-1,66$ & $-1,00$ \\
\hline & 14 & $-2,10$ & $-1,22$ & $-0,76$ \\
\hline
\end{tabular}

${ }^{\mathrm{T}}$ Estádio de maturação 1, 2 e 3, frutos colhidos com cor da casca verde-escura, verde clara e verde-amarela, respectivamente. 
Cor da polpa: O croma foi crescente para todos os estádios de amadurecimento até 10 dias após a colheita. Após este período observou-se uma diminuição na intensidade da coloração devida, provavelmente, à degradação dos pigmentos em função do elevado grau de senescência que se encontravam os frutos (Figura 5). Para esta variável, observou-se que o aumento da produção de etileno ocorreu juntamente com a mudança de coloração da polpa. A mudança da coloração apresentou taxas decrescentes ao longo do armazenamento, sendo semelhante entre os estádios (Tabela 2).

O licopeno é um dos principais pigmentos responsáveis pela coloração da polpa em goiabas do tipo vermelha (Cross, 1987). A biossíntese deste pigmento, segundo Oller et al. (1991), é fortemente dependente do etileno. Em tomates trangênicos com síntese de etileno reduzida, o processo da síntese de licopeno foi sensivelmente retardado (Klee, 1993). Parece que, em goiabas, a síntese de licopeno também é fortemente dependente do etileno, o que pode ser notado ao observar o comportamento semelhante entre a curva de produção de etileno e curva de mudança de coloração da polpa.

Sólidos solúveis totais (SST): O teor de SST apresentou um leve aumento no decorrer do amadurecimento em todos os estádios de maturação (Figura 6). Estes resultados estão de acordo com Pivetta et al. (1992), o que não verificaram mudanças no teor de sólidos solúveis em função do ponto de colheita. Jacomino (1999), trabalhando com goiabas 'Kumagai' submetidas a diferentes temperaturas de armazenamento, também observou discreto aumento nos valores de SST ao longo do armazenamento. Segundo Rhodes (1980), os frutos que não contêm açúcares de reserva, não apresentam mudanças significativas nos teores de açúcares e consequientemente no teor de sólidos solúveis totais, durante o amadurecimento. Isto pode explicar porque esta variável não apresentou diferenças significativas entre os estádios de maturação, visto que a goiaba não apresenta níveis elevados de açúcares de reserva.

Os açúcares, os quais representam a maior porcentagem dos sólidos solúveis, são consumidos durante o amadurecimento no processo respiratório. Entretanto, a degradação dos açúcares de reserva, como amido, e dos polímeros constituintes da parede celular promovem o aumento dos açúcares solúveis. O etileno tem papel 
fundamental neste processo, pois promove a síntese das enzimas que atuam na degradação dos polímeros da parede celular e dos carboidratos de reserva (Chitarra Chitarra, 1990).
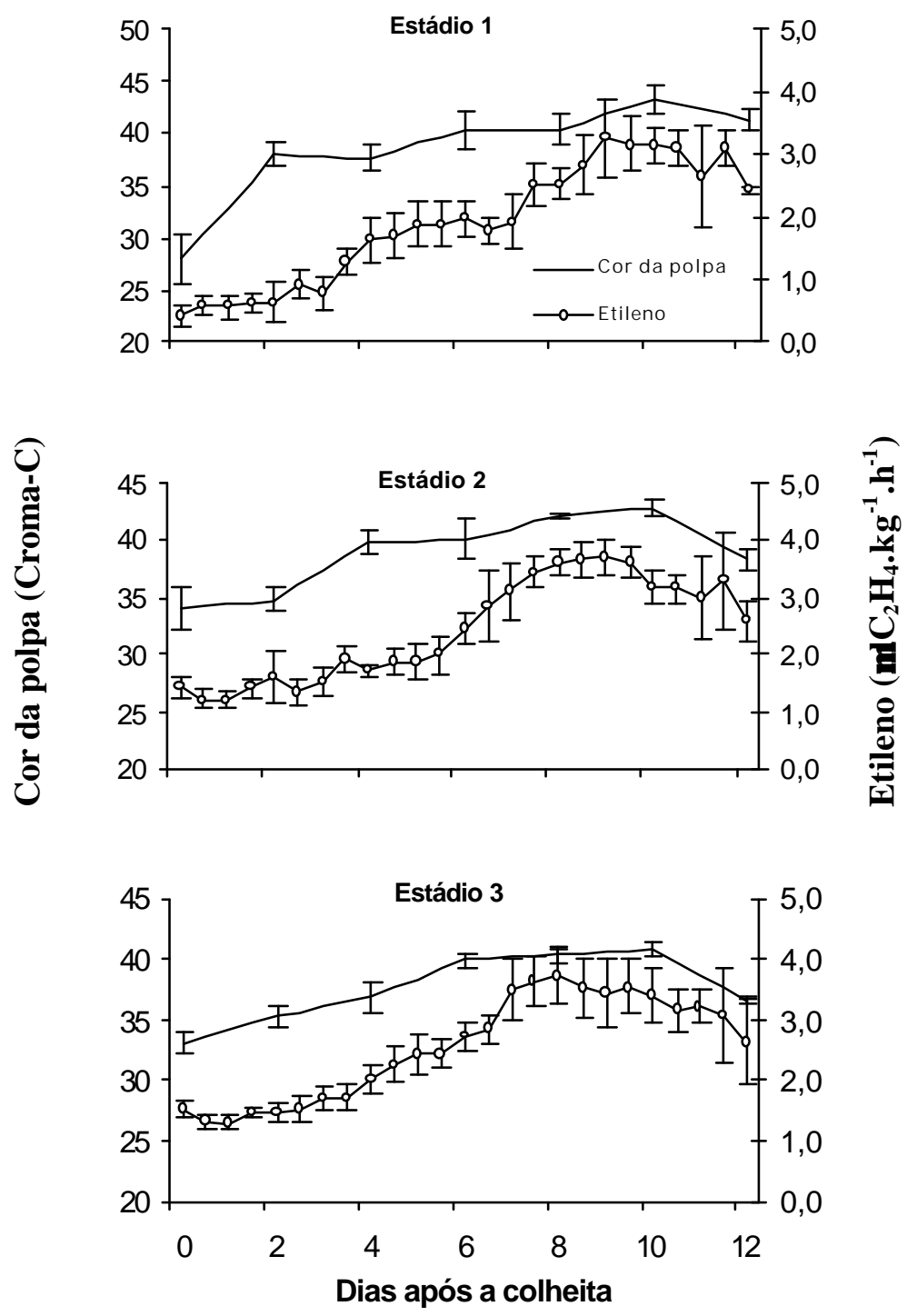

Figura 5- Produção de etileno e transformações na cor da polpa em goiabas 'Pedro Sato' colhidas em diferentes estádios de maturação armazenadas a $23 \pm 1{ }^{\circ} \mathrm{C}$ e $85 \pm$ $5 \%$ UR. (Estádio de maturação 1, 2 e 3, frutos colhidos com cor da casca verde-escura, verde-clara e verde-amarela, respectivamente). 
Em goiabas 'Pedro Sato', não foi observada forte relação entre a produção de etileno e o teor de SST (Figura 6). O discreto aumento no teor de SST antecedeu a máxima produção de etileno, em todos os estádios de maturação. Durante o período de máxima produção de etileno, também foi observada a máxima atividade respiratória, o que pode explicar a redução do teor de SST neste período.

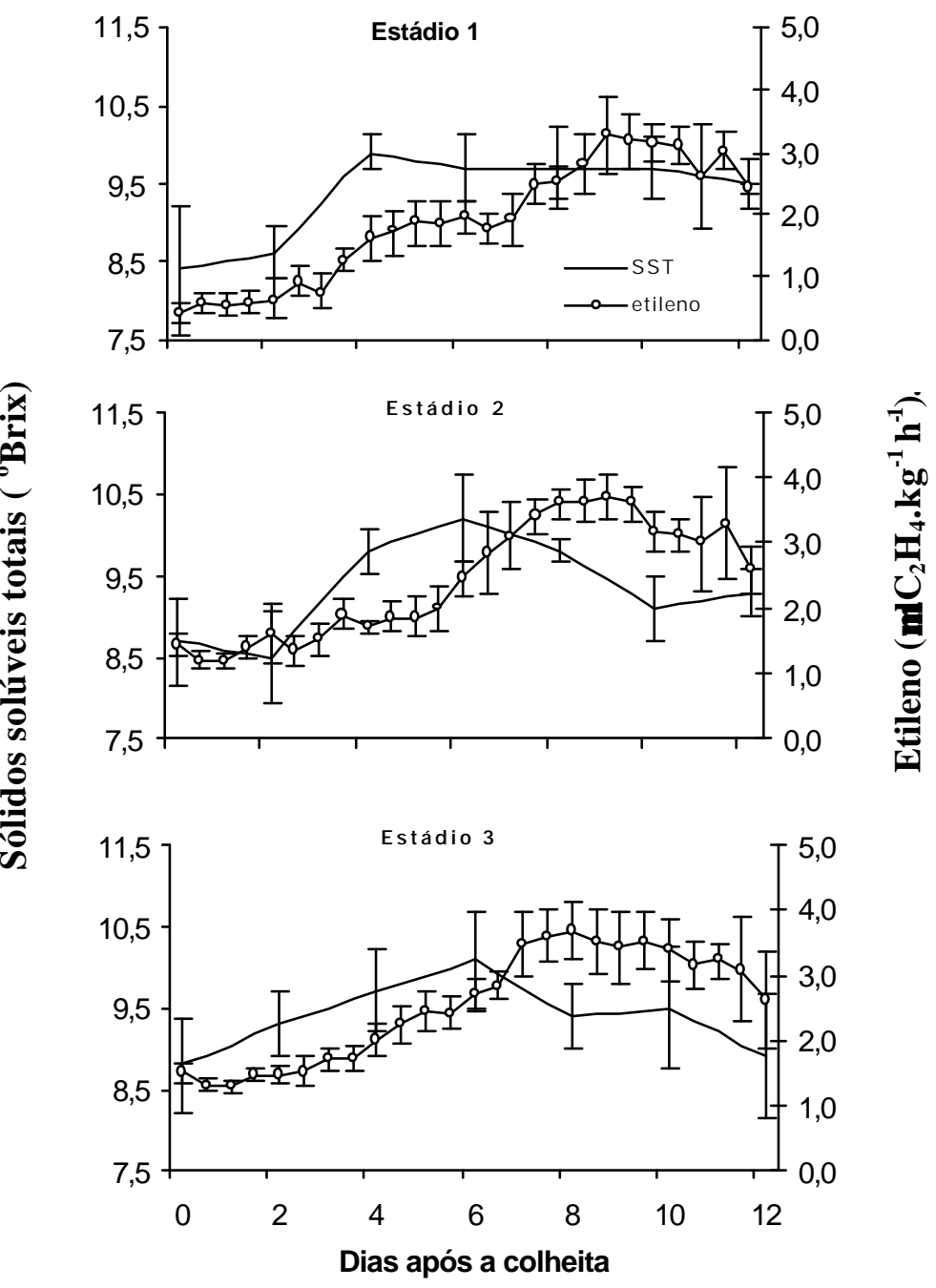

Figura 6- Produção de etileno e transformações no teor de sólidos solúveis totais (SST) em goiabas 'Pedro Sato' colhidas em diferentes estádios de maturação e armazenadas a $23 \pm 1{ }^{\circ} \mathrm{C}$ e $85 \pm 5 \%$ UR. (Estádio de maturação 1, 2 e 3, frutos colhidos com cor da casca verde-escura, verde-clara e verde-amarela, respectivamente) 
Acidez total titulável (ATT): Observou-se um pequeno aumento no teor de acidez com posterior diminuição (Figura 7). Dados semelhantes foram obtidos por Xisto (2002), em goiabas 'Pedro Sato’ tratadas ou não com cálcio e por Gianonni (2000), em goiabas 'Kumagai', sob refrigeração. Ambos observaram pequeno aumento do teor de acidez até quatro dias após o armazenamento.

Verificou-se uma tendência de diminuição do teor de acidez no período de máxima produção de etileno, período que corresponde também à máxima atividade respiratória (Figura 7). A diminuição nos teores de acidez durante o amadurecimento é um processo esperado, em função da oxidação dos ácidos orgânicos na respiração (Awad, 1993).

Teor de vitamina $\mathrm{C}$ : $\mathrm{O}$ teor de vitamina $\mathrm{C}$ tendeu a um aumento no início do armazenamento com posterior diminuição, sendo mais expressivo no estádio 3 (Figura 8).

O decréscimo do conteúdo de vitamina $\mathrm{C}$ pode indicar o início da senescência, pois segundo Esteves et al. (1984), o teor de vitamina C aumenta durante o amadurecimento e decresce rapidamente durante a senescência. $\mathrm{O}$ aumento do teor de vitamina C em goiabas 'Pedro Sato', durante o armazenamento, também foi observado por Mattiuz (2002). Segundo Mercado-Silva et al. (1998) e Teaotia et al. (1970) o aumento do teor de vitamina $\mathrm{C}$ pode ser resultado da produção de precursores do ácido ascórbico na respiração.

Os teores de vitamina C variaram de 33 a $60 \mathrm{mg}$ de ácido ascórbico.100g de polpa $^{-1}$. Estes resultados são inferiores aos obtidos por Xisto (2002) em goiabas 'Pedro Sato' que foram de 138,47 a $67,78 \mathrm{mg}$ ácido ascórbico.100g de polpa ${ }^{-1}$ e também aos obtidos por Ojeda (2001). Este fato pode ser atribuído à diferença entre os estádios de maturação e a época de cultivo, corroborando com Rathore, (1976).

$\mathrm{O}$ pequeno aumento observado no teor de vitamina $\mathrm{C}$ antecedeu a máxima produção de etileno em todos os estádios de maturação. Assim como para a acidez, o teor de vitamina $\mathrm{C}$, diminuiu no período de maior produção de etileno que correspondeu ao período de intensa atividade respiratória. 

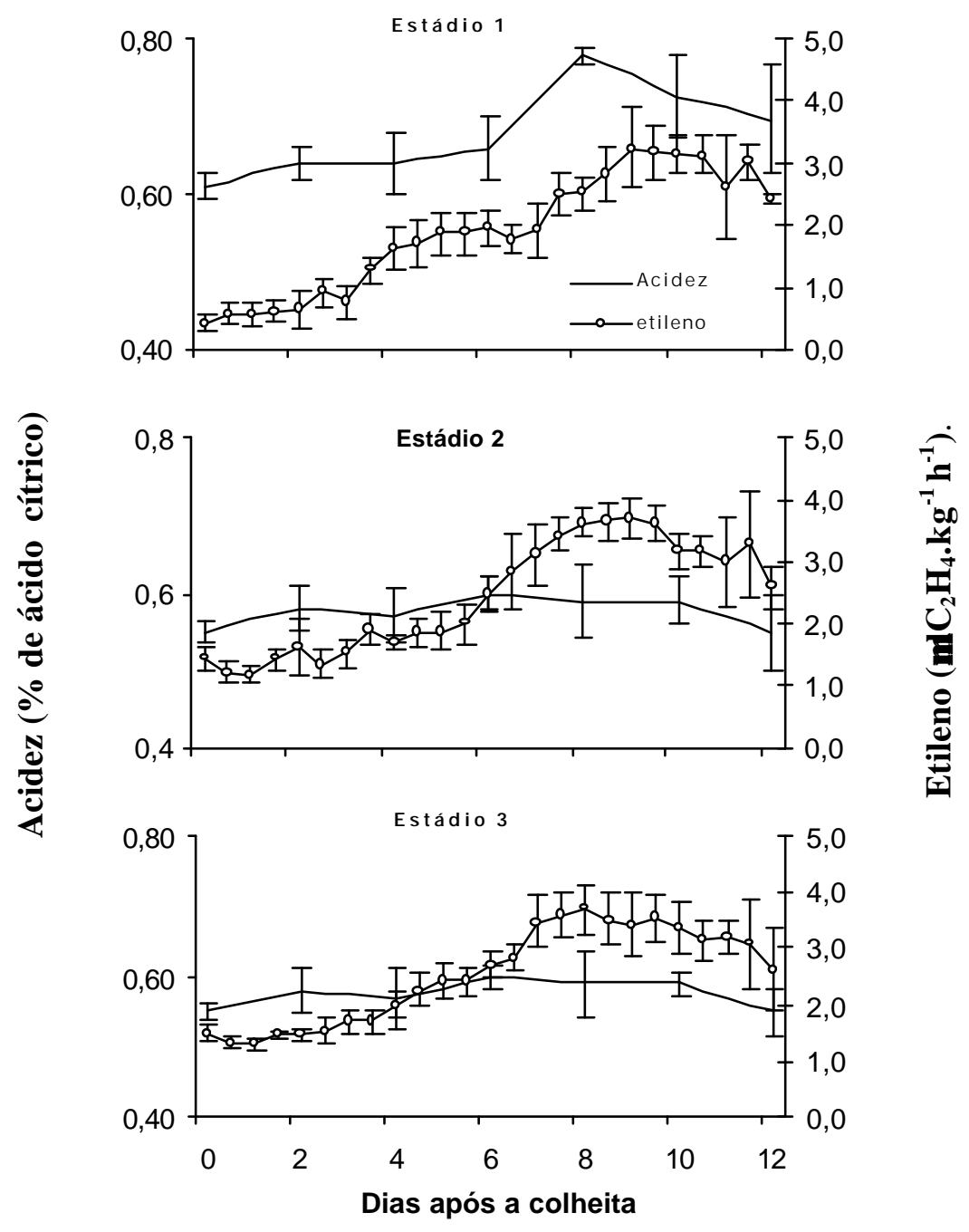

Figura 7- Produção de etileno e transformações no teor de acidez total titulável (ATT) em goiabas 'Pedro Sato' colhidas em diferentes estádios de maturação e armazenadas a $23 \pm 1{ }^{\circ} \mathrm{C}$ e $85 \pm 5 \%$ UR. (Estádio de maturação 1, 2 e 3, frutos colhidos com cor da casca verde-escura, verde-clara e verde-amarela, respectivamente). 


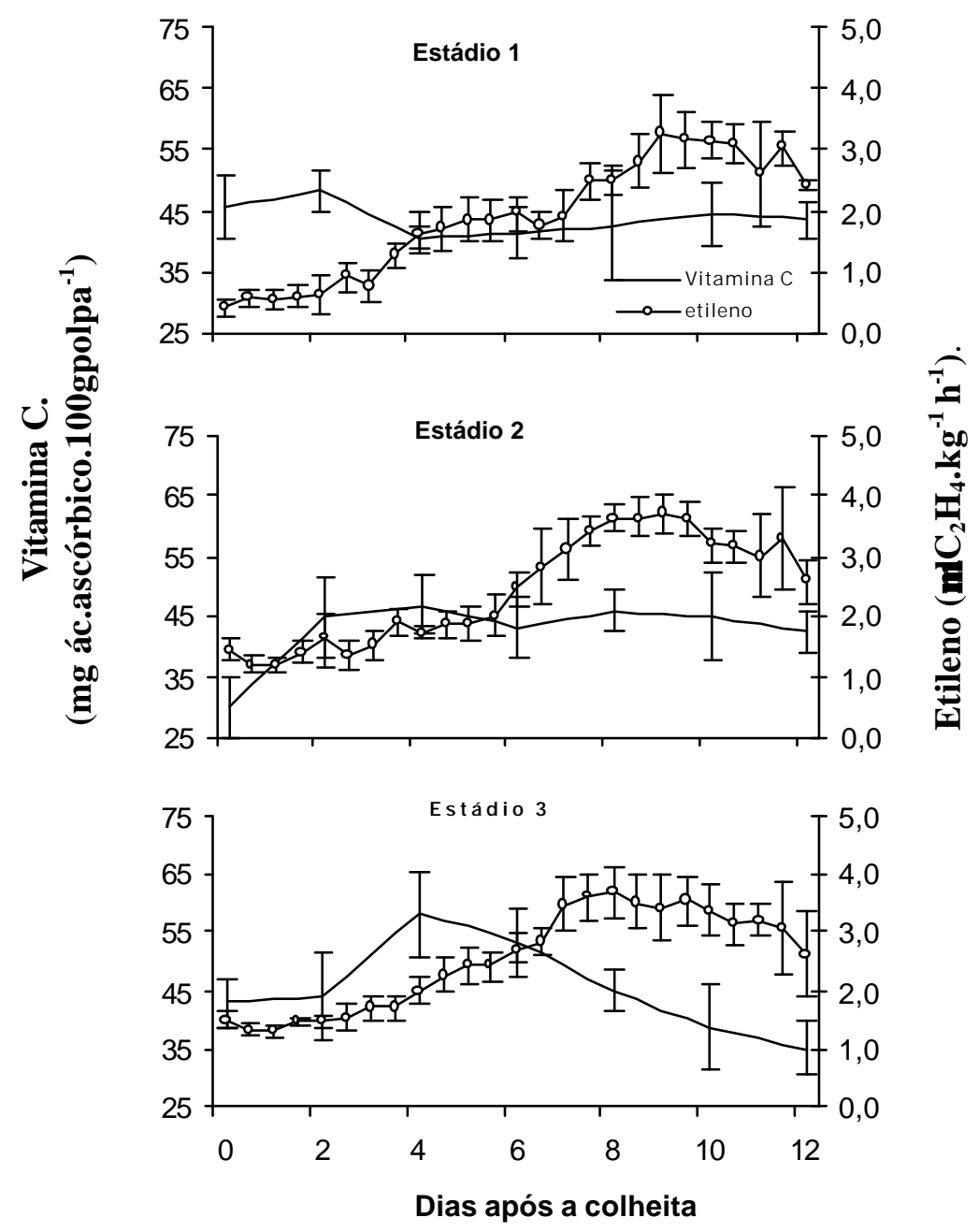

Figura 8- Produção de etileno e transformações no teor vitamina $\mathrm{C}$ em goiabas 'Pedro Sato' colhidas em diferentes estádios de maturação e armazenadas a $23 \pm 1{ }^{\circ} \mathrm{C}$ e $85 \pm 5 \%$ UR. (Estádio de maturação 1, 2 e 3, frutos colhidos com cor da casca verde-escura, verde-clara e verde-amarela, respectivamente).

Entende-se que o completo amadurecimento de um fruto ocorre quando o mesmo atinge a máxima qualidade comestível (Watada et al., 1984; Tucker, 1993 Wills et al., 1998; Lelivrièvre et al., 1997; Giovannoni, 2001). Com base neste conceito, o completo amadurecimento dos frutos colhidos nos estádios 3, 2 e 1 foi atingido aos dois, quatro e seis dias após a colheita, respectivamente. Após este período, os frutos apresentaram 
odor estranho, sabor desagradável e baixa firmeza. O aspecto de sobremaduro foi intensificado pela perda da coloração da casca e pelo aspecto gelatinoso da região placentária (Figura 9).

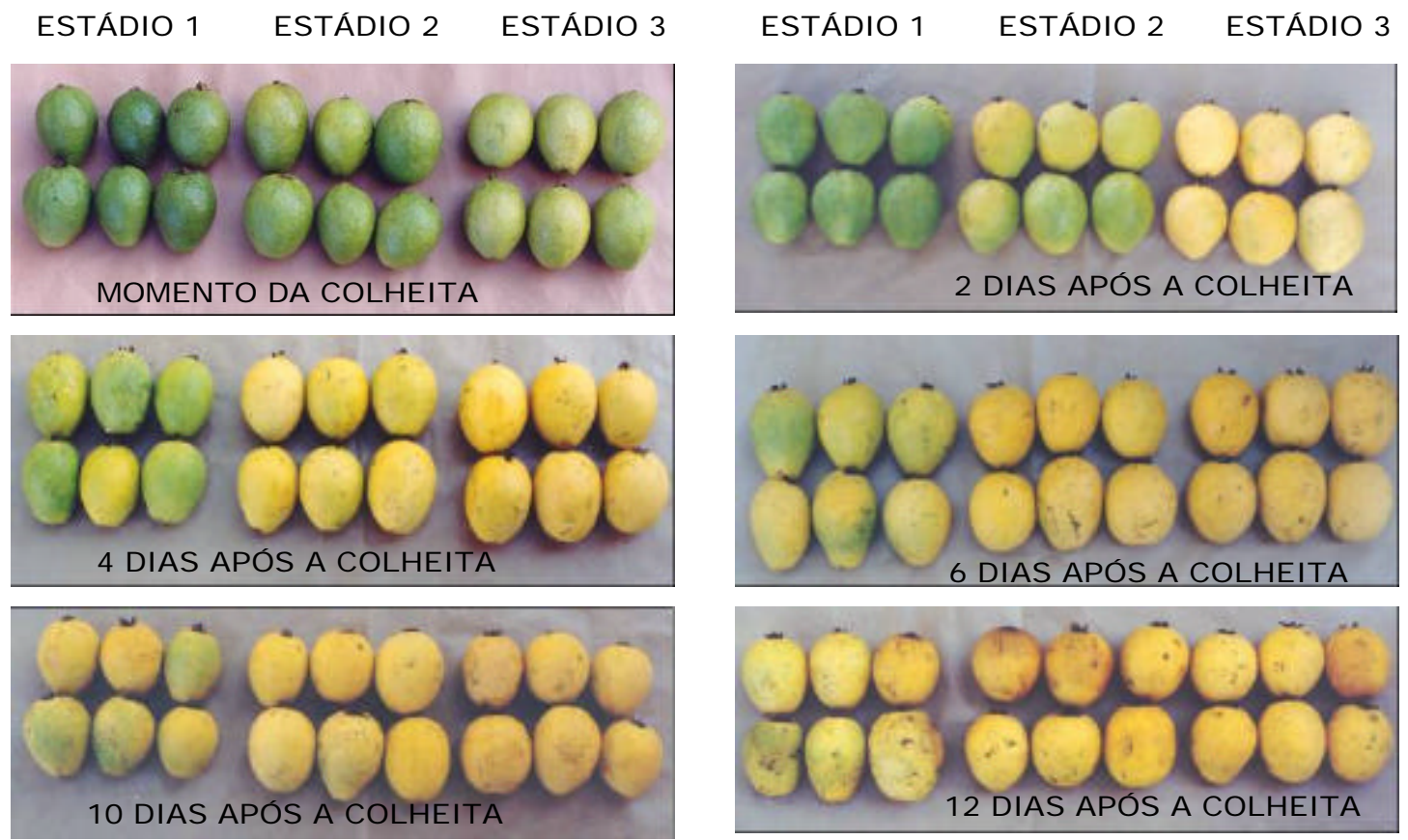

Figura 9- Goiabas 'Pedro Sato' colhidas em diferentes estádios de maturação e armazenadas a $23 \pm 1{ }^{\circ} \mathrm{C}$ e $85 \pm 5 \%$ UR. (Estádio de maturação 1, 2 e 3, frutos colhidos com cor da casca verde-escura, verde-clara e verde-amarela, respectivamente).

Não foi detectada presença de patógenos durante todo o período de análise. $\mathrm{O}$ aspecto escuro da casca observado nos frutos a partir de 8 dias após a colheita são decorrentes da senescência natural dos frutos.

$\mathrm{Na}$ maioria dos frutos climatéricos, o pico respiratório e da produção de etileno corresponde ao período de completo amadurecimento do fruto. Entretanto, verificou-se que, em goiabas 'Pedro Sato', o pico climatério ocorreu após o completo amadurecimento das goiabas. A máxima atividade respiratória e produção de etileno ocorreram quando os frutos apresentavam elevado grau de senescência, após o período 
considerado viável ao consumo. O pico da atividade respiratória e da produção de etileno, não correspondeu ao período de intensas transformações físico-químicas, independente dos estádios de maturação, conforme observado nas Figuras 1 a 8 . Possivelmente, estes processos do amadurecimento não necessitem do pico de etileno, mas sim, da presença do mesmo. O etileno por si só é um sinalizador do amadurecimento, sendo fisiologicamente ativo em concentrações de 0.1 $\mu 1.1^{-1}$ (Abeles, 1992).

Resultados semelhantes foram obtidos em maçãs 'Golden Delicious' e 'Fuji'. Nestes frutos, a redução na firmeza da polpa e o aumento dos teores de SST precederam o pico de produção de etileno (Argenta, 1993).

Em pêssego, 'Shiro' e 'Rubyred', a síntese de etileno continua após o amadurecimento, porém o nível de etileno produzido é baixo (Abdi et al.,1997).

Portanto, a classificação dos frutos em climatéricos e não-climatéricos é uma simplificação do processo de amadurecimento.

\subsubsection{Experimento II}

\subsubsection{Resposta à aplicação de etileno exógeno e ao 1-metilciclopropeno}

Atividade respiratória e produção de etileno: os frutos tratados com 1-MCP (1metilciclopropeno) apresentaram atividade respiratória e produção de etileno inferiores aos frutos não tratados e tratados com etileno. A atividade respiratória e a produção de etileno dos frutos tratados com etileno foram semelhantes aos do controle (Figura 10).

A atividade respiratória apresentou aumento gradual até treze dias após a colheita, independente do tratamento. Os frutos que receberam etileno apresentaram atividade respiratória levemente superior aos demais tratamentos até nove dias após a colheita. A atividade respiratória nos frutos tratados com 1-MCP foi aproximadamente $50 \%$ menor que o controle, até sete dias após a colheita. Apesar do 1-MCP ter 
promovido a redução da atividade respiratória, a máxima atividade ocorreu no mesmo período que nos demais tratamentos (Figura 10).
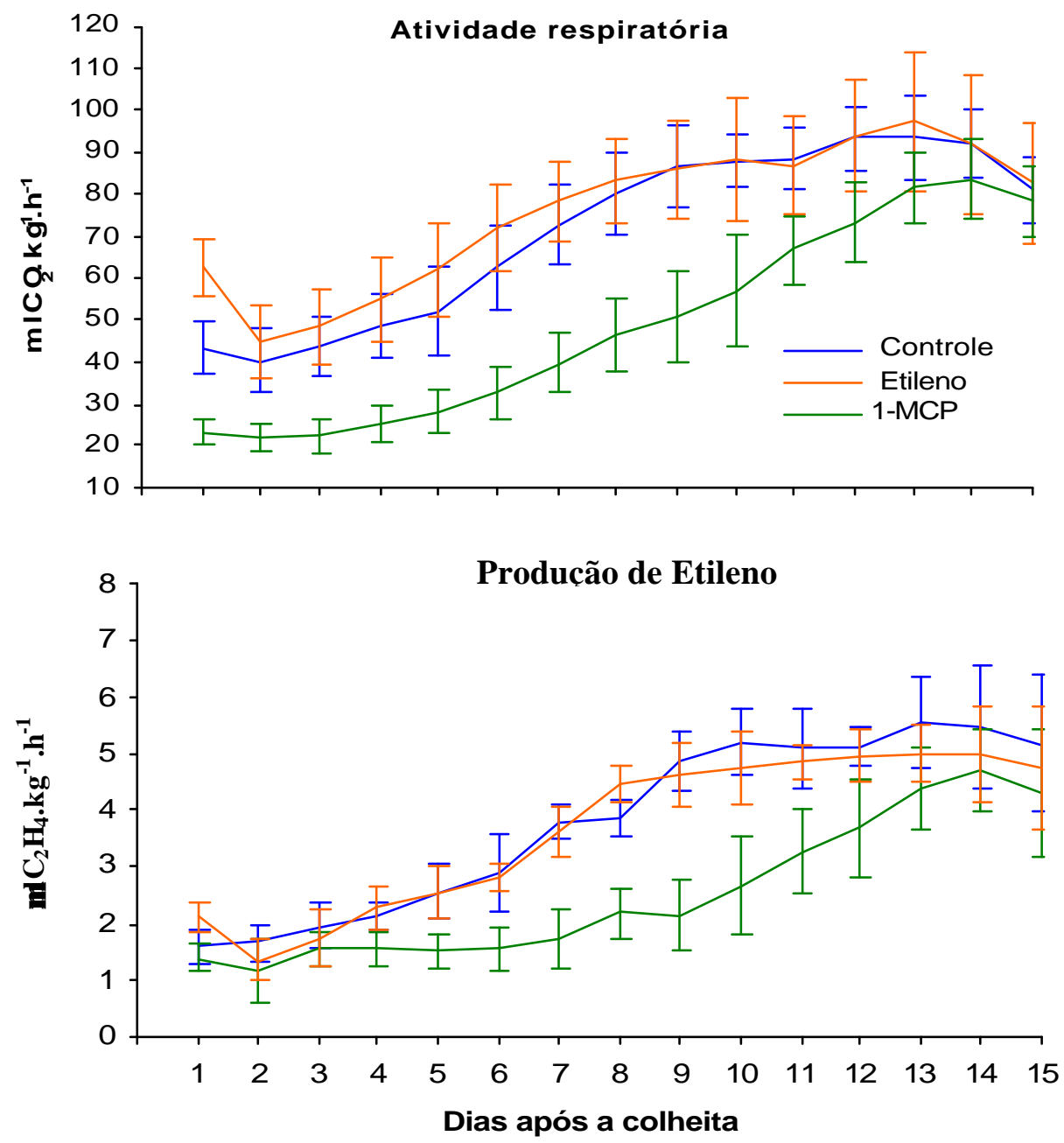

Figura 10- Atividade respiratória e produção de etileno de goiabas 'Pedro Sato'. Os frutos foram tratados com etileno (1000 $\mu 1 . .^{-1}$ durante 24 horas) ou 1-MCP (300nl. $1^{-1}$ durante 12 horas) e armazenados a $23^{\circ} \mathrm{C}$ e $85 \pm 5 \%$ UR. 
A aplicação de etileno não proporcionou aumento da produção de etileno e não promoveu a antecipação do pico respiratório como é esperado para frutos climátericos (Figura 10). O fato dos frutos não terem respondido ao etileno exógeno pode ter sido em função do estádio de maturação das goiabas. Segundo Chitarra \& Chitarra, (1990), dependendo do estádio de maturação, os frutos climatéricos já iniciaram a produção autocatalítica de etileno não respondendo a aplicação de etileno exógeno.

Reyes \& Paull (1995) observaram que frutos da variedade 'Beaumont' colhidos no estádio verde responderam à aplicação de etileno acelerando o processo de amadurecimento. Porém, os frutos colhidos no estádio 1/4 amarelo não responderam à aplicação de etileno exógeno independente do tempo de exposição (24 ou 48 horas).

Para os frutos que receberam 1-MCP a produção de etileno foi reduzida. As maiores diferenças foram observadas entre quatro e onze dias após a colheita.

A redução da atividade respiratória e da produção de etileno, promovida pelo 1MCP é resultado da inibição da ação do etileno promovida por este composto. O 1-MCP liga-se de modo irreversível aos receptores de etileno presente nas células, impedindo assim, a ligação do etileno (Silsler \& Serek, 1997). Desta forma, a ação do etileno é bloqueada afetando os processos do amadurecimento dependente de etileno. A própria produção autocatalítica é afetada, como foi sugerido por Golding (1998). Isto pode explicar a menor produção de etileno verificada no tratamento com 1-MCP.

$\mathrm{O}$ amadurecimento não é totalmente bloqueado na presença de 1-MCP devido possivelmente do aumento da produção novos de receptores durante o amadurecimento, que permite a contínua ação do etileno (Yen et al., 1995).

O 1-MCP tem se mostrado eficiente na contenção do processo de amadurecimento em outras frutas como, maçã, banana, tomate e mamão (Sisler et al., 1996; Fan et al., 1999; Macnish et al., 2000; Jacomino et al., 2002). 
Variáveis físico-químicas: os frutos tratados com 1-MCP apresentaram diferenças em relação ao controle para todas as variáveis analisadas. Enquanto que os frutos tratados com etileno apresentaram o mesmo comportamento que o controle. (Figura 11).

A cor da casca manteve-se verde até doze dias após a colheita nos frutos tratados com 1-MCP, enquanto que os frutos tratados com etileno e os frutos do controle encontravam-se totalmente amarelos, seis dias após a colheita (Figura 12). Isto demonstra que, para goiabas, a mudança de coloração da casca é um processo dependente de etileno. Possivelmente a menor ação do etileno promove a redução na síntese de carotenóides e diminui o processo de degradação da clorofila. 

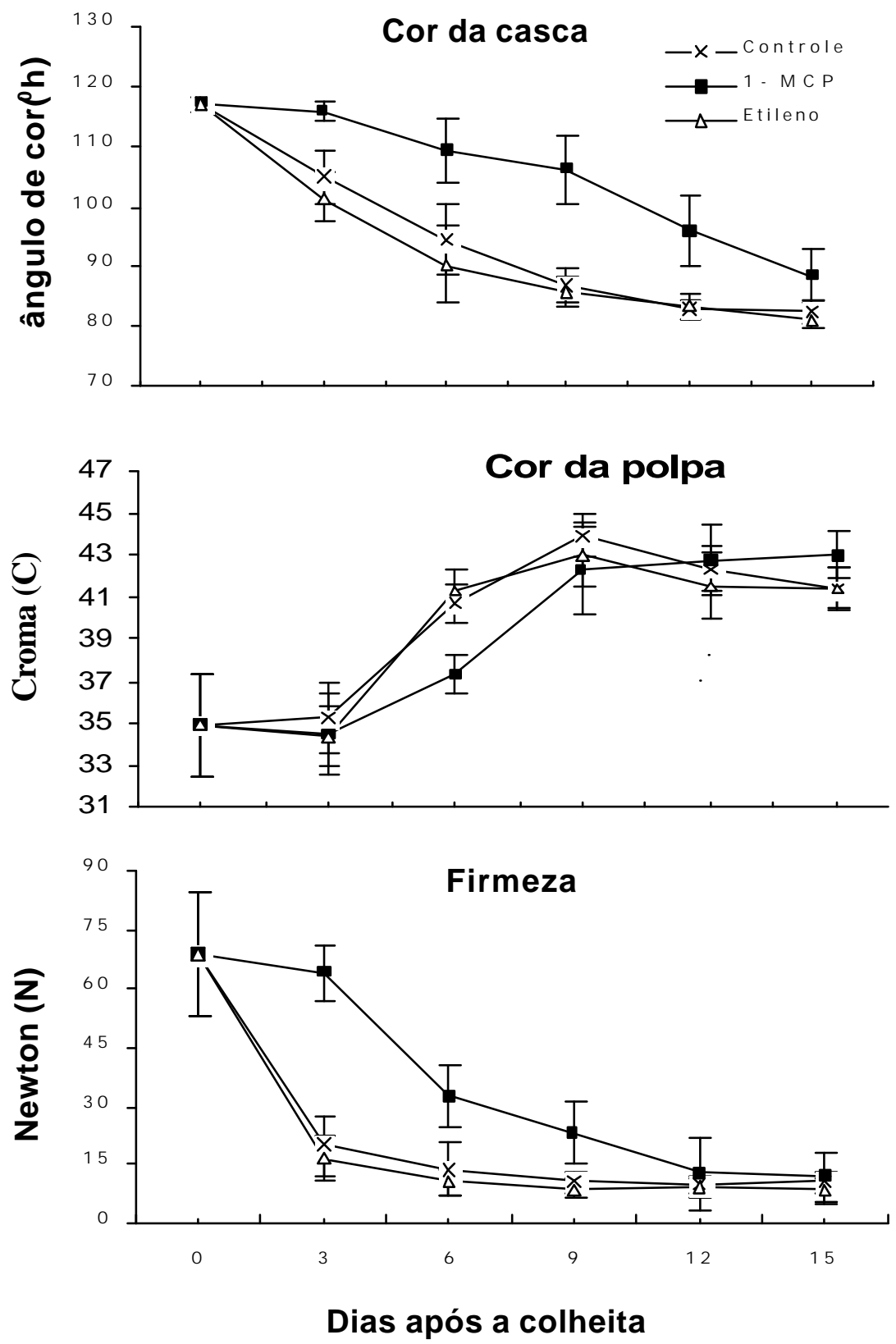

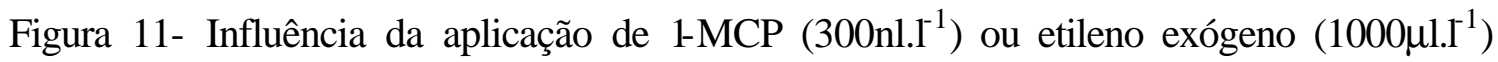
no amadurecimento de goiabas 'Pedro Sato', armazenadas a $23 \pm 1^{\circ} \mathrm{C}$ e $85 \pm$ $5 \%$ UR. 
A cor da polpa apresentou valores crescentes até nove dias após a colheita para os frutos dos tratamentos controle e etileno. Nos frutos tratados com 1-MCP, a cor da polpa foi menos intensa aos demais tratamentos até nove dias após a colheita (Figura 11). O etileno não promoveu o aumento no croma, indicando que não ocorreu maior biossíntese de pigmentos. A síntese de pigmentos, em especial o licopeno, responsável pela cor vermelha dos frutos, é fortemente reduzida na ausência de etileno (Klee, 1993; Murray et al., 1993). Entretanto, observou-se que, em goiabas, a aplicação de 1-MCP não promoveu uma drástica retenção da cor da polpa.

A perda de firmeza foi sensivelmente retardada com aplicação de 1-MCP (Figura 11). As maiores diferenças foram observadas entre três e seis dias após a colheita, período em que a firmeza das goiabas tratadas com 1-MCP foi aproximadamente três vezes maior que a firmeza obtida para as goiabas dos tratamentos controle e etileno. A redução da ação do etileno implica na menor ação das enzimas pectinolíticas, responsáveis pela degradação da parede celular e consequiente amolecimento dos frutos. Isto demostra que a perda de firmeza em goiabas é dependente da ação do etileno.

A aplicação do 1-MCP possibilitou esclarecer que o processo de amadurecimento em goiabas é dependente da ação do etileno. A habilidade do 1-MCP bloquear a ação do etileno promoveu também a menor produção deste fitohormônio, retardando o processo de amadurecimento. Isto foi verificado pela redução da atividade respiratória, menor perda da coloração da casca, maior manutenção da firmeza e retenção do desenvolvimento da cor da polpa.

Em goiabas tratadas com 1-MCP, parece haver a necessidade de maior biossíntese de etileno para que ocorra a mudança de coloração. As goiabas tratadas com este bloqueador só apresentaram coloração totalmente amarela doze dias após a colheita, neste período a produção de etileno foi de $3,68 \mu \mathrm{LC}_{2} \mathrm{H}_{4} \cdot \mathrm{kg}^{-1} \mathrm{~h}^{-1}$ As goiabas do controle e as tratadas com etileno apresentaram coloração totalmente amarela seis dias após a colheita, quando a produção de etileno foi de 2,88 e $2,82 \mu \mathrm{lC}_{2} \mathrm{H}_{4} \cdot \mathrm{kg}^{-1} \mathrm{~h}^{-1}$, respectivamente. $\mathrm{O}$ mesmo resultado foi observado para a cor da polpa e a firmeza da polpa. Os frutos tratados com etileno, ao contrário do esperado, desenvolveram o 
amadurecimento de maneira semelhante ao tratamento controle, possivelmente em função do estádio de maturação dos frutos.
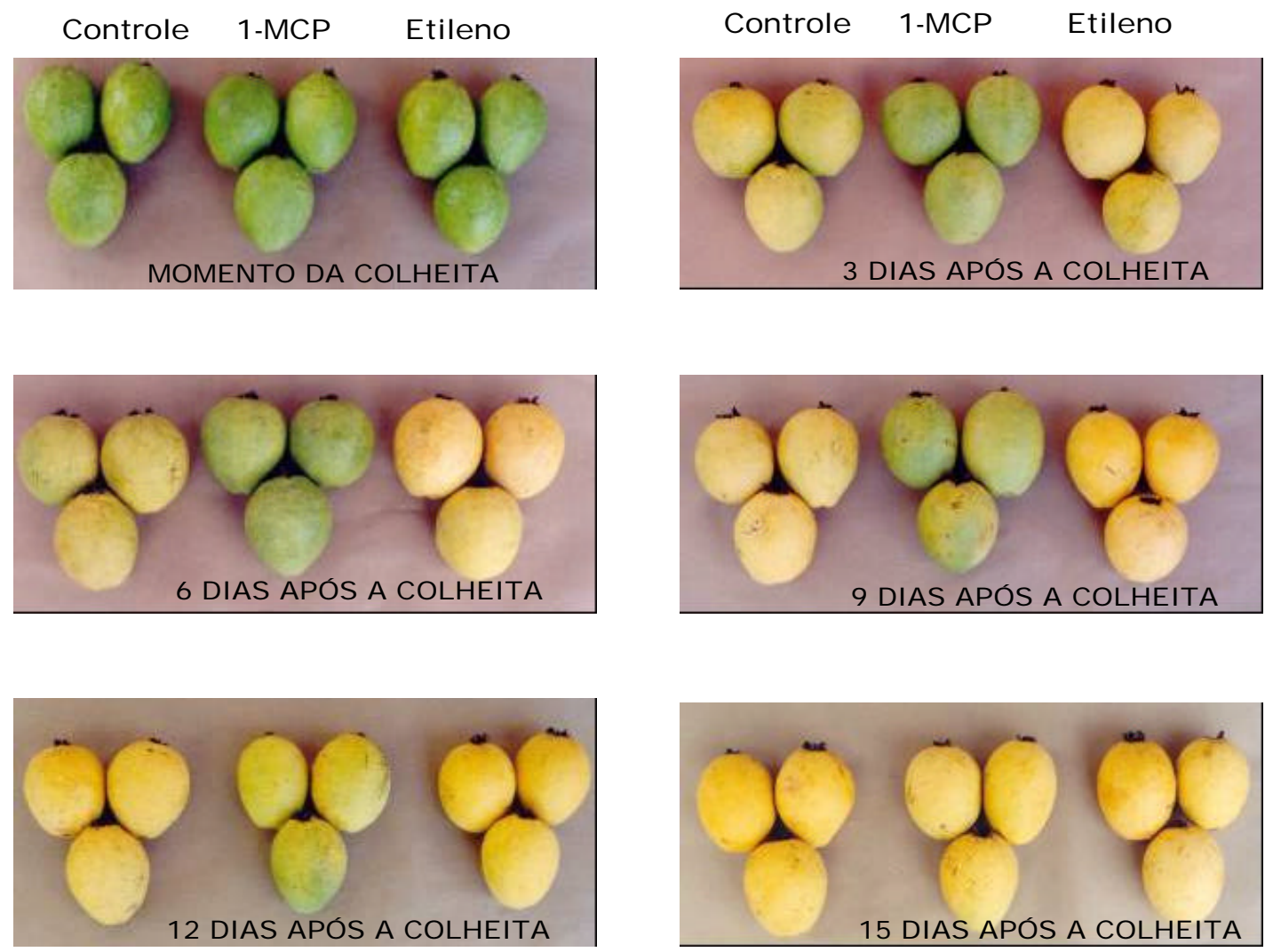

Figura 12- Influência da aplicação de etileno exógeno $\left(1000 \mu .1^{-1}\right)$ e 1-MCP $\left(300 \mu g .1^{-1}\right)$, no amadurecimento de goiabas 'Pedro Sato' armazenadas a $23 \pm 1{ }^{\circ} \mathrm{C}$ e $85 \pm$ $5 \%$ UR.

Apesar dos frutos tratados com etileno não terem apresentado uma antecipação do pico respiratório, a qual é uma característica de frutos climatéricos, a goiaba 'Pedro Sato' pode ser considerada climatérica. O aumento da respiração e da produção de etileno ocorreu em todos os tratamentos semelhante ao que ocorreu no experimento I, caracterizando o padrão climatérico. O aumento da produção de etileno controla o 
amadurecimento em goiabas conforme observado nos frutos tratados com 1-MCP. Porém, a máxima produção não corresponde à máxima qualidade comestível. Foi possível observar que a goiaba apresenta a capacidade de manter elevada a atividade respiratória e a produção de etileno durante determinado período da senescência. Desta forma, parece viável considerar que a goiaba 'Pedro Sato' apresenta uma variação do padrão climatérico de amadurecimento. 


\subsection{CONCLUSÃO}

Em função do material e da metodologia aplicada na realização deste trabalho, as seguintes conclusões podem ser feitas:

- Goiabas 'Pedro Sato' apresentam comportamento respiratório do tipo climatérico.

- O completo amadurecimento da fruta, caracterizado pela máxima qualidade comestível, antecedeu o pico climatérico.

- Independente do estádio de maturação no momento da colheita, os frutos apresentaram aumento da atividade respiratória e da produção de etileno durante a pós-colheita. 


\section{CONSIDERAÇÃO FINAL}

O processo de amadurecimento em goiabas 'Pedro Sato' apresenta inúmeras variações, demonstrando a importância do estudo detalhado da fisiologia para cada variedade. Estudos da atividade das enzimas relacionadas a biossíntese de etileno e da ultra-estrutura celular poderiam auxiliar no entendimento dos processos fisiológicos do amadurecimento em goiabas.

Os resultados obtidos neste trabalho demonstram que $\mathrm{o}$ processo de amadurecimento em goiabas é desencadeado mesmo na presença de pouco etileno e que a atividade respiratória é elevada deste o início do processo. Desta forma, o controle eficiente do amadurecimento só será possível com a redução imediata após a colheita, da atividade respiratória e da produção ou ação do etileno. 


\section{REFERÊNCIAS BIBLIOGRÁFICAS}

ABDI, N.; HOLFORD, P.; McGLASSON, W.B.; MIZRAHI, Y. Ripening behaviour and responses to proprylene in four cultivares of Japanese type plums. Postharvest Biology and Technology, v. 12, p. 21-34, 1997.

ABDI, N.; McGlASSON, W.B.; HOLFORD, P.; WILlIAMS, M.; MIZRAHI, Y. Responses of climateric and supressed-climacteric plums to treatment with propylene and 1- methylcyclopropene. Postharvest Biology and Technology, v.14, p.29-39, 1998.

ABEleS, F.B.; MORGAN, P.W.; SALTVEIT, M.E. Ethylene in Plant Biology. San Diego: Academic Press, 1992, 414p.

ADSULE, R.N.; KADAM,S.S. Guava. In: SALUNKHE, D.K.; KADAM, S.S. (Ed.). Handbook of fruit science and technology, production composition, storage and processing. New York: Marcel Dekker, 1995. cap. 9, p.419-433.

AKAMINE, E.K.; GOO, T. Repiration and ethylene production in fruits of species and cultivars of Psidium and species of Eugenia. Journal of the American Society for Horticultural Science, v.104, n.5, p.632-635, 1979.

ALI, Z.M.; LAZAN,H. Guava. In: MITRA, S.K. Postharvest of physiology and storage of tropical and subtropical fruits. Wallingford: CAB intrnacional, 1997. cap.6, p. 145-165. 
ARGENTA, L.C. Concentração de etileno interno e maturação de maçãs cvs. Gala, Golden Delicious e Fuji. Revista Brasileira de Fruticultura, v.15, n.1, p.125-132, 1993.

ASKAR, A.; EL-NEMR, S.E.; BASSIONNY, S.S. Aroma constituents in white and pink guava fruits. Alimenta, v.25, p.162-167, 1986.

ATTA-ALY, M.A.; BRECHT, J.K.; HUBER, D.J. Ripening tomato locule gel tissue in response to ethylene. Postharvest Biology and Technology, v.19, n.3, p. 239-244, 2000.

AWAD, M. Fisiologia pós-colheita de frutos. São Paulo: Nobel, 1993. 114p.

BEM-YEHOSHUA, S. Individual seal-packaging of fruit and vegetables in plastic filma new postharvest technique. HortScience, v.20, n.1, p. 32-37, 1985.

BIALE, J.B. The postharvest biochemestry of tropical and subtropical fruits. Advances in Food Research, v.10, p.293-354, 1960.

BIALE, J. B.; BARCUS, D. E. Respiratory patterns in tropical fruits of the amazon Basin. Tropical Science, v.12, p.93-104, 1970.

BLEINROTH, E. W. Colheita e beneficiamento. In: GONCATTI NETO, A.; GARCIA, A.E.; ARDITO, E.F.G.; GARCIA, E.E.C.; BLEINROTH, E.W.; MATALIO, M.; CHITARRA, M.I.F.; BORIN, M. R. Goiaba para exportação: procedimentos de colheita e pós-colheita. Brasília: EMBRAPA, 1996 cap.2, p.12-23. (Série Publicações Técnicas FRUPEX, 20). 
BOTELHO, R.V. Efeito do tratamento pós-colheita com cálcio na ocorrência de antracnose (Colletotrichum gloeosporioides Penz) e no amadurecimento de goiabas (Psidium guajava L.) Botucatu, 1996. 122p. Dissertação (Mestrado)- Faculdade de Ciências Agronômicas, Universidade Estadual Paulista "Julio de Mesquita filho".

BRODY, A.L. Envasado de alimentos en atmosferas controladas, modificadas y vacio. Zaragoza: Acribia, 1996. 220p.

BROWN, B.I.; WILLS, R.B.H. Post-harvest changes in guava fruit of different maturing. Scientia Horticulturae, v.19, n.3/4, p.237-243, 1983.

CARVALHO, C.R.L.; MANTOVANI, D.M.B.; CARVALHO, P.R.N.; MORAES, R.M.M. Análises químicas de alimentos. Campinas: ITAL, 1990. 121p.

CARVALHO, H.A. de. Utilização de atmosfera modificada na conservação pós-colheita da goiaba 'Kumagai'. Lavras, 1999. 155p. Tese (Doutorado) Faculdade de Ciências dos Alimentos, Universidade Federal de Lavras.

CASTRO, J.V. SIGRIST, J.M.M: Matéria-prima. In: MEDINA, J.C.; CASTRO, J.V.; SIGRIST, J.M.M; MARTIN, Z.; KATO, K.; MAIA, M.L.; GARCIA, A.E.B.; LEITE, R.S.S.F. Goiaba: cultura, matéria- prima, processamento e aspectos econômicos. 2. ed. Campinas: ITAL, 1988. cap.2, p. 121-140. (Série Frutas tropicais, 6).

CHAN JÚNIOR, H.T.; KWOK, S.C.M. Identification and determination of sugars in some tropical fruit products. Journal of food Science, v.40, n.2 p. 419-420, 1976. 
CHITARRA, M.I.F. Características das frutas de exportação. In; GONGATTI NETO, A.; GARCIA, A. E.; ARDITO, E. F.G.; GARCIA, E.E.C.; BLEINROTH, E.W.; MATALLO, M.; CHITARRA, M.M.I.F.; BORDIN, M. R. Goiaba para exportação: procedimentos de colheita e pós-colheita. Brasília; EMBRAPA, 1996. cap.1, p.911. (Série Publicações Técnicas FRUPEX, 20).

CHITARRA, M.I.F.; CHITARRA, A.B. Pós-colheita de frutos e hortaliças: fisiologia e manuseio. Lavras: ESAL; FAEPE, 1990. 320p.

CHITARRA, M.I.F.: CHITARRA, A.B. CARVALHO, V.D. Algumas características dos frutos de duas cultivares de goiabeira (Pisidium guajava L ) em fase de maturação. In: CONGRESSO BRASILEIRO DE FRUTICULTURA, 6.; Recife, 1981, Anais. Recife: SBF, 1981. v.2, p.771-780.

CHOUDHURY, M.M.; COSTA, T.SILVA da.; ARAÚJO, J. L. P. Goiaba: Pós-colheita. Brasília: EMBRAPA, 2001, 45p. (Série Frutas do Brasil).

CLYDESDAL, F.M. Color as a factor in food choice. Critical Reviews in Food Science and Nutrition, v.33, n.1, p.83-101, 1993.

CROSS, J. Pigments in fruits. London: Academic Press, 1987, 303p.

DHILLON, B.S.; SINGH, S.N.; KUNDAL, G.S.; MINHAS, P.P.S. Studies on the developmental physiology of guava fruti (Psidium guajava L.) II. Biochemical characters. Punjab Horticultural Journal, v.27, n.3/4, p.212-221, 1987. 
DHINGRA, M.K.; GUPTA, O.P.; CHUNDAWAT, B.S. Studies on pectin yield ad quality of some guava cultivares in relation to cropping season and fruit maturity. Journal of Food Science and technology, v.20, n. 1/2, p.10-13, 1983.

DOWNS, C.G.; BRADY, C.J.; CAMPBELL, J.; McGLASSOM, W.B. Normal ripening cultivars of Pyrus serotina are either climateric or non- climateric. Science Horticulturae, v.4, p.125-130, 1991.

EL-BULK, R.E.; BABIKER, EL F.E.; EL TINAY, A.H. Changes in chemical composition of fruits during development and ripening. Food chemistry, v. 59 n.3, p.395-399, 1997.

EL- ZOGHIBI, M. Biochemical changes in some tropical fruits during ripening. Food Chemistry, v. 59, n.3, p. 395-399, 1994.

ESTEVES, M.T. da C.; CARVALHO, V. D. de. Modificações nos teores de amido, açúcares e grau de doçura de frutos de seis cultivares de goiabeira (Psidium guajava L.) em diferentes estádios de maturação. Ciência e Prática, v. 6, n.2, p.208-218, 1982.

ESTEVES, M.T. da C.; CARVALHO, V.D. de.; CHITARRA, M.I.F.; CHITARRA, A.B.; PAULA, M.B de. Caracterização dos frutos de seis cultivares de goiabeiras (Pisidium guajava L.) na maturação. I -Determinações físicas e químicas. In: CONGRESSO BRASILEIRO DE FRUTICULTURA, 7., Florianópolis, SC. 1983, Anais Florianópolis SC: SBF, 1984, v.2, p.477-489. 
FAN, X.; BLANKENSHIP, S.M.; MATTHEIS, J.P. 1-methylcyclopropene inhibits apple ripening. Journal of the American Society for Horticultural Science, v. 124, p.690-695, 1999.

FAO. Food and nutition division. <http://www.fao.org/es/dept/es960003.htm>.(15 set. 2001).

FERRARESE, L.; TRAINOTTI,L.; MORETTO, P. POLVERINO de LAURETO, P.; RASCIO, N.; CASADORO, G. Differential ethylene-inducible expression of cellulase in pepper plants. Plant Molecular Biologycal, v. 29, p. 735-747, 1995.

FLUHR, R., MATTOO, A.K. Ethylene-Biosynthesis and Perception. Critical reviews in Plant Sciences, v.15, n.5/ 6, p. 479-523, 1996.

FNP CONSULTORIA \& COMÉRCIO. Agrianual 2002: anuário estatístico da agricultura brasileira. São Paulo, 2002. 521p.

FRATESCHI, P.W.B. Radiação gama com ${ }^{60}$ cobalto na conservação pós-colheita de goiaba branca. Goiânia, 1999. 141p. Dissertação (Mestrado)- Escola de Agronomia, Universidade Federal de Goiás.

GERASOPOULOS, D.; RICHARDSON, D.G. Effects of exogenous propylene and fruit calcium on ripening of non-chilled and chilled Anjou pears. Postharvest Biology and Technology, v.8, p.111-120, 1996.

GERHARDT, L.B.A.; MANICA,I.; KIST, H.; SIELER, R.L. Características físicoquímicas dos frutos de quatro cultivares e três clones de goiabeira em Porto Lucena, RS. Pesquisa agropecuária brasileira, v.32, n.2, p.185-192, 1997. 
GIANONNI, J. A. Efeito da radiação gama e do cálcio na conservação pós-colheita da goiaba branca armazenada sob refrigeração. Botucatu, 2000. 181p. Dissertação (Mestrado)- Universidade Estadual Paulista "Júlio de Mesquita Filho".

GIOVANNONI, J. Molecular biology of fruit maturation and ripening. Annual Review Plant Physiology Plant Molecular Biology, v.52, p.725-749, 2001.

GOLDING, J.B.; SHEARER, D.; WYLLIE, S.G.; McGLASSON, W.B. Application of 1-MCP and propylene to identify ethylene-dependent ripening processes in mature banana fruit. Postharvest Biology an Technology , v.14, p. 87-98, 1998.

GOLDSCHMIDT, E.E. Ripening of citrus and other non-climateric fruits: A role for ethylene. Acta Horticultural, v. 463, p. 335-340, 1997.

GOLDSCHMIDT, E.E.; HURBEMEN, M.; GOREN, R. Probing the roles of endogenous ethylene in the degreening of citurs with ethylene antagonists. Plant Growth Regulation, v.12, p.325-329, 1993.

GRIERSON, D. Senescence in Fruits. HortiScience, v.22, n. 5, p.859-862, 1987.

GUTIERREZ, A.de S.; WATANABE, H.; SCHMIDT, M.dos R. A goiaba em números, Frutas e Legumes, n.14, mai-jun, 2002.

HARPSTER, M.H.; LEE, K. L.; DUNSMUIR, P. Isolation and characteriztion of a gene encoding endo- $\beta$-1,4-glucanase from pepper (Capsicum annuum L.). Plant Molecular Biologycal, v. 33, p. 47-59, 1997.

HUBER, D. J. The role of cell-wall hydrolysis in fruit softening. In: Horticultural Review. Wetsport, CT: AVI, 1983, p.619. 
IEA. Instituto de Economia Agrícola. Valor da produção <www.iea.sp.gov> Valor da produção (15 out. 2002).

JACOMINO, A.P. Conservação de goiabas 'Kumagai' em diferentes temperaturas e materiais de embalagem. Piracicaba, 1999. 90p. Tese (Doutorado)- Escola Superior de Agronomia “Luiz de Queiroz”, Universidade Estadual de São Paulo.

JACOMINO, A.P.; KLUGE, R.A.; BRACKMANN, A.; CASTRO, P. R. de C. Amadurecimento e senescêcnia de mamão com 1-metilciclopropeno. Scientia Agricola, v.59, n.2, p.303-308, 2002.

JAIN, N.; DHAWAN, K.; MALHOTRA,S.P.; SIDDIQUI, S.; SINGH, R. Compositional and enzymatic changes in guava (Psidium guajava L.) fruits during ripening. Acta Physiologiae Plantarum, v.23, n.3, p.357-362, 2001.

JOHN, P. Ethylene biosynthesis: The role of 1-aminocyclopropane-1-carboxylate (ACC) oxidase, and its possible evolutionary origin. Physiology Plantarumm, v.100, p.583-592, 1997.

KADER, A.A. Biochemical and physiological basis for effects of controlled and modified atmospheres on fruits and vegetables. Food Technology, v. 40, n.5, p.102-104, 1986.

KANELLIS, A. K.; SOLOMOS, T.; ROUBELAKS-ANGELAKIS, K.A. Supression of cellulase and poligalacutornase and induction of alcohol deydrogenase isoenzymes in avocado fruit mesocarp subjected to low oxygen stress. Plant Physiology, v. 96, p.269-274, 1991. 
KAVATI, R. Cultivares. In: SIMPÓSIO BRASILERIO SOBRE A CULTURA DA GOIABEIRA, 1., Jaboticabal, 1997. Anais. Jaboticabal: FCAV/UNESP-FUNEPGOIABRÁS, 1997, p. 1-16.

KIM, W.T.; YANG, S.F. Turnover of 1-aminocyclopropane-1-carboxylic acid synthase protein in wounded tomato fruit tissue. Plant Physiology, v. 100, p.1126-1131, 1992.

KLEE, H.J. Ripening physiology of fruit from trangenic tomato (Lycopersicon esculentum) plants with reduced ethylene synthesis. Plant Physiology. v.102, p.911-916, 1993.

KLUGE, R. A.; NACHTIGAL, J.C.; BILHALVA, A.B. Fisiologia e manejo póscolheita de frutas de clima temperado. 2. ed. Pelotas: UFPEL, 2002, 163p.

KNEE, M.: Evaluanting the pratical significance of ethylene in fruit storage. In: ROBERTS, J.A.; TUCKER, G.A. Ethylene and Plant Development. London: Butterworths, 1985. p.297-315.

LELIEVRE J.M.; LATCHE, A.; JONES, B.; BOUZAYEN, M. PECH J.C. Ethylene and fruit ripening. Physiology Plantarum, v. 101, p.727-739, 1997.

LIMA, M.A.; DURIGAN, J, F. Conservação de goiabas 'Pedro Sato' associando-se refrigeração com diferentes embalagens. Revista Brasileira de fruticultura, v.22, n.2, p. 232-236, 2000. 
LIMA, M.A.; DURIGAN, J.F.; TOSTES, D.R.D. Avaliação do comportamento respiratório de goiabas 'Pedro Sato' e a influência de diferentes embalagens na sua conservação sob refrigeração. In: CONGRESSO BRASILEIRO DE CIÊNCIA E TECNOLOGIA DE AlimENTOS, 16., Rio de Janeiro, 1998. Anais. Rio de Janeiro: SBCTA, p. 1980-1983, v.3. 1998.

MANICA, I.; ICUMA, I.M.; JUNQUEIRA, N.T.V.; SALVADOR, J.O.; MOREIRA, A.; MALAVOLTA, E. Fruticultura Tropical Porto Alegre: Cinco continentes, 2000. cap.6. 373p: Goiaba

MANNING, K. Soft fruit. In: SEYMOUR, G. B.; TAYLOR, J.E.; TUCKER, G..A Biochemestry of fruit ripening. London: Chapman \& Hall, 1993. p. 347-377.

MATTIUZ , B. Fisiologia e qualidade pós colheita de goiabas. Jaboticabal, 2002. 118p. Tese (Doutorado) - Faculdade de Ciências Agrárias e Veterinárias, Universidade Estadual Paulista "Júlio de Mesquita Filho".

MATTOO, A. K.; SUTTLE, J.C. The plant hormone ethylene. Florida: CRC Press, 1991. 337p.

McGLASSON, W.B. Ethylene and fruit ripening. HortScience, v.20, n.1, p. 51-54, 1985.

McMURCHIE, E.J.; McGLASSON, W.B.; EAKS, I.L. Treatment of fruit with propylene gives information about the biogenesis of ethylene. Nature, v. 273, p.235-236, 1972. 
MEDINA, J.C.;CASTRO, J.V. de.; SIGRIST, J.M.M.; DE MARTIN, Z,J.; KATO, K.; MAIA, M.L.; GARCIA, A.E.B.; FERNANDES, R.S.S. Goiaba: cultura, matériaprima, processamento e aspectos econômicos. 2. ed. Campinas: ITAL, 1988. 224p. (Série frutas tropicais, 6).

MERCADO- SILVA, E.; BAUTISTA, P.B.; GARCIA-VELASCO, M.A. Fruit development, harvest index ripening changes of guavas produced in central Mexico. Postharvest Biology and Technology, v.13, n.2, p.143-150, 1998.

MOKADY, S.; COGAN, U.; LIEBERMAN, L. Stability os vitamin C in fruit and fruit blends. Journal Science Food Agricultural, v.35, p.452-456, 1984.

MOWLAH, G.; ITOO, S. Guava (Psidium guajava L.) sugar components and related enzymes at stages of fruit- development a ripening. Journal of Japanese Society of Food Science and Technology, v.29, n.8, p.472-476, 1982.

MOWLAH, G.; ITOO, S.; Changes in pectin components, ascorbic acid, pectic enzymes and cellulas activity in ripening and stored guava ( Psidium guajava L.). Journal of Japanese Society of Food Science and Techonogy, v.30, n.8, p.454-461, 1983.

MURRAY, A.; HOBSON, G.E.; SCHUCH, W.; BIRD, C. Reduced ethylene synthesis in $\mathrm{EFE}$ antisense tomatoes has differential effects on fruit ripening processes. Postharvest Biology Technology, v.2, p. 301-303, 1993.

NULTSCH, W. Botânica geral. Trad. de P.L. de Oliveira. Porto Alegre: Artes Médicas Sul, 2000. 489p.

OETIKER, J.H.; YANG, S. F. The role of ethylene in fruit ripening. Acta Horticultural, v.398, p.167-178, 1995. 
OJEDA, R, M. Utilização de ceras, fungicidas e sanitizantes na conservação de goiabas 'Pedro Sato' sob condição ambiente. Piracicaba, 2001. 57p. Dissertação (Mestrado)- Escola Superior de Agricultura "Luiz de Queiroz", Universidade de São Paulo.

OLIVEIRA, M.A. Utilização de película de mandioca como alternativa à cera comercial na conservação pós-colheita de frutos de goiaba (Psidium guajava). Piracicaba, 1996. 73p. Dissertação (Mestrado)- Escola Superior de Agricultura "Luiz de Queiroz”, Universidade de São Paulo.

OLlER, P.W.; MIN-WONG, L.; TAYLOR, L.P.; PIKE, D.A. \& THEOLOGIS, A. reversible inhibition of tomato fruit senescence by antisense RNA. Science, v.254, p.437-439, 1991.

PAIVA, M.C. Competição entre quatro cultivares e três seleções de goiabeiras em eldorado do Sul, RS. Pesquisa Agropecuária Brasileira, v.29 n.6, p. 17-922, 1994.

PAIVA, M.C.; FIORAVANÇO, J.C.; MANICA, I.: Características físicas dos frutos de quatro cultivares e duas seleções de goiabeira no $5^{0}$ ano de produção em Porto Lucena-RS. Ciência Rural, v.25, n. 2, p.209-213, 1995.

PANTÁSTICO, E.B. Postharvest physiology, handling and utilization of tropical and subtropical fruits an vegetables. Westport: AVI, 1975. $560 \mathrm{p}$.

PECH, J.C.; BALAGUÉ, C. LATCHÉ, A.; BOUZAYEN, M. Postharvest physiology of climateric fruits: recent developmentes in the biosynthesis and action of ethylene. Science des Aliments, v.14, n.1, p.3-15, 1994. 
PELLETIER, O.; BRASSARD, R. Determination of vitamin C (L- ascorbic acid and dehydroascorbic acid) in food by manual and automated photometric methods. Journal of food science, v. 42, n.6, p. 1471-1477, 1977.

PEREIRA, F.M. Cultura da goiabeira. Jaboticabal: Funep, 1995. 47p.

PEREIRA, F.M.: MARTINEZ, M. JÚNIOR. Goiabas para industrialização. Jaboticabal: UNESP, 1986. 142p.

PERYAM, D.R.; GIRARDDOT, N. F. Advanced taste method. Food Engeneiring, v.24, p.58-61, 1952.

PIVETTA, K.F.L., DURIGAN, J.F.; PEREIRA, F.M. Avaliação da conservação póscolheita, em condições ambientais, de frutos de goiabeira (Psidium guajava L.) colhidos em diferentes estádios de maturação. Revista Brasileira de Fruticultura, v.14, n.3, p.236-239, 1992.

PURVIS, A. C. The role of adaptive enzymes in carbohydrate oxidation by stressed and senescing plant tissues. Hortscience, v.32, n. 7, p.195-168, 1997.

RATHORE, D.S. Effect of season on growth and chemical composition of guava (psidium-guajavaL) fruits. Journal of horticultural science, v. 51 n.1, p. 41-47, 1976.

REYES REYES, F.G.; MARIN, M.S.; BOLANÕS, M.A de. Determinação de pectina na goiaba (Psidium guajava L.). Revista Brasileira de Tecnologia, v.7, n.3, p.313315, 1976. 
REYES, M.U.; PAULL, R.E. Effect of storage temperature and ethylene treatment on guava (Psidium guajava L.) fruit ripening. Postharvest Biology and Technology, v.6, p.37-365, 1995.

RHODES, M.J.C. The maturation and ripening of fruits. In:THIMANN, K.V.; ADELMAN, R. C.; ROTH, G. S. Senescence in plants. Florida: CRC Press, 1980. cap.8, p.157-205.

ROMANI, R. J. Respiration, ethylene, senescence, and homeostasis in an integrated view of postharvest life. Canadian journal of botany. v.62, n.12, p.2950- 2955, 1984.

ROMANI, R. J. Senescence and Homeostasis in Postharvest research. HortScience, v.22, n.5, p.865-868, 1987.

SEREK, M., SISLER, E.C.; REID, M.S. Novel gaseous ehthylene binding inhibitor prevents ethylene effects in poted flowering plants. Journal of the American Society for Horticultural Science, v.119, n.6, p.1230-1233, 1994.

SEYMOUR, G.B.; TAYLOR, J.E.; TUCKER, G. A. Biochemestry of fruit ripening. London: Chapmal \& Hall, 1993. 454 p.

SISLER, E. C.; SEREK, M. Inhibitors of ethylene responses in plants at the receptor level: recent developments. Physiologia plantarun., v.100, p.577-582, 1997.

SMIRNOFF, N.; CONKLIN, P.; LOEWUS, F.A. Biosynthesis of ascorbic acid in plants: A renaissance. Annual Review of Plant and Physiology and Plant Molecular Biology, v.52 p. 437-467, 2001. 
TAIZ, L.; ZEIGER, E. Plant physiology, 2.ed.. Massachusetts: Beinjamin/Cummings, 1998. cap. 22, p. 651-688: Ethylene.

TEAOTIA, S.S., TRIPATHI,R.S.; BHAN,S. Evaluation of indices for determination of maturity of guava (Psidium guajava) Horticulaturae, Advance, v.7, p. 99-107, 1970 .

TRIPATHI, R.S.; GANGWAR, B.M. Biochemeical chabges as indices of maturity in guava (Psidium guajava L.) Progressive Horticulturae, v.3, n. 1, p. 17-23, 1971.

TUCKER, G.A. Introduction. In:SEYMOUR, G.B.; TAYLOR, J.E.; TUCKER, G. A. Biochemestry of fruit ripening. London: Chapmal \& Hall, 1993. cap.1, p. 2-51.

VAZQUEZ-OCHOA, R.I.; COLINAS-LEON, M.T. Changes in guavas of three maturity stages in response to temperature and relative humidity. Horticultural Science, v.25, n.1, p. 86-87, 1990.

VENDRELL, M.; PALOMER, X. Hormonal control of fruti ripening in climateric fruits. Acta horticulturae, n.463. p.325-334, 1997.

WATADA, A.E.; HERNER, R.C.; KADER, A.A.; ROMANI, R.J.; STABY, G.L. Terminology for the description of developmental stages of horticultural crops. HortScience, v. 19, n.1, p.20-21, 1984.

WILLS, R.; McGLASSON, B.; GRAHAM, D.; JOYCE, D. Introducción a la físiología y manipulación poscosecha de frutas, hortalizas y plantas ornamentales. Trad. de J.B. Gonzáles. 2.ed. Zaragoza: Acribia, 1998. 240p. . 
WILLS, R.H.H.; LEE, T.H.; GRAHAM, W.B.; HALL, E.G. Postharvest- an introduction to the physiology and handling of fruit and vegetables. Kensington: New South Wales University Press, 1981, 161p.

XISTO, A.L.R.P. Conservação pós-colheita de goiaba 'Pedro Sato'com aplicação de cloreto de cálcio em condições ambiente. Lavras, 2002. 47p. Dissertação (Mestrado).-Universidade Federal de Lavras.

YANG, S. F. Biosynthesis and action of ethylene. HortScience, v.20, n.1, Feb 1985 p.41-45.

YANG, S.F.; LIU, Y.; LAU, O.L. Regulation of ethylene biosynthesis in ripening apple fruit. Acta horticultural, n.179, p. 711-720, 1986.

YEN, H.C.; LEE, S.; TRANKSLEY, S.D.; LANAHAN, M.B.; KLEE, H.J.; GIOVANNONI, J.J. The tomato never-ripe locus regulates ethylene inducible gene expression and is linked to a homolog of the Arabidopsis ETR1 gene. Plant Physiology, v. 107, 1343-1353, 1995. 
APÊNDICE 1 
Figura 1 Ficha de avaliação e escalas de notas utilizadas para análise sensorial de goiabas.

\section{FICHA DE AVALIAÇÃO PARA ANÁLISE SENSORIAL DE GOIABAS}

Trabalho integrante do projeto de dissertação de mestrado.

Nome

data:

Por favor, prove a amostra e avalie de acordo com a escala abaixo.

\begin{tabular}{|c|c|c|c|c|c|c|c|}
\hline Variáveis & $\begin{array}{c}\text { (1) } \\
\text { Péssima }\end{array}$ & $\begin{array}{c}\text { (2) } \\
\text { Muito } \\
\text { Ruim }\end{array}$ & $\begin{array}{c}\text { (3) } \\
\text { Ruim }\end{array}$ & $\begin{array}{c}\text { (4) } \\
\text { Regular }\end{array}$ & $\begin{array}{l}\text { (5) } \\
\text { Boa }\end{array}$ & $\begin{array}{c}\text { (6) } \\
\text { Muito } \\
\text { Boa }\end{array}$ & $\begin{array}{c}\text { (7) } \\
\text { Ótima }\end{array}$ \\
\hline Odor & & & & & & & \\
\hline Sabor & & & & & & & \\
\hline Textura & & & & & & & \\
\hline Aparência & & & & & & & \\
\hline $\begin{array}{l}\text { Qualidade } \\
\text { global }\end{array}$ & & & & & & & \\
\hline
\end{tabular}

- Comentários:

O que mais gostou? (Por que?)

O que menos gostou? (Por que?) 
Tabela 1. Influência dos estádios de maturação na qualidade pós-colheita de goiabas 'Pedro Sato'.

\begin{tabular}{lcccccc}
\cline { 3 - 6 } & & \multicolumn{5}{c}{ Atributos avaliados* } \\
Estádios de & $\begin{array}{c}\text { Dias após } \\
\text { maturação** }\end{array}$ & Odor & Sabor & Textura & Aparência & $\begin{array}{c}\text { Qualidade } \\
\text { a colheita }\end{array}$ \\
\hline Estádio 1 & 6 & $5,37 \mathrm{a}$ & $4,75 \mathrm{a}$ & $4,55 \mathrm{a}$ & $4,70 \mathrm{a}$ & $4,52 \mathrm{a}$ \\
Estádio 2 & 4 & $5,57 \mathrm{a}$ & $5,07 \mathrm{a}$ & $4,85 \mathrm{a}$ & $5,30 \mathrm{~b}$ & $5,30 \mathrm{~b}$ \\
Estádio 3 & 2 & $5,87 \mathrm{a}$ & $5,80 \mathrm{~b}$ & $5,55 \mathrm{~b}$ & $5,57 \mathrm{~b}$ & $5,55 \mathrm{~b}$ \\
\hline CV (\%) & - & 18,01 & 20,2 & 17,9 & 18,15 & 17,7 \\
DMS (5\%) & - & 0,54 & 0,56 & 0,47 & 0,50 & 0,48
\end{tabular}

Médias seguidas de mesma letra, na coluna, não diferem entre si pelo teste de Tukey ao nível de $5 \%$ de probabilidade.

*Escala de notas: 1 = péssimo; $2=$ muito ruim; $3=$ ruim; $4=$ regular; $5=$ bom; $6=$ muito bom; 7 = ótimo.

** Estádios de maturação 1, 2 e 3, frutos colhidos com a cor da casca verde- escura, verde-clara e verde-amarela, respectivamente. 